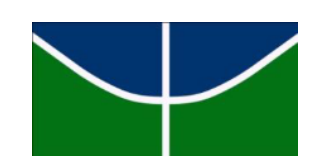

UNIVERSIDADE DE BRASÍLIA

FACULDADE DE EDUCAÇÃO

PROGRAMA DE PÓS-GRADUAÇÃO EM EDUCAÇÃO

Valdiceia Tavares dos Santos

SUBJETIVIDADE E PROCESSOS DE COMUNICAÇÃO DE DOIS JOVENS SURDOS ESTUDANTES DA SEDF

Brasília - DF

2016 
VALDICEIA TAVARES DOS SANTOS

\title{
SUBJETIVIDADE E PROCESSOS DE COMUNICAÇÃO DE DOIS JOVENS SURDOS ESTUDANTES DA SEDF
}

\begin{abstract}
Dissertação apresentada ao Programa de PósGraduação da Faculdade de Educação da Universidade de Brasília - UnB como exigência parcial para obtenção do grau de Mestre em Educação.
\end{abstract}

Orientadora: Profa. Dra. Cristina Massot Madeira Coelho

$$
\text { Brasília - DF }
$$




\title{
SUBJETIVIDADE E PROCESSOS DE COMUNICAÇÃO DE DOIS JOVENS SURDOS ESTUDANTES DA SEDF
}

\author{
Dissertação apresentada ao Programa de Pós- \\ Graduação da Faculdade de Educação da \\ Universidade de Brasília - UnB como exigência \\ parcial para obtenção do grau de Mestre em \\ Educação.
}

Aprovado em 12 de abril de 2016

BANCA EXAMINADORA

\section{Prof $^{\text {a }}$ Dr ${ }^{\text {a }}$ Cristina Massot Madeira Coelho - Orientadora}

Universidade de Brasília - Faculdade de Educação

\section{Prof $^{\mathrm{a}}$ Dr $^{\mathrm{a}}$ Celeste Azulay Kelman - Examinadora Externa \\ Universidade Federal do Rio de Janeiro}

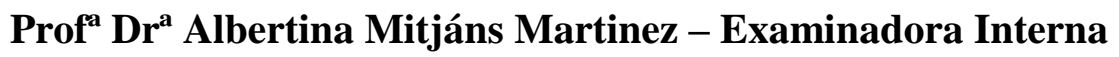

Universidade de Brasília - Faculdade de Educação

Prof $^{a}$ Dra Maria Carmen Villela Rosa Tacca - Examinador Suplente

Universidade de Brasília - Faculdade de Educação

Suplente 
Menina-Nina neta de escravos-guerreiros. Seguiu o lema de teu povo: "Nenhuma gota de seu teu sangue jorrarás sem que apresentes resistência!!!". Menina inteligente, apaixonada pelo conhecimento. Reagiu ao ver o próprio sangue após apanhar de professora. Ah! Menina-Nina, criança subversiva, não tem espaço na escola.

Menina-Nina foi expulsa da escola e chorou.

Não chora menina-Nina, a vida te reserva um Indiozinho-corredor. Irão se apaixonar, desbravar e ajudar a construir a chamada capital do país. Você há de ler muitos livros. A escola que te expulsa não controlará as reverberações de tal ato. Você educará dentre outros, três lindas meninas: uma encantadora de bebês, uma que utilizará histórias magicamente curadoras para crianças e outra que falará com as mãos. Não chora menina-

Nina. Veja o que te espera!

Ora, que ignorância a minha. Falar sobre futuro para acalentar uma menina. Não serei eu mais uma a silenciar o choro triste das meninas-Ninas.

Chora menina-Nina. Quem sabe teu choro se une ao das meninas negras, pobres, surdas e me acorda para lutar por uma escola que tenha espaço para o singular! Chora menina-

Nina! Quero fazer parte daqueles que construirão uma escola em que as meninas-Ninas serão apreciadas por não se assujeitarem! 


\section{AGRADECIMENTOS}

Ao Deus de propósitos. Ele me permitiu desejar e me habilitou para realizar o desejo que há muito habitava meu coração.

À minha equipe de filhas, Rebeca, Ana Clara, Mariana e Milena. A existência de vocês suscita em mim processos de desenvolvimento.

Aos meus familiares pai, mãe, irmãos e sobrinhos por todas as dicas e apoio e por serem companheiros e provocadores de produções subjetivas ao longo de minha história.

Ao Victor Felipe, o menino-cigarra, que resolveu cantar em árvores distantes de nós. Obrigada por ter permanecido em nossas vidas durante oito anos e por ter tornado mais feliz esse período.

Ao Nilson pela parceria, companhia e por tudo que ainda viveremos.

À Cris, minha orientadora, que em nossos processos comunicativos para além da leveza das palavras mantinha uma comunicação desenvolvedora. Aquela que intencionalmente se constitui nas relações de confiança na capacidade do outro. A comunicação desenvolvedora, só é possível quando se conhece o outro e exercita a alteridade. Ela, mesmo conhecendo minhas limitações, fragilidades e percurso histórico, nunca optou pela comunicação assujeitadora, comum aqueles que se consideram em um patamar superior ao outro. Ainda que o assujeitamento não fosse uma escolha adotada por mim durante o processo de desenvolvimento que é o Mestrado, a comunicação desenvolvedora de Cris me acompanhava nos momentos de produção solitária. Afinal, havia alguém que me conhecendo acreditava em mim e essa credibilidade foi minha companheira. Para além do trabalho acadêmico, Cris foi minha conselheira, fonoaudióloga e psicóloga em assuntos maternos.

A todos aqueles que, ao longo de minha história, também construíram comigo a comunicação desenvolvedora, minha primeira professora e diretora Íris de Jesus Câmara, papai, Stelinha e Tetê.

Especialmente à amiga Linair pelo exemplo, garra, determinação e por me incentivar, apoiar e acolher quando o único processo de comunicação que eu usava eram as lágrimas. Por corroborar através de ações com o versículo de que há amigos que são mais que irmãos.

As amigas Deila, Gilmara e Rosana Cipriano pelas risadas, leituras, compartilhamentos e por trazerem leveza ao percurso.

Aos companheiros de corrida da equipe Lo-rã e do deepwaterrunning que compartilharam comigo trilhas ou corridas no meio aquático, algumas ideias se organizaram nesses momentos. 
A todos os professores do Programa de Pós-Graduação da Faculdade de Educação. Em especial as professoras Carmen Tacca e Silvia Ester Orrú por provocarem o desenvolvimento de minhas concepções para as potencialidades das pessoas com desenvolvimento atípico e à professora Albertina Mitjáns Martinez por todo o carinho, apoio e por suas aulas inquietantes.

Aos membros da banca de qualificação, professora Carmen Tacca e Celeste Azulay Kelman, essa tem contribuído com a investigação desde o momento da qualificação, com sugestões, discussões e questionamentos.

À família Madeira-Coelho: Rê e Débora que auxiliaram na constituição de meu papel como pesquisadora. À Tamine e Carol Velho pelas trocas, risadas e compartilhamentos. Nossos pensamentos e percursos diferenciados me fizeram refletir sobre minhas posições educacionais. Claudemir por caminhar no mesmo campo e por todas as contribuições interpretativas. Também agradeço as irmãs mais novas: Erika, Karine e Luana.

Aos colegas do grupo de pesquisa Daniel Goulart, Marília, José Fernando, Eduardo Moncayo, Raquel, Elias e Gisele, nossas discussões foram sempre provocadoras.

Às queridas Rose e Socorro pelo grupo de estudos, discussões, técnicas de estudo e leituras compartilhadas.

Ao grupo de Tradutores e Intérpretes de Língua de Sinais- TILPs católicos, por todas as vivências e orações.

Aos profissionais da Escola Bilíngue pelo carinho, respeito, acolhimento e disposição em contribuir com esse trabalho e pelo anseio de construir uma escola pública de qualidade.

A todos os amigos e alunos Surdos pelas trocas comunicativas e de produção de sentido.

Aos homens e mulheres trabalhadoras que nem me conhecem, tampouco ousam sonhar com a vida acadêmica, porém, custearam minha licença remunerada para estudos e a formação em universidade pública.

Aos queridos colaboradores dessa pesquisa por estarem abertos e pelo espaço relacional que construímos.

E não menos importante, agradeço a todos aqueles que construíram comigo uma comunicação assujeitador. A tensão dessas relações e da percepção desses olhares, falas e ações me desafiaram e impulsionaram nesta trajetória. 


\section{RESUMO}

Neste estudo buscou-se compreender elementos das configurações subjetivas de dois jovens surdos e o modo como subjetivaram seus processos comunicativos em diferentes ambientes. O principal autor utilizado na pesquisa é González Rey que, em sua Teoria da Subjetividade na perspectiva histórico-cultural, afiança que a subjetividade se organiza em um sistema de sentidos singulares em cada indivíduo. Esta pesquisa foi realizada com dois estudantes do ensino médio, falantes da Língua Brasileira de Sinais entre 2014 e 2015. Trata-se de uma investigação desenvolvida com a intenção de produzir inteligibilidade sobre processos comunicativos subjetivados nas diferentes situações relacionais dos contextos escolares em que os dois estudantes se envolviam. A metodologia utilizada para a produção do conhecimento é a Epistemologia Qualitativa de González Rey que possui caráter construtivo-interpretativo em que é delegado ao pesquisador a função de produtor de conhecimento. A pesquisa levou à construção de que momentos de tensão presentes em processos comunicativos vividos por surdos são favoráveis à produção de sentidos subjetivos que se configuram e participam de outras configurações da ação das pessoas surdas. Considera-se esta pesquisa como relevante pois: poderá contribuir para a reflexão sobre os processos de subjetivação de Surdos com possibilidade de reverberar em mudança no olhar sobre a aprendizagem desses estudantes e na organização criativa do trabalho docente; para minimizar uma lacuna na produção acadêmica que contemple os aspectos subjetivos dos Surdos; facilitar o enriquecimento de políticas públicas relacionados à pratica de educação bilíngue e permitir a reflexão sobre aspectos subjetivos de escolas para surdos.

Palavras-chave: Surdos. Subjetividade. Processos de comunicação. 


\begin{abstract}
The present study sought to comprehend subjective configuration elements of the two deaf young boys and the way in which the communication processes were subjectified by them in different spaces. The main author used this research is Gonzaléz Rey, who in his Subjectivety Theory in the historical-cultural perspective assures that subjectivity is organized in a system of singular meanings in each individual. This research was performed with two students from High School, speakers of Brazilian Sign Language between 2014 and 2015. It is a research developed with the intention of producing intelligibility about communicative subjectified processes in different relational situations in school contexts in which the two students were engaged. The methodology used for the production of knowledge is the Qualitative Epistemology of González Rey, which has constructive-interpretative character, and delegates to the researcher the role of producing this knowledge. The survey revealed that of moments of tension in the communicative process experieed by deaf are favorable to the production of subjective meanings that are configured and participe of other settings of the deaf people action.This research is considered as relevant because it may contribute to the reflection about the subjective processes of the deaf students, with the possibility producing a change of view regarding the learning process of these students and the creative organization of teaching. Thus, it will help to minimize a gap in academic research that addresses the subjective aspects of the Deaf, it will facilitate the enrichment of public policies related to the practice of bilingual education and will allow reflection about subjective aspects of schools for deaf.
\end{abstract}

Key words: Deafness. Subjectivity. Communication process. 


\section{LISTA DE ILUSTRAÇÃO}

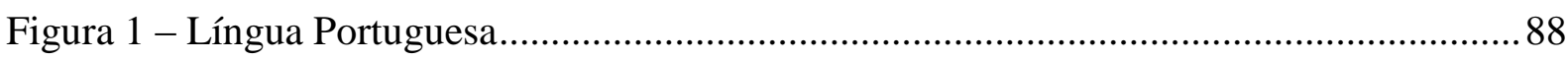

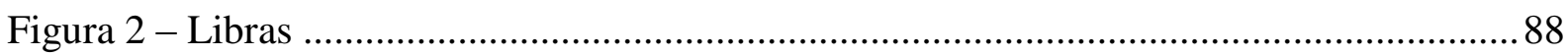

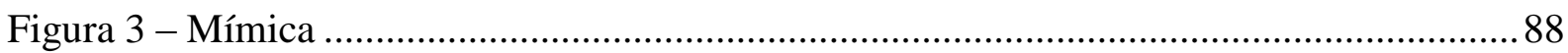

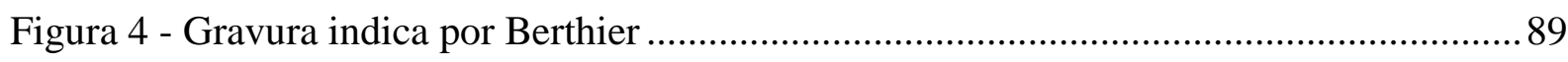

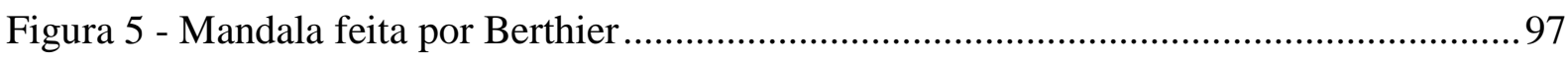

Figura 6 - Gravura escolhida por Vanessa para representar escola ...................................... 107

Figura 7 - Gravura escolhida por Vanessa para representar a irmã ...................................... 109

Figura 8 - Gravura escolhida por Vanessa para representar família ..................................... 110 


\section{LISTA DE QUADROS}

Quadro 1 - Quantitativo de estudantes da Escola Bilíngue .................................................59

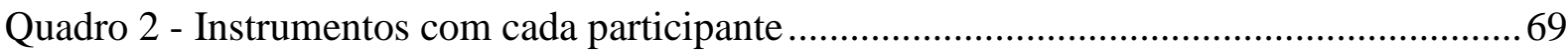

Quadro 3 - Sessões de observação ou encontro com os sujeitos da pesquisa ........................ 138 


\section{LISTA DE ABREVIAÇÕES E SIGLAS}

AEE

APADA

CODA

EB

FENEIS

ICEP BRASIL

\section{LIBRAS}

LS

PAS

PPP

SEDF

SUVAG

TCLE

TICs

TILSP
Atendimento Educacional Especializado

Associação de Pais e Amigos do Deficiente Auditivo

Children of the Deaf Adults

Escola Bilíngue

Federação Nacional de Educação de Integração dos Surdos

Instituto Cultural, Educacional e Profissionalizante e Pessoas com Deficiência do Brasil

Língua Brasileira de Sinais

Língua de Sinais

Programa de Avaliação Seriada

Projeto Político Pedagógico

Secretaria de Educação do Distrito Federal

Sistema Universal Verbo-Tonal de Audição Guberina

Termo de Consentimento Livre e Esclarecido

Tecnologias de Informação e Comunicação

Tradutores e Intérpretes de Língua de Sinais e Língua Portuguesa 


\section{SUMÁRIO}

CONSIDERAÇÕES INICIAIS .............................................................................................. 14

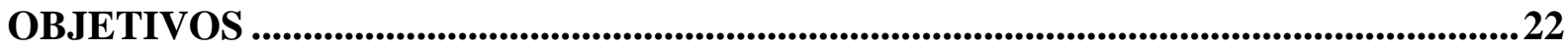

1 TEORIA DA SUBJETIVIDADE NA PERSPECTIVA HISTÓRICO-CULTURAL

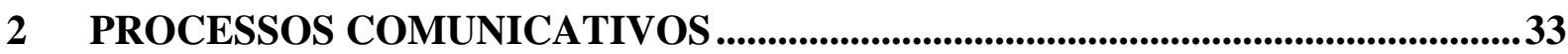

2.1 Comunicação na perspectiva da linguística ........................................................ 34

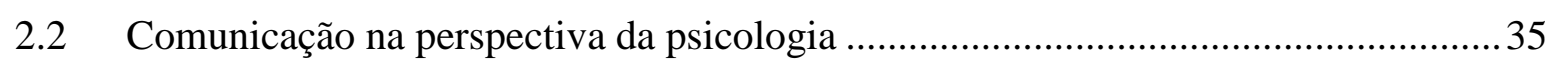

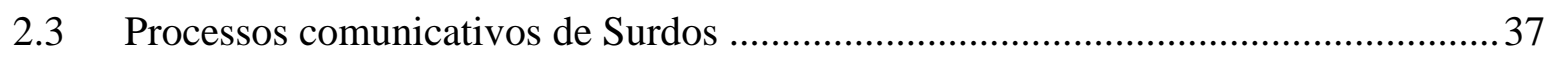

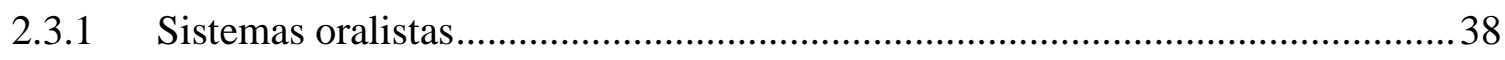

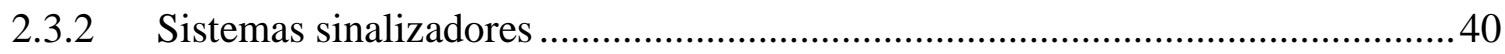

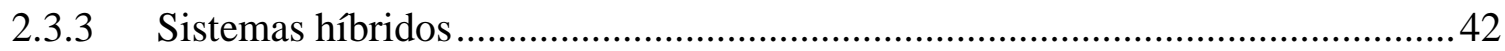

2.3.4 Processos comunicativos e o uso das tecnologias ........................................... 43

2.3.5 Comunicação de surdos como processo complexo ......................................... 45

3 CAMINHOS EPISTEMOLÓGICOS E METODOLÓGICOS ....................................53

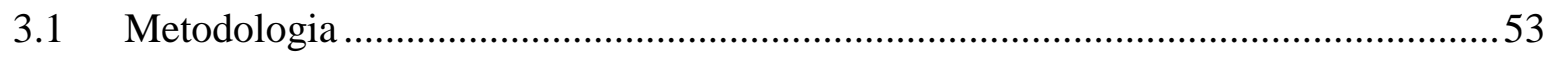

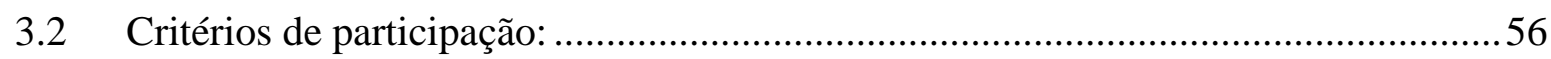

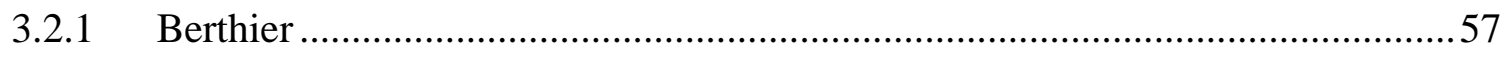

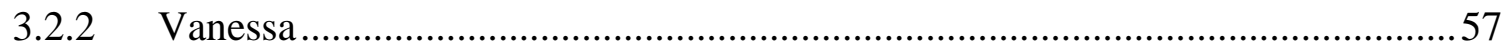

3.3 Local de pesquisa - Escola Bilíngue Libras português escrito .................................57

3.3.1 Contextualizando a Escola Bilíngue no momento histórico da educação do

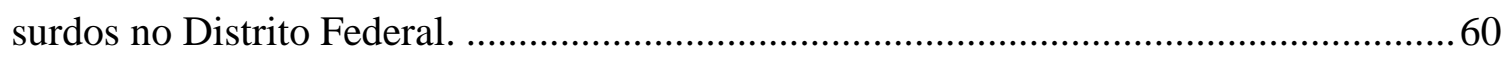

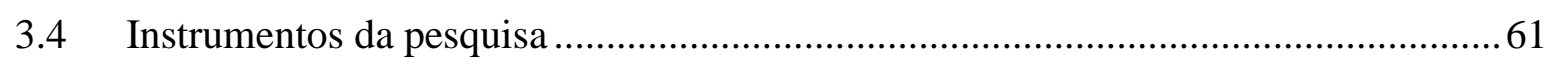

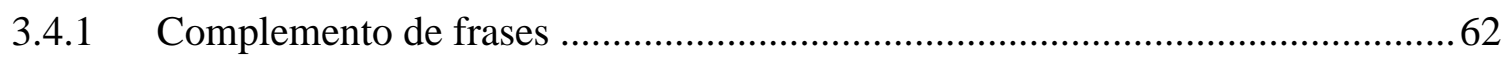

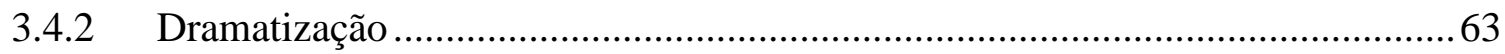

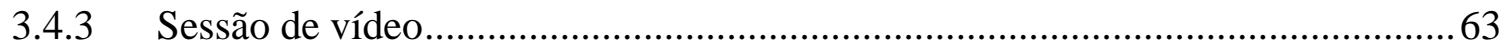

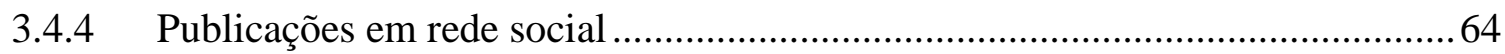

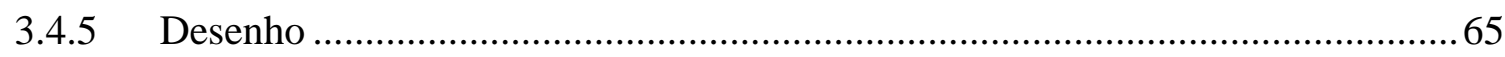

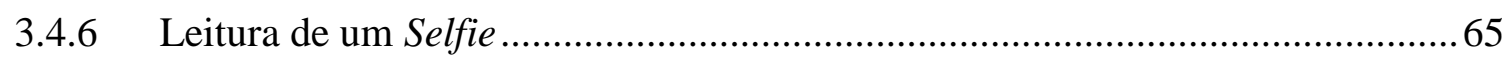

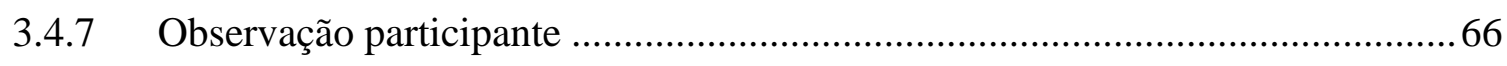

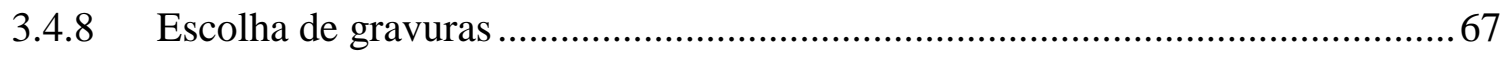

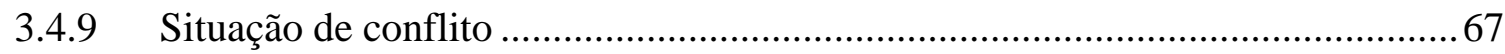




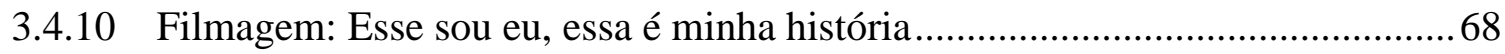

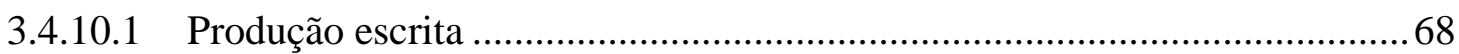

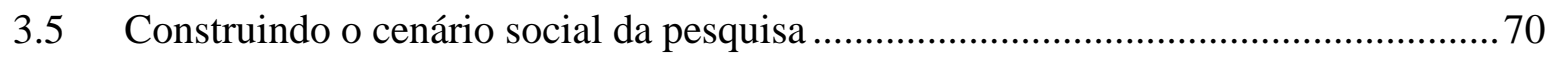

3.6 Metodologia da construção da informação................................................................72

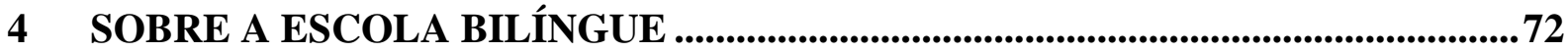

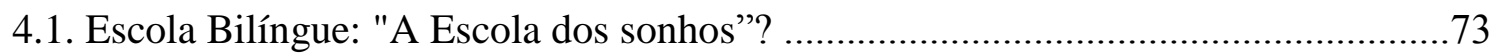

4.2. Escola Bilíngue: espaço privilegiado para o desenvolvimento da linguagem............76

4.3. Escola Bilíngue: Espaço de acolhimento para a diversidade da surdez.....................79

4.4. Escola Bilíngue no contexto da educação do Distrito Federal ...................................83

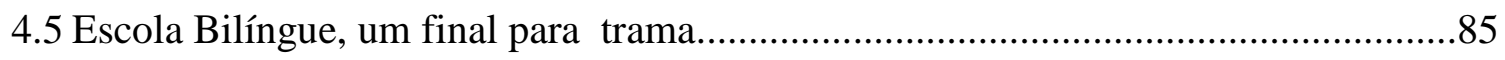

5 OS ESTUDOS DE CASO BERTHIER E VANESSA.............................................87

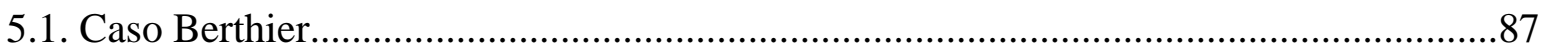

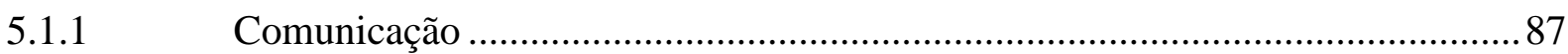

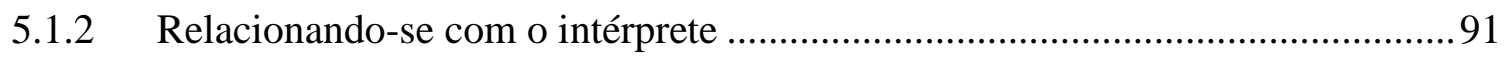

5.1.3 A família como constituinte de diversas configurações subjetivas .....................94

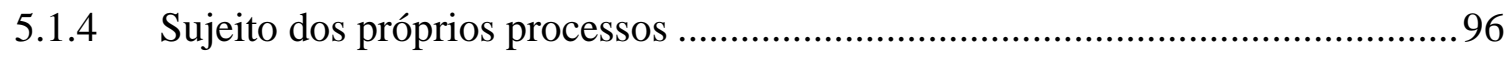

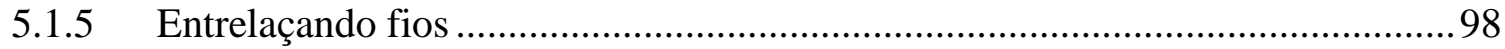

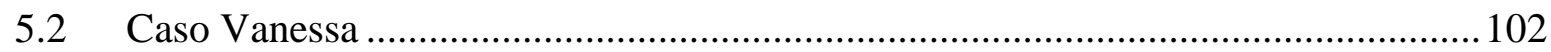

5.2.1 Eu preciso pertencer: fazendo parte de um grupo de amigos .......................... 104

5.2.2 Meu verdadeiro divã, a intérprete educacional.............................................. 105

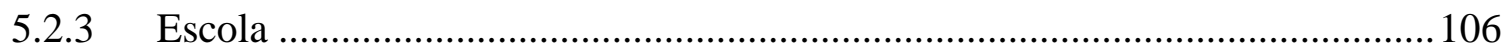

5.2.4 Família: lugar de segregação ....................................................................... 109

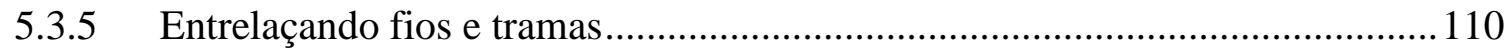

5.4 A relação de Berthier e Vanessa .............................................................................. 111

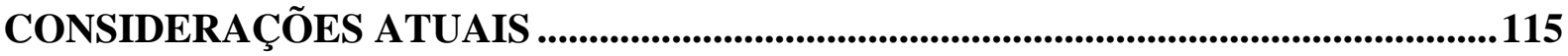

APÊNDICE I - COMPLEMENTO DE FRASES PARA O ALUNO: ................................ 130

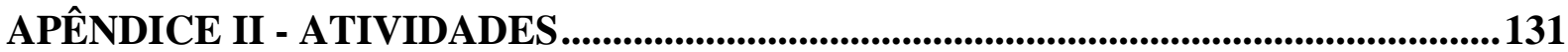

APÊNDICE IV - SESSÕES DE OBSERVAÇÃO ........................................................... 138 


\section{CONSIDERAÇÕES INICIAIS}

A busca por um modelo hegemônico de proposta metodológica de ensino e da língua mais adequada para a comunicação marca a educação de surdos, cujos primeiros registros datam da Idade Média. Nesse período, os educadores adotavam metodologias para o desenvolvimento da língua oral e as crianças surdas eram submetidas à estimulação da fala, que, de acordo com a classificação de Skliar (1998a) correspondia ao modelo clínico terapêutico da surdez, deste modo, as crianças surdas eram tratadas como pacientes. $\mathrm{O}$ ensino da escrita era introduzido somente após o aprendizado da língua oral pelos estudantes surdos. O que nem sempre acontecia. Nesses casos, não eram oportunizadas situações favoráveis ao desenvolvimento da língua escrita, mantendo as crianças surdas apartadas de uma comunicação efetiva.

Esses métodos que priorizavam a fala se mantiveram durante longo período, como uma transferência do modelo clínico-terapêutico para o espaço educacional. Desse modo, as escolas eram como clínicas e as crianças surdas pacientes a serem "reabilitados" (SKLIAR, 1998a). O processo de reabilitação manteve-se como única alternativa educacional registrada até o século XVIII, quando, aos poucos, os gestos, a fala e a escrita foram compondo as metodologias de trabalho educacional com as pessoas surdas (GUARINELLO, 2007).

No século XVIII, Abade L’Epée criou os chamados "sinais metódicos", que mantinham a estimulação da fala e utilizavam língua de sinais tornando-a mais próxima da língua oral francesa (MARTINS, 2012). A partir das primeiras iniciativas de adoção dos sinais, desencadearam-se também as controvérsias sobre seu uso na educação de pessoas surdas ou o uso exclusivo de línguas orais. Ainda assim, foi criado o "Instituto Nacional para Surdos-Mudos de Paris", primeira escola pública para surdos que adotava os sinais metódicos como metodologia de ensino. A criação dessa escola marcou o período de um salto qualitativo nesse campo da educação. Uma vez que o tempo até então dedicado exclusivamente ao aprendizado da língua oral passou a ser ocupado por um currículo mais abrangente (LACERDA, 1998).

Os resultados da escola de Paris foram propagados e os professores surdos ali formados foram responsáveis pela abertura de novas escolas especiais, que seguiram o mesmo modelo.

Em contrapartida, o movimento em defesa do oralismo puro como metodologia para educação de surdos teve seu apogeu no Congresso Internacional de Surdo-Mudez ${ }^{1}$ que ocorreu em Milão na Itália, em 1880. A participação dos surdos foi restringida nesse Congresso, eles

\footnotetext{
${ }^{1} \mathrm{O}$ termo surdo-mudo era adotado na época, mas, atualmente, na perspectiva linguístico-cultural adota-se apenas o termo surdo.
} 
foram impedidos de participar das votações decisivas. No Congresso, ficou decidido que o oralismo puro, que consistia no uso exclusivo da língua oral, seria a única metodologia aceita para educação dos surdos (INES, 2011).

As decisões do Congresso de Milão permaneceram durante quase 100 anos e tiveram como consequência o fechamento das escolas para surdo, a demissão dos professores surdos e a volta ao uso exclusivo da metodologia oral.

As situações de tensão pela proibição das línguas de sinais produziram a resistência em grupos de Surdos, de modo que as línguas de sinais foram mantidas clandestinamente. Os grupos de Surdos que não se assujeitaram a essa proibição organizaram clubes e associações. Esses espaços serviram para o enfrentamento de outros coletivos e para luta pelo reconhecimento das línguas de sinais bem como seu retorno aos espaços educacionais. As escolas de surdos, de modo clandestino, também serviram para preservação das línguas de sinais (STROBEL, 2009, 2012).

Apenas em 1960, com o resultado das pesquisas de Stokoe (1960), passou a ser reconhecido o status de língua para as línguas de sinais, já que ficou demonstrado que essas possuem todos os níveis de análise que as definem como língua. Assim, reiniciou-se o retorno oficial das línguas de sinais para os espaços educacionais.

Posteriormente, ao final dos anos de 1970, com a eclosão dos movimentos sociais de valorização linguística pelas minorias, especialmente nos Estados Unidos, as comunidades surdas fortaleceram-se na defesa das línguas de sinais e dos seus valores (GUARINELLO, 2007).

Aos poucos, cresceram as pesquisas de antropólogos, linguistas e sociólogos que tratavam das pessoas surdas, criando o movimento socioantropológico, que define o Surdo como pertencente a uma comunidade linguística e cultural que interage com o mundo por meio de uma experiência visual (SKLIAR, 1998b).

A rivalidade dos grupos de educadores e pesquisadores, desde o Congresso de Milão dividiu os surdos sinalizadores dos surdos oralizados ou com a expectativa de oralização. A escolha linguística adotada para comunicação passou a classificar os surdos em categorias. Desse modo, os surdos sinalizadores e surdos oralizados se dividiram em grupos rivais. Essa dicotomia entre a perspectiva clínico-terapêutica e linguístico-cultural persiste na contemporaneidade.

Os movimentos surdos na modernidade têm exigido a implantação de um modelo de educação bilíngue, onde a língua de sinais é a língua de instrução e o caminho que possibilita o acesso à língua oficial do país. Na educação bilíngue proposta pela comunidade Surda, a língua 
de sinais é a primeira língua e a língua escrita do país a segunda língua a ser ensinada para as crianças surdas. Para tanto, é defendida a presença dos professores surdos como modelo de identidade e para o ensino da língua de sinais. Uma das defesas por esse modelo de educação vem das pesquisas que apontam como motivo do fracasso escolar a falta de convívio com outros surdos para trocas linguísticas o que implica numa aquisição de língua de sinais tardia (DORZIAT, 2009; STRÖBEL, 2012).

Bisol e Sperb (2010) postulam que historicamente a produção sobre surdez pode ser dividida nos temas de enfretamentos e conquistas: ao final da década de 1960, as línguas de sinais adquiriram o status de língua; a década de 1970 marcou o momento de enfrentamento pelo reconhecimento da cultura com direito a uma política e educação próprias; nos anos de 1980 e início dos anos de 1990 houve a necessidade de postular a identidade Surda, que é uma chamada ao sujeito ativo, que naquele momento da produção constituiu-se em modelos de identidade. Já na segunda metade desse período, começam as reflexões sobre a complexidade do Surdo em suas relações sociais, impulsionados por estudos sobre multiculturalismo e biculturalismo. Segundo os autores, surge um novo olhar sobre os Surdos como um modelo sociocultural, modelo cultural ou modelo pós-cultural, com contribuições da psicanálise e das narrativas para um olhar da complexidade da surdez, perspectiva com a qual este trabalho também pretende contribuir com o enfoque da complexidade, porém baseado na Teoria da Subjetividade na perspectiva histórico-cultural de González Rey.

Partindo desses pressupostos históricos, chegamos ao momento atual em que este trabalho se organiza em torno da compreensão de elementos das configurações subjetivas de dois jovens surdos e o modo como subjetivaram os processos comunicativos vividos em diversos espaços sociais. Não há como tratar da pesquisa sem contextualizar o percurso histórico e profissional da pesquisadora, uma vez que a pesquisa se constituiu de situações vividas e inquietações que a acompanharam em sua trajetória.

Como justificativa pessoal, essa investigação nasceu do meu encantamento pelos surdos e do compartilhamento dos processos comunicativos utilizados por eles. Minha história propiciou-me conviver, na infância, com um colega surdo. Nosso espaço de convivência era o ônibus que nos conduzia à escola. O colega surdo estava sempre acompanhado de uma professora ou de sua mãe. Portanto, a aproximação e os processos comunicativos utilizados por nós foram sempre balizados por um adulto que não permitia o uso livre da língua de sinais. Além das tentativas de fala oral trocávamos olhares e gestos discretos que não se constituam língua, mas que possuíam uma mensagem. Após essa experiência, durante muitos anos, não tive mais contatos com pessoas surdas. 
Até o momento em que, no campo profissional, me deparei com a opção do trabalho com pessoas surdas, que se constituiu na minha escolha profissional nos últimos dezessete anos. Nesse período, ouvi relatos de crianças e jovens descontentes por seus esforços unilaterais na busca pela comunicação nos espaços de socialização, em especial na família. Compartilhavam as angústias vividas nos processos de aprendizagem da língua portuguesa oral ou na criação de alternativas comunicativas, como desenhar, escrever e mostrar objetos. Em seus depoimentos, os surdos com quem convivi afirmavam não perceber a intenção comunicativa da maioria dos ouvintes.

Os relatos mencionados me permitiram refletir sobre a configuração familiar desses indivíduos. Por esse motivo, pesquisei em Especialização Lato Sensu: "Sujeito Surdo X Pais Ouvintes - Existe vínculo afetivo?" (TAVARES-SANTOS, 2004). Esse trabalho mostrou rupturas nas relações entre os colaboradores da pesquisa e familiares, pois os surdos sentiam como se não pertencessem às suas famílias. A conclusão do estudo motivou-me a pesquisar como o Surdo se estabelece nesse cenário familiar ouvinte, em especial quando há aquisição tardia da língua.

O objetivo inicial que me trouxe a esta pesquisa, foi sendo alterado à medida em que conheci produções no âmbito da surdez para verificar a real contribuição que o tema proposto poderia trazer para área. A revisão bibliográfica ${ }^{2}$, que optei por não apresentar nessa dissertação, mostrou que a produção sobre subjetividade é ainda incipiente. Paralelo ao levantamento bibliográfico, iniciei meus contatos com a Teoria da Subjetividade e me encantei com essa perspectiva que rompe com qualquer modo de apagamento do sujeito e se apresenta como a possibilidade de abrir novas zonas de inteligibilidade sobre a pessoa surda, que permitam a construção teórica sobre seu modo singular de constituição, para além das questões linguísticas.

Na linha da Teoria da Subjetividade na perspectiva histórico-cultural de González Rey cheguei aos trabalhos de Orsoni (2007) e Franco (2014). O estudo de Orsoni (2007) buscou compreender a produção de sentidos subjetivos dos pais e irmãos de Surdos e apontou para a necessidade de uma investigação dos processos subjetivos da pessoa surda oriunda de configuração familiar ouvinte. Já a pesquisa de Franco (2014), investigou sentidos subjetivos de estudantes surdos a partir de vivência do bullying.

${ }^{2}$ A revisão bibliográfica realizada foi ampla e não aparece em um capítulo específico, mas ao longo do texto foram citadas as produções que contribuíram com esse trabalho. 
Cabe esclarecer que o tema da subjetividade se mantém insignificante nos estudos das instituições educacionais, não apenas no que se refere aos estudos das pessoas surdas. Durante o Século XX, a ênfase dada aos processos de linguagem e significação e de linguagem como prática social colocou o sujeito e o subjetivo em segundo plano (GONZÁLEZ REY, 2012b). Além disso, o termo subjetivo historicamente foi utilizado para se referir ao distorcido, ao espiritual, ao reflexo do externo, ao oculto sendo, dessa forma omitido, nos estudos das ciências sociais e humanas na qual se insere a temática da educação de surdos (GONZÁLEZ REY, 2012b).

Compreende-se que os processos de aprendizagem estão implicados com os processos de subjetivação das pessoas que deles participam, sendo cogente o avanço do estudo sob essa ótica. No caso deste estudo, o desejo de compreender a complexidade humana e elementos subjetivos que participam da aprendizagem de pessoas surdas, levou à opção pela Teoria da Subjetividade, na perspectiva histórico-cultural de González Rey (2002, 2005b, 2012a).

Aliado a isso, durante a construção do cenário de pesquisa que se constituiu como projeto-piloto, percebi que os rompimentos de comunicação que ocorrem com o Surdo poderiam acontecer nos diversos contextos em que vivem, como o familiar, o escolar ou o religioso, entre outros.

As considerações acima tiverem implicações significativas para a decisão de rever o objetivo da pesquisa, que passou a buscar compreender elementos das configurações subjetivas de dois jovens surdos e o modo como subjetivaram processos comunicativos em diferentes contextos e se desdobra em caracterizar e conhecer processos de comunicação utilizados por eles e compreender aspectos da subjetividade individual desses colaboradores.

A Epistemologia Qualitativa (GONZÀLEZ REY, 2002, 2005b, 2014), adotada neste trabalho, pressupõe um pesquisador ativo e embasado teoricamente na epistemologia adotada para compreender o estudo dos casos singulares. Esse estudo privilegiou a singularidade dos casos estudados, que está para além do estudo dos casos individuais, mas relaciona-se com o estudo de pessoas a partir da forma como se constituiram subjetivamente ao longo de seus percursos históricos.

Ao longo dessa investigação, utilizou-se o termo "comunidade surda". Nesse caso, a partir de Padden e Humphries (2000), em que comunidade surda são as pessoas que convivem e possuem objetivos comuns. Essas pessoas podem ser Surdos ou ouvintes, como por exemplo intérpretes, familiares de surdos, professores e amigos que buscam meios para alcançar os objetivos do grupo. 
Cabe esclarecer a tensão que envolveu a escolha entre os termos pessoa surda e sujeito surdo ao longo do texto. A categoria "sujeito" na Teoria da Subjetividade (2002, 2003, 2005a) remete à condição reflexiva, histórica e atuante da pessoa, conforme será detalhado no primeiro capítulo. Por outro lado, na perspectiva socioantropológica da surdez (SKLIAR, 1997a, 1997b, 1998a) o termo utilizado é sujeito surdo. Perlin (2014) explica que "os sujeitos surdos não são aqueles que se apresentam como deficientes auditivos, mas os sujeitos que retomam e afirmam suas diferenças como sujeitos leitores que leem as comunicações, que fazem uso dos olhos e que, de acordo com o totêmico ${ }^{3}$ se agarram aquilo que os identifica" (PERLIN , 2014, p. 223). Existe uma aproximação entre a categoria sujeito da Teoria da Subjetividade e o uso proposto por Perlin, pois ambas se referem ao sujeito ativo. Há porém um ponto de divergência, pois na Teoria da Subjetividade (2002, 2005a) a categoria sujeito não se emprega a todos os indivíduos de um grupo ou circustância. Perlin (2014) fala de um sujeito surdo reflexivo e que assume a surdez como condição, em oposição a outros surdos que se intitulariam como deficientes auditivos. Por compreender que aquele que se intitula surdo, nem sempre é sujeito dos seus processos, assim como pode ocorrer que aqueles que se denominam deficientes auditivos de modo consciente e reflexivo possam também ser sujeitos, opto pelo uso do termo Surdo quando falar de pessoa surda, como postulado por Sacks (1998) ao compreender Surdo como pertencente a um grupo linguístico e cultural e surdo com letra minúcula quando fizer referência a condição biológica, à falta de audição. Utilizo principalmente o termo pessoa surda, dado o caráter global e sistêmico que o termo agrega, considerando para além da surdez, não assujeitando o surdo aos seus processos linguísticos, mas como indivíduo complexo, com desenvolvimento singular e processual.

Inicialmente, serão apresentados os objetivos geral e seus desdobramentos. Em seguida, no primeiro capítulo, apresentarei a Teoria da Subjetividade na perspectiva histórico-cultural de González Rey, o contexto histórico de sua gênese e seu desenvolvimento que aponta um novo olhar para a pessoa surda. Ainda nesse capítulo, será apresentada a compreensão sobre o valor heurístico dessa produção para o avanço na compreensão dos processos das pessoas surdas.

\footnotetext{
${ }^{3}$ Conforme Perlin (2014), totêmico se refere à: "Ser leitor e não auditor é a referência totêmica dos surdos. Esta referência é o identificador comum, não a identidade. A ‘força ritual' e a relação dela com o 'totem' identificam a aglutinação de um grupo de pessoas em torno de um conjunto de práticas e de objetos. O totêmico pode também explicar o consumismo como efeito de um operador fortemente alçado ao processo de 'rendição' ou 'amor' aos objetos consumidos. No caso dos surdos, o objeto externo cultuado, amado e querido é o uso da visão, pois é a partir daí que surge a pulsação identitária, a cultura, a língua de sinais" (PERLIN, 2014, p. 223).
} 
O segundo capítulo apresenta de modo sucinto a visão de linguistas e psicólogos sobre processos comunicativos, sistemas de comunicação oralistas, sinalizadores e híbridos utilizados por surdos e uma reflexão sobre como processos comunicativos participam da constituição da subjetividade da pessoa em seu caráter complexo.

O terceiro capítulo se refere ao caminho metodológico: a construção do cenário de pesquisa, a caracterização dos colaboradores, os instrumentos propostos e sua forma de utilização.

O quarto capítulo se refere ás construções feitas em torno da Escola Bilíngue.

O quinto capítulo trata das construções da pesquisadora sobre a subjetividade de dois jovens surdos sujeitos dessa pesquisa. Nota-se que tanto um quanto outro colaborador viveram situações comuns e tiveram um percurso escolar semelhante. Porém a constituição subjetiva de cada um deles é singular.

Resta esclarecer, que as transcrições das expressões dos colaboradores, sempre que ocorreram em Língua de sinais foram registradas a partir dos parâmetros de Quadros e Karnopp (2004). Portanto, os enunciados em Libras foram traduzidos para Língua Portuguesa e colocados entre [COLCHETES] com letra maiúscula. A soletração manual ou [D-A-T-I-L-OL-O-G-I-A] foi marcada com palavras, entre colchetes em que as letras estão separadas por hifens. Os registros feitos (entre parênteses) se referem às expressões não-manuais que participam das línguas de sinais. As expressões não-manuais são "os movimentos da face, dos olhos, da cabeça, ou do tronco, prestam-se a dois papéis nas línguas de sinais: marcação de construções sintáticas e diferenciação de itens lexicais" (QUADROS \& KARNOPP, 2004, p. 60).

Como desdobramentos, este trabalho permite a reflexão sobre processos vivenciados em escolas para surdos e contribuir com a compreensão dos aspectos subjetivos de pessoas surdas.

Assim, neste trabalho, concebe-se a aprendizagem "como um processo essencialmente singular, pautado pela marca pessoal de cada sujeito, permitindo-lhe atribuir um caráter autobiográfico ao aprender” (ROSSATO \& MITJÁNS MARTINEZ, 2011, p. 100). Sob essa perspectiva, as pessoas são constituídas por processos subjetivamente produzidos em caráter simbólico-emocional no momento atual e os produzidos em outros momentos da sua trajetória de vida. Portanto, compreender aspectos subjetivos relacionados aos processos comunicativos dos sujeitos da pesquisa pode contribuir para a compreensão dos processos de aprendizagem desses indivíduos.

Desta forma, o trabalho busca compreender produções de sentidos subjetivos que participam também dos processos de desenvolvimento e aprendizagem. Grande parte dessa 
investigação ocorreu na única Escola Bilíngue do Distrito Federal. Um dos pontos positivos dessa investigação é que os colaboradores deste trabalho iniciaram sua vida escolar em escola com modelo oralista e durante o decorrer da pesquisa foram transferidos para Escola Bilíngue. Portanto, vivenciaram dois modelos de educação ainda vigentes no Brasil. Outro ponto de destaque é que grande parte do percurso educacional desses estudantes foi compartilhado. Como estudaram muitos anos juntos, houve a possibilidade de compreender os percursos singulares, ainda que em espaços educacionais compartilhados.

Essa pesquisa poderá ainda, subsidiar professores, pesquisadores e psicólogos no uso de instrumentos disparadores de uma comunicação efetiva, que favoreça a expressão da subjetividade das pessoas que não se comunicam pela língua portuguesa oral. 


\section{OBJETIVOS}

\section{OBJETIVO GERAL}

Compreender elementos das configurações subjetivas de dois jovens surdos e o modo como subjetivaram processos comunicativos em diferentes contextos.

\section{Objetivos específicos}

- Caracterizar e conhecer processos comunicativos utilizados por dois jovens Surdos colaboradores desta pesquisa;

- Compreender aspectos da subjetividade individual desses jovens. 


\section{TEORIA DA SUBJETIVIDADE NA PERSPECTIVA HISTÓRICO-CULTURAL}

A Teoria da Subjetividade é uma abordagem aberta e em desenvolvimento. Para compreendê-la, neste capítulo buscaremos em sua gênese o contexto histórico. Pretende-se ainda apresentar as principais categorias que em caráter sistêmico compõem a Teoria da Subjetividade. Para melhor elucidar, cada vez que iniciar a explanação de uma categoria, essa será destacada em negrito. Porém, devido ao caráter sistêmico dessa teoria, quando estiver tratando de uma categoria podem ser citadas outras que se inter-relacionam e se nutrem mutuamente.

Historicamente, após a Revolução de Outubro, a psicologia na União Soviética - URSS foi repensada sob uma matriz histórico-dialética. Assim, incentivaram-se as produções no campo da psicologia baseadas no materialismo histórico-dialético de Marx e Engels, como forma de legitimar os ideais de uma política absolutista. Nesse contexto, a abordagem históricocultural se desenvolveu como uma parte da psicologia que, ao investigar processos psíquicos, confere à constituição dos indivíduos um caráter dialético que reúne aspectos históricos e atuais, sociais e individuais (GONZÁLEZ REY, 2003).

As discussões e investigações sob a perspectiva histórico-cultural foram alavancadas, principalmente, pelas produções da "troika", composta por A. R. Luria, A. N. Leontiev e L. S. Vigotsky.

A partir da obra de Marx, Vigotsky foi um dos expoentes dessa abordagem. Ele e, posteriormente, Rubistein, concebiam a $p$ sique $^{4}$ de maneira distinta do modelo então vigente. González Rey (2012a) afirma que para a psicologia tradicional a psique era compreendida como decorrência imediata da organização socioeconômica e política da sociedade. Vigotsky, assim como Rubistein, rompe com essa visão reducionista e mecanicista ao conceber a psique em seu aspecto complexo, como desenvolvimento processual e dinâmico vinculado à ação do homem em interação com o ambiente social. Rescindiam ainda com as dicotomias "afetivo-cognitivo, consciente-inconsciente, social-individual, etc" (GONZÁLEZ REY, 2005a, p. 34). Essas ideias se concretizaram no princípio da unidade entre consciência e atividade, de Rubinstein, e na categoria sentido, de Vigotsky, este em sua última etapa de produção (GONZÁLEZ REY , 2012).

As publicações de Vigotsky foram proibidas por mais de duas décadas na União Soviética. Posteriormente, as primeiras traduções - inicialmente do russo para o inglês e,

\footnotetext{
${ }^{4}$ Para González Rey a psique é compreendida como formações psíquicas em processo, em movimento (GONZÁLEZ REY, 2013).
} 
ulteriormente, do inglês para o espanhol comprometeram, significativamente, as reflexões originais (GONZÁLEZ REY, 2012a, 2012b). Segundo González Rey (2012a), as primeiras traduções contemplaram os textos em que Vigotsky enfatizava a linguagem e a cognição, por legitimar as abordagens teóricas propostas pelos investigadores no ocidente, daquela época. Considerados a censura e os problemas de tradução, no Ocidente, as obras de Vigotsky apenas se popularizaram a partir de 1980. Durante este período, haviam dentre os grupos de autores da psicologia social, dois grupos antagônicos, um que apoiava e dava seguimento às ideias de A. N. Leontiev, criador da Teoria da Atividade, e outro que o que criticava e se opunha a essa vertente (GONZÁLEZ REY, 2012a, 2012b).

González Rey pertence ao grupo antagônico à Teoria da Atividade, criticando A. N. Leontiev por adotar apenas a parte da produção em que Vigotsky priorizou o estudo das funções psíquicas superiores e os "conceitos de signo, ferramenta, mediação e interiorização" (GONZÁlEZ REY, 2012a, p. 6). Para González Rey (2012a), A. A. Leontiev desprezou o momento mais rico da produção de Vigotsky, quando esse rompe com as dicotomias entre cognição e afeto e investiga a fantasia e a imaginação.

De modo mais amplo, pode-se afirmar que González Rey (2005a) se posicionou de maneira subversiva ao modelo cartesiano e positivista de compreensão da psique humana, adotado na psicologia contemporânea, e desenvolveu estudos sobre a personalidade. A partir do mergulho do autor na psicologia social e na psicologia da saúde, o tema da personalidade avançou para um sistema mais abrangente que culminou na Teoria da Subjetividade como novo modelo teórico, epistemológico e metodológico para a compreensão da psique humana (GONZÁLEZ REY, 2005c).

De acordo com Mitjáns Martinez (2005), o modelo proposto por González Rey (2001) é considerado uma teoria por tratar-se de um paradigma sistêmico que busca compreender a psique humana como fenômeno real e por constituir-se como sistema articulado e processual. Essa perspectiva teórica adota uma ontologia própria, capaz de compreender a complexidade requerida pelo tema, e de uma epistemologia com caráter sistêmico, dialético e dialógico, na qual o pesquisador ocupe papel de destaque.

Inserida no contexto histórico-cultural, a Teoria da Subjetividade avança em relação ao conceito de sentido de Vigotsky. Sentido em Vigotsky (1997) aparece como conjunto de fatos psicológicos que surgem na mente diante de uma palavra, o autor ainda faz referência implícita à psique como uma "formação complexa, fluída, que tem inúmeras zonas que variam em sua instabilidade" (VIGOTSKY, 1997, p. 275). 
Além de forte influência de Vigotsky e da crítica à Teoria da Atividade de A. N. Leontiev, a Teoria da Subjetividade é inspirada também pela leitura dos trabalhos desenvolvidos por Freud, autor da psicanálise, G. Allport e L. I. Bozhovich, pelos trabalhos orientados por Chudnovsky e pelos autores humanistas norte-americanos. Apresenta pontos de convergência também com as obras de Moscovici, Martín Baró, além de Castoriadis e Guattari (GONZÁLEZ REY, 2003).

De acordo com Mitjáns Martinez (2005), a Teoria do Pensamento Complexo de Morin (1999), originada na filosofia, articula-se com a Teoria da Subjetividade de González Rey (2005a, 2012b), advinda do campo da psicologia.

O caráter complexo da subjetividade deve ser compreendido na base epistemológica e teórica que sustenta o termo complexo, uma vez que é recorrente a banalização do conceito, inclusive no meio acadêmico, do qual se espera uma postura mais reflexiva. $\mathrm{O}$ uso indevido do conceito leva à associação entre os termos complexo e complicado. Mitjáns Martinez (2005) a partir de Morin (1999) e Ardoino (2002) diferencia os termos: entende-se complicado "no sentido de emaranhado, difícil de compreender -, complexidade constitui um modo de compreender a realidade no qual é reconhecido o caráter desordenado, contraditório, plural, recursivo, singular, indivisível e histórico que o caracteriza" (MITJÁNS MARTINEZ, 2005, p. 4).

Diante disso, se apresenta o conceito de subjetividade, que é multidimensional e contraditória e possui características que a legitimam como expressão do paradigma da complexidade, constituindo-se como modo complexo de compreender a psique humana (MITJÁNS MARTINEZ, 2005).

Esse modo complexo constitui-se a partir da produção de sentidos subjetivos dos indivíduos e dos grupos sociais de acordo com situações vividas. Vale à pena ressaltar que os processos de subjetivação ocorrem quando a pessoa significa simbólico-emocionalmente uma experiência. Para González Rey (1997, 2005, 2012), subjetividade é tanto uma teoria quanto uma categoria. Sentido subjetivo, configuração subjetiva, sujeito, subjetividade individual e subjetividade social são categorias que se entrelaçam, se articulam, se organizam e se nutrem constituindo uma a outra em um sistema "complexo, dinâmico, integrador e impossível de ser decomposto em seus componentes elementares" (ROSSATO, MARTINS \& MITJÁNSMARTINEZ, 2014, p. 38).

A situação analisada a seguir busca favorecer a compreensão do caráter sistêmico da subjetividade e como ocorre a produção de sentidos subjetivos. 
A personagem desse relato é uma mulher surda, que ao longo de sua história já vivenciou contextos de dificuldade de comunicação em vários espaços. Certa vez, ao ser convocada para reunião na escola do filho, não compreendeu o que a professora falou e reagiu de modo agressivo. Nessa reação não está circunscrita unicamente a situação em si, mas participam desse impasse comunicativo e da agressividade manifestada, unidades simbólico-emocionais produzidas nos mais diversos campos de acordo com o modo como foram vivenciadas e subjetivados por essa mãe. Desta forma, estão envolvidas configurações subjetivas constituídas a partir de diversas ordens ao longo de sua vida, como nas suas experiências no campo escolar, financeiro, profissional, afetivo, das vivências da maternagem, da sua autovaloração como mulher, além da questão da barreira de comunicação inegavelmente ali presente. A situação poderia ser compreendida como situação típica de uma mãe surda que necessita acompanhar a vida escolar do filho e que encontra dificuldades com o uso da língua oral. No entanto, se assim considerarmos seria retirado o foco da pessoa inserida em contexto social, cultural e histórico e, portanto, singular. Nesse caso, sentidos subjetivos da mulher surda emergiram em um momento de tensão que se tornou disparador de emoções e processos simbólicos que, em um sistema de relações, foram expressos em sua ação agressiva.

\footnotetext{
O sentido subjetivo nos separa do determinismo psicológico e compreende as diferentes produções humanas dentro de contextos nos quais novos sentidos subjetivos emergem, alterando o valor subjetivo da situação e, por sua vez, modificando os sentidos subjetivos dominante no momento do início da ação, em um processo que, ao se concretizar em um ato, não é possível atribuir-lhe uma origem psicológica pontual e concreta (GONZÁLEZ REY, 2007, p. 140).
}

A situação ilustrada poderia ser compreendida, de maneira simplista, como decorrente da barreira de comunicação enfrentada na situação, considerando a existência objetiva de um rebaixamento auditivo que se impõe a essa mãe, porém uma série de sentidos subjetivos emergem na ação da mulher indicando que somente a objetividade dos fatos é insuficiente para a compreensão da comunicação das pessoas nesse contexto. $\mathrm{O}$ modo como a senhora enfrenta situações de incompreensão, o modo como a professora parece compreender a questão da surdez, ou seja, a subjetividade social em torno da surdez e de pessoas surdas participam simbólico-emocionalmente da situação.

Segundo González Rey (2005a) os sentidos subjetivos desenvolvem-se independentes dos processos simbólico-emocionais que os originaram. Nesse processo, os sentidos subjetivos afastam-se tanto de um processo desencadeador que se tornam irreconhecíveis tanto por quem os produziu quanto por seus pares. 
O caráter de desenvolvimento e da constituição do sentido subjetivo foi especificado pelo autor:

\begin{abstract}
A categoria sentido subjetivo expressa a integração entre organização e processualidade, que caracteriza o desenvolvimento dos sistemas complexos. Os sentidos subjetivos representam a unidade do emocional e do simbólico sobre uma definição produzida pela cultura (ou seja, os sentidos sempre se organizam sobre espaços simbolicamente existentes e significam, justamente, a possibilidade diferenciada da ação humana dentro de tais espaços) unidade na qual um aspecto evoca outro, sem se converter em sua causa, o que implica o fato de que a emergência de cada um deles (emoções e processos simbólicos) gere desdobramentos, que por sua vez, provoquem a emergência de novas manifestações no outro, o que define o caráter processual, mas simultaneamente sistêmico, dos sentidos subjetivos (GONZÁLEZ REY , 2007, pp. 135-136).
\end{abstract}

O autor explicita que os processos são, na mesma medida, emocionais e simbólicos, sem que um se sobreponha ao outro. Dessa forma, os sentidos subjetivos compõem as configurações subjetivas, mas não se encerram nelas, também não se concluem com sua produção, mas como sistema, flexível, contraditório e recursivo. Ressalta, ainda, o caráter indivisível de cultura e psique no desenvolvimento humano (GONZÁLEZ REY, 2006).

Sentido subjetivo é também a unidade não padronizada para compreender processos subjetivos de uma pessoa ou grupo social. Ao interpretar sentidos subjetivos de um Surdo, é possível produzir teoricamente sobre a subjetividade social da comunidade surda da qual ele participa.

Sentidos subjetivos produzidos nas diversas experiências vividas integram-se de modo mais ou menos estável, constituindo configurações subjetivas. Essas são "núcleo dinâmico de organização que se nutre de sentidos subjetivos muito diversos, procedentes de diferentes zonas da experiência social e individual" (GONZÁLEZ REY 2004b, p. 203). Portanto, há que se conceber que cada vivência é simbólico-emocionalmente significada de modo diverso em cada pessoa que a vivencia.

Nesse sentido, configurações subjetivas exercem papel de centralidade na Teoria da Subjetividade, pois integram, na ação atual, o modo de subjetivação de diversas áreas da vida da pessoa ao longo de sua história (GONZÁLEZ REY, 2005a), sendo nutridas por sentidos subjetivos produzidos nos diversos espaços de atuação da pessoa singular.

Com vistas a explicar o caráter da singularidade da subjetividade e a constituição das configurações subjetivas será relatada uma situação vivida em um núcleo familiar cuja mãe vivia com suas filhas gêmeas, que chamaremos de Júlia e Judite. Júlia havia nascido com baixo peso e necessitando de cuidados especiais da mãe durante longo período e apresentava problemas de aprendizagem escolar, enquanto Judite se destacava academicamente. Essa 
situação causava comparações por parte da escola ainda que as duas estudassem em classes distintas. No núcleo familiar a mãe trabalhava e dividia com as meninas as tarefas domésticas. Certa vez, cansada com a falta de contribuição das filhas e com a desorganização da casa, a mãe falou de seus sentimentos em não desejar voltar à residência quando saía do trabalho, pois era consciente do que a aguardava: a desorganização da casa e as brigas constantes entre as filhas. Após esse dia, sempre que a mãe saia para o trabalho Júlia chorava ou reclamava de alguma dor. Passado algum tempo e diversas tentativas da mãe em compreender a reação da fillha, Júlia expressou que sua insegurança advinha do pensamento de que a mãe sairia e não voltaria mais para casa, uma vez que a própria mãe havia introduzido esta hipótese. Ao ouvir o relato, Judite respondeu que isso jamais aconteceria, e sorriu ao perceber o sofrimento da irmã diante de uma fala materna que havia ocorrido em momento anterior.

A reação de Júlia não pode ser observada como uma situação isolada e decorrente unicamente da fala da mãe. O choro de Júlia após a manifestação oral da mãe sobre suas angústias naquele ambiente parece ter produzido sentidos subjetivos que podem ter constituído o abandono como configuração subjetiva. Não de forma linear, como reação de causa e efeito, mas como produção sistêmica da subjetividade, constituída a partir de outras situações vividas e subjetivadas por Júlia, como a necessidade maior de cuidados da mãe nos primeiros momentos de vida, a dificuldade de aprendizagem escolar, a proteção da mãe para evitar comparação entre elas. Não se podem descrever sentidos produzidos no comportamento de Júlia, simplesmente por esse relato, por isso o termo "parece", pois sentidos subjetivos não podem ser compreendidos de modo direto a partir de um comportamento. Esse exemplo procura demonstrar a singularidade da dimensão subjetiva, uma vez que as irmãs viviam no mesmo contexto histórico-cultural, financeiro e social. Porém a configuração subjetiva frente à fala materna configurou-se diferentemente para as duas irmãs, com sentidos subjetivos singulares. Conforme González Rey (2005a):

As configurações subjetivas envolvem uma forma única de produção de sentido
singular de cada sujeito concreto dentro de seus diferentes tipos de atividade. Isso
significa que não existem formas universais de subjetivação de uma atividade
concreta. Os diferentes tipos de atividades incluirão sentidos subjetivos distintos, que
provêm da história do sujeito e da diversidade dos contextos atuais de sua vida. Esses
dois momentos são inseparáveis na produção de sentido, sem que essa
inseparabilidade suponha formas lineares de dependência e, tampouco,
encadeamentos regulares e padronizados (p. 36).

O conceito de sujeito se refere ao indivíduo ativo, reflexivo, intencional, atual e interativo, que se relaciona com o Outro nos diversos contextos sociais. Essa categoria envolve 
pensamento, percepção, ação, sentimentos, linguagem e emoção, "a emoção é uma condição permanente na definição do sujeito. A linguagem e o pensamento se expressam a partir do estado emocional de quem fala e de quem pensa" (GONZÁLEZ REY, 2004b, p. 236).

As situações de conflito e de tensão impulsionam a emergência do sujeito, de modo recíproco, pois ele tanto emerge dessas situações quanto se fortalece nelas. Nesses momentos de conflito, tensão e criação é que o sujeito expressa na ação, configurações subjetivas constituídas ao longo de sua história, de modo consciente, tomando decisões e assumindo responsabilidade por elas (MITJÁNS MARTÍNEZ, 2004; GONZÁLEZ REY, 2005a). De acordo com González Rey (2004a) :

O sujeito existe sempre na tensão da ruptura ou da criação, momentos que se caracterizam por uma processualidade que desafia o instituído, tanto no nível da própria subjetividade individual, como em termos do social. O posicionamento ativo do sujeito permite-lhe o posicionamento crítico diante do estabelecido, o que representa um aspecto importante para a democracia e para o desenvolvimento, tanto individual quanto social ( p. 22).

A partir da emergência do sujeito que faz parte de um grupo, podem surgir reflexões e desenvolvimento desse grupo social em que o sujeito está inserido. Como em situação vivida por um dos colaboradores desta investigação, quando estava matriculado em escola que oferece Atendimento Educacional Especializado - AEE no modelo oralista. Esse estudante reivindicou o direito de escolha da língua adotada no espaço educacional. Para isso, liderou um instrumento de abaixo-assinado, intitulado: "Direito pode LIBRAS ou falar! Direito", reivindicando o direito da utilização da Língua de sua preferência, desejoso de ser respeitado nesta escolha, conforme os trechos de sua produção escrita salientam:

"Você acha que surdo entender o que professor está falando? Não é nada entender! Eu quero livre LIBRAS, meu direito pode LIBRAS ou falar. Não precisa obrigação falar, alguns surdos não gosta fono. Que absurdo!! Não pode LIBRAS que absurdo!!! (...) Você acha que surdos é burro? Nunca!!! Quero LIBRAS!!!” (BERTHIER ${ }^{5}$, 2013).

Além de refletir e questionar sobre o uso exclusivo da língua oral naquele espaço, o estudante convidou à reflexão, os dirigentes da escola, quando argumentou: "Você acha que os surdos estão entendendo o que os professores falam?" Ao que ele mesmo respondeu: "não estamos entendendo nada". Berthier provocou ainda os estudantes à reflexão, sem

\footnotetext{
${ }^{5} \mathrm{O}$ nome fictício, é uma homenagem a Ferdinand Berthier, líder surdo que viveu nos anos de 1880 e contribuiu significativamente com o movimento organizado de luta contra o oralismo (STROBEL, 2009).
} 
obrigatoriedade de que eles participassem da reivindicação. Portanto, Berthier assume completa responsabilidade pelo instrumento, conforme outro trecho do abaixo assinado: "Você quer que professores usem LIBRAS ou falar? Se você quer? Vamos colocar seu nome aqui! Se você não quer que professores, não colocar seu nome aqui não Ok?" (BERTHIER, 2013).

No caso acima, podemos compreender que vários estudantes vivenciavam a situação de obrigatoriedade do uso da língua oral para se comunicar nessa escola. Porém a provocação de Berthier que considerou a possibilidade de, por meio desse instrumento, modificar uma realidade, provocou a reflexão nos outros sobre o enfrentamento da questão linguística no contexto da escola. Após conhecer o documento de abaixo-assinado utilizado por Berthier, a pesquisadora visitou sua página do Facebook na data do abaixo-assinado e pode perceber a discussão que ocorreu naquela rede social. De modo singular, foram feitos vários posicionamentos, dentre eles o de estudantes ou ex-estudantes surdos dessa mesma escola que se posicionavam favoráveis ao uso único da oralização e manifestavam como se sentiam gratos por serem oralizados no momento atual. Em oposição, havia o grupo dos estudantes que defendia o uso exclusivo da Libras na escola e falava dos traumas causados pela obrigatoriedade da oralização. Havia ainda, o grupo do qual Berthier participava e que defendia a proposta do uso das duas línguas nesse espaço educacional, conforme a escolha de cada estudante.

O que caracteriza a emergência do sujeito é a reflexão, a ação consciente, o ato de assumir a responsabilidade por suas escolhas. Mas há situações em que a emergência do sujeito pode ser revelada numa aparente subordinação, desde que a subordinação seja uma decisão consciente do indivíduo e que contenha as características citadas acima (GONZÁLEZ REY, 2013).

Assim como a subjetividade, a categoria sujeito pode ser percebida tanto no nível individual, quanto no nível social, em grupo que "legitima seu valor, que é capaz de gerar ações singulares e que mantém sua identidade através dos vários espaços de contradições que necessariamente caracterizam a vida social" (GONZÁLEZ REY, 2012b, p. 153).

A Teoria da Subjetividade na perspectiva histórico-cultural de González Rey, rompe com a dicotomia individual-social, já que o indivíduo também se constitui da subjetividade social dos espaços em que vive. Por sua vez, a subjetividade social desses espaços se constitui da subjetividade dos indivíduos que dela participam. De modo recíproco, subjetividade individual e social constituem-se mutuamente. No entanto, a subjetividade social não é a soma das várias subjetividades que fazem parte desse coletivo. Mas, subjetividade social é um sistema complexo com: "dois espaços de constituição permanente e inter-relacionada: o individual e o 
social, que se constituem de forma recíproca e, ao mesmo tempo, cada um está constituído pelo outro" (GONZÁLEZ REY, 2012b, p. 141).

É importante salientar, que a subjetividade social é um sistema integral de configurações subjetivas de espaços concretos da sociedade. E não pode ser confundida com reflexos de nenhum de seus sistemas constituintes, pois se trata de uma produção que se nutre de todos os sistemas, processos e fatos que são parte daquela sociedade. Além disso, não pode ser associada a situações vividas no momento presente por um grupo social, mas no modo como a situação vivida no presente adquire significação e sentido a partir da história daquele grupo social (GONZÁLEZ REY, 2005a).

O estudo de Orsoni (2007), investiga a subjetividade social de uma escola em que se estabeleceu um espaço de compartilhamento entre uma professora Surda e os familiares dos alunos. Segundo Orsoni (2007), as produções emergentes nesse espaço dialógico, possibilitaram a postura reflexiva de Emília, mãe de uma criança surda matriculada naquela escola e que considerava as pessoas surdas como incapazes intelectualmente. Segundo relato da própria mãe, ao se deparar com uma Surda, professora e independente, começou a refletir sobre as potencialidades de seu filho e a percebê-las no cotidiano. Conforme relato de Emília, colaboradora da pesquisa de Orsoni (2007):

A professora era uma mulher arrumada, bem vestida e sabia ler e escrever. Aí eu pensei: ele tem uma chance e não vai ser bobo não; e comecei a trabalhar em cima disso, vim me ligar que existia a língua de sinais, que também não sabia, nunca tinha visto. Eu sabia daquele alfabeto manual, mas Libras eu não conhecia não (ORSONI, 2007, p. 95)

As configurações subjetivas de Emília constituídas historicamente, diante das experiências significativas vividas no espaço escolar, foram reconfigurando seu olhar para o Surdo e as possibilidades de seu filho. Deste modo, a escola como espaço social subjetivado pode contribuir para o desenvolvimento das pessoas que daquele espaço participavam. A professora surda e os pais que compunham aquele grupo social foram compartilhando seus processos e tensões o que permitiu a reflexão e a produção de novos sentidos subjetivos e desenvolvimento da mãe citada. A reconfiguração subjetiva da mãe se converteu em ações e reverberaram em sua constituição subjetiva individual, assim como na subjetividade social da escola e daquela família.

Importa considerar o caráter indivisível da subjetividade individual e da subjetividade social: 
[...] excluir a dimensão individual da subjetividade social leva a ignorar a história do social em sua expressão diferenciada atual que se expressa nos indivíduos. Negar o indivíduo como singularidade subjetivamente constituída é ignorar a complexidade da subjetividade, a qual se constitui simultaneamente em sua multiplicidade de níveis, que podem ser contraditórios entre si, mas de cujo funcionamento depende dos diferentes momentos do desenvolvimento subjetivo (GONZÁLEZ REY, 2012b, p. 37).

A subjetividade individual não se constitui de uma influência externa interiorizada pelo indivíduo, mas como um processo sistêmico, complexo e organizado de configurações subjetivas da ação do sujeito individual, em constante desenvolvimento e expressadas na ação do sujeito individual.

A subjetividade individual de uma criança está constituída por suas histórias subjetivadas, e simultaneamente por configurações subjetivas dos diversos grupos sociais em que essa criança participa. Assim, entende-se que uma criança surda se constitui da subjetividade social de sua família, de sua escola e dos demais grupos sociais que estabelece relações.

Após discutir as categorias da Teoria da Subjetividade na perspectiva histórico-cultural de González Rey, consideram-se as implicações significativas que motivaram a pesquisadora a optar por esse modelo teórico. Pode-se refletir que o referencial teórico adotado nessa produção pode contribuir para dar inteligibilidade à compreensão da pessoa surda em suas dimensões histórico, cultural, sistêmica, social, integral e que produz sentidos subjetivos a partir das experiências vividas. Todas as dimensões acima citadas se configuram constituindo a pessoa surda complexa e singular. Portanto, o referencial teórico adotado, rompe com o modelo hegemônico que divide surdos e deficientes auditivos a partir do modo como se comunicam, se são oralizados ou sinalizadores. 


\section{PROCESSOS COMUNICATIVOS}

O termo comunicação remete à troca interacional de mensagem e à ligação entre pessoas. Marques de Melo (1975), partindo da etimologia do termo, afirma que comunicação vem do latim communis, ou seja, tornar comum. Também remete à ideia de comunhão, comunidade. No que diz respeito ao termo processo, o dicionário Aurélio (FERREIRA, 2009) afirma que vem do latim processu "ato de proceder, de ir por diante, seguimento, curso, marcha. Sucessão de estados ou de mudança” (FERREIRA, 2009, p.1.634). Portanto, nessa perspectiva do senso comum, na compreensão literal da expressão, os processos de comunicação são a simples troca de mensagens comuns entre pessoas.

Desde o nascimento, o ser humano procura comunicar-se. O choro é a primeira comunicação do bebê com seus cuidadores e pode revelar o estado de fome, de sono, de dor ou qualquer outra necessidade. Os primeiros cuidadores passam a identificar, conforme o choro do bebê, o que este expressa a cada momento.

Para além do choro, o bebê estabelece contato visual e outras formas de comunicação, que vão se ampliando conforme vai crescendo, como por exemplo, a apontação. Passa a interagir com as pessoas mais próximas e estabelecer com elas uma relação. À medida que interage, vai se desenvolvendo nas trocas e nas relações que estabelece.

Para Tacca (2006), os modos de comunicação são ampliados à medida que se desenvolvem, conforme o padrão do seu grupo social, no qual a criança está inserida, sendo a comunicação uma necessidade cultural humana. Através da comunicação pode ser transmitida a cultura, ou seja, o conjunto de valores, crenças, mitos e normas de um grupo social, essa transmissão pode ocorrer nas produções escritas e nas relações interativas que se estabelecem por meio de códigos, línguas ou sistemas de comunicação.

Já a língua, segundo Saussure (1969) é um sistema articulado de signos, com normas e variações linguísticas que são organizados coletivamente. Os sistemas de comunicação, referem-se ao modelo que possui uma fonte, um transmissor, um canal, um receptor e um destino. Nessa investigação, a opção pelo termo processos comunicativos se refere à interação entre os interlocutores, que podem utilizar diferentes formas e códigos, signos, símbolos, ou uma língua comum para se comunicarem. Além dos estudiosos da comunicação de dados, linguistas e psicólogos ocuparam-se desse tema. 


\subsection{Comunicação na perspectiva da linguística}

Ao considerar que uma das funções da linguagem é a comunicação, estudiosos da linguagem buscaram os conceitos da teoria da informação e da comunicação para desenvolver o estudo da comunicação no campo da linguística. A teoria da informação e da comunicação, sobretudo nos anos de 1950, exerceu grande influência nos estudos da Linguística.

Um autor que explica a teoria da informação é Shannon (1948) que organizou um modelo da comunicação como a transferência de mensagens entre um transmissor e um receptor com o uso de um código em uma sequência de sinais (BARROS, 2001).

Barros (2001) afiança que o linguista Jakobson (1969), partindo do modelo de Shannon (1948), desenvolveu estudos para adequar a teoria da informação/comunicação ao que propõe a linguística. Jakobson (1969) postula que na troca comunicacional devem ser consideradas as variedades das funções da linguagem. A teoria da informação desenvolveu estudos ocupandose da linguagem informativa, mas a linguística necessitou reconhecer as diversas finalidades da comunicação humana, como as funções poética, fática, metalinguística, expressiva, apelativa, representativa (BARROS, 2001).

Apesar de validar as contribuições de Jakobson, Barros (2001) adverte para a abordagem mecanicista que prevalece nos seus pressupostos, pois “[...] não examina adequadamente as relações ideológicas da comunicação, e praticamente não tratava da reciprocidade característica da comunicação humana" (p. 41). É importante avançar a partir do que Jakobson (1969) propõe, no estudo dos processos comunicativos humanos, investigando também os espaços relacionais estabelecidos entre os interlocutores e a intencionalidade expressa na comunicação de cada um deles.

A comunicação embasada nos modelos da teoria da informação segue a lógica da linearidade, considerando apenas a transmissão da mensagem entre um emissor e um receptor desconsiderando a reciprocidade, a possibilidade de transformação do receptor em emissor e o caráter complexo da comunicação humana.

Os linguistas, ao ampliarem os conceitos da teoria da informação, dividiram o estudo em áreas. Deste modo, ficaria a cargo dos estudos da sintaxe os problemas de código, canais, capacidade, ruído e outras propriedades da linguagem. A semântica que se ocuparia com o significado da mensagem. Já a pragmática estudaria a mudança de comportamento a partir da recepção de uma mensagem (WATZLAWICK, BEAVIN \& JACKSON, 1973).

Por exemplo, nesse processo, os fatores que podem interferir na comunicação são como ruídos. Numa percepção ampliada, a teoria da informação explica que, os ruídos podem ser de 
ordem cultural, quando palavras ou frases são complicadas ou ambíguas, ou quando a língua utilizada não é comum entre os interlocutores, situação comum aos surdos. Podem ocorrer ainda, ruídos de ordem psicológica, quando há agressividade ou antipatia na relação. Uma das causas de ruído na comunicação é o uso de um código não conhecido por um dos interlocutores ou o fato de um dos interlocutores não estar envolvido psicologicamente, ou um dos interlocutores não possuir capacidades fisiológicas que permitam acessar a mensagem como é o caso dos Surdos, colaboradores dessa investigação que não têm acesso às propriedades sonoras da língua (BLIKSTEIN, 2016).

Isso é evidência de que a comunicação foi também investigada por outras ciências como a psicologia, sendo a comunicação uma das categorias da psicologia soviética (GONZÁLEZ REY, 2013).

\subsection{Comunicação na perspectiva da psicologia}

Na esteira do pensamento de González Rey (1995, 2004b), essa investigação busca avançar para uma compreensão da comunicação com caráter processual, sistêmico e complexo como veremos adiante. Há que se considerar os aspectos histórico-culturais envolvidos no processo de comunicação das pessoas. Do mesmo modo, a ação de comunicar-se não pode ser vista como um produto, mas se configura na ação do processo comunicativo, donde participam sentidos subjetivos produzidos nos mais diferentes espaços e vivências dos interlocutores. Nessa perspectiva, o processo interacional e a dimensão discursiva são fatores muito relevantes para compreensão da mensagem, pois o significado é construído para além do valor referencial dos signos e depende do contex to e da relação que os interlocutores estabelecem.

Segundo González Rey (2012a), na psicologia histórico-cultural, diversos autores deram centralidade aos estudos da categoria comunicação. B. G. Ananiev (1907-1972) fundamentou seus estudos da personalidade nas categorias de comunicação e da atividade e buscou compreender os problemas da relação professor-aluno. A partir dessas investigações, estendeu suas hipóteses a outros fenômenos de relação humana. $\mathrm{O}$ autor critica o conjunto da obra de Vigotsky, em que, segundo ele, enfatiza a linguagem em detrimento da comunicação que é mais abrangente, mesmo que Vigotsky $(1997,2007)$ postule que nas situações de coletividade entre as crianças ocorre o diálogo autêntico e desenvolvedor e nessas situações comunicativas se estruturam e se desenvolvem as funções psicológicas superiores como a memória, atenção voluntária, pensamento de conceitos. Segundo González Rey (2012), para Ananiev, é no processo de comunicação que se desenvolvem os acordos, a simpatia, a 
cooperação, os conflitos e contradições que estão para além do intercâmbio de ideias e possibilitam uma compreensão e desenvolvimento dos interlocutores (GONZÁLEZ REY, 2012a, 2016).

[...] a linguagem representa o meio essencial da comunicação, mediante o qual se realiza o processo de assimilação dos conhecimentos historicamente mais complexos pela criança, isto é, o processo de estabelecimento de seu pensamento lógico e de outras formas mediadas de sua atividade cognitiva. Mas esses processos não ocorrem somente na linguagem, como frequentemente tem sido fetichizada a linguagem como fator do desenvolvimento psicológico, mas sim na síntese da comunicação e do conhecimento que constitui a base da linguagem e da fala. (ANANIEV 1997, p. 164165, apud GONZÁLEZ REY, 2012a, p. 150).

Ainda segundo González Rey (2012a), em continuidade às ideias de Ananiev, seu aluno Lomov (1979) questiona as produções de A. A. Leontiev onde a comunicação possui relação direta com a categoria de atividade objetal, em que “[...] o objeto substitui o caráter relacional, simbólico e discursivo dos processos sociais" (GONZÁLEZ REY, 2012a, p. 246). O rompimento de Lomov com o modelo proposto pela teoria da atividade de A. A. Leontiev permite a abertura da categoria comunicação como princípio para o desenvolvimento de diferentes campos da psicologia, seja na psicologia social, na institucional e na psicoterapia, uma vez que ressalta a relação entre comunicação e aspectos da psique. A partir da década de 1970, o tema da comunicação como princípio abriu a discussão para temas como a personalidade e a subjetividade (GONZÁLEZ REY, 2012a , 2016).

Já Bozhovich (1908-1981), pesquisou o desenvolvimento da comunicação em crianças e ressaltou a necessidade desta comunicar-se com o adulto, não apenas para satisfazer suas necessidades básicas como alimentação, banho e outros, mas porque essa comunicação permite acessar a cultura, gerando outras necessidades no processo de desenvolvimento singular da criança (MITJÁNS MARTINÉZ, 2016).

Freire (1983) afirma que o homem, como ser pensante e social, nutre-se do pensamento do outro para significar e compreender objetos e/ou acontecimentos. Para nutrir esse pensamento utiliza-se da comunicação entre ele e seus interlocutores. O autor rompe com a lógica do pensamento como interno e individual e manifesta que todo pensamento é mediatizado pela comunicação com o outro e surge da coparticipação com o outro, ou outros. Postula ainda que a comunicação só é legítima a partir de um diálogo/comunicativo.

Acredita-se que essas considerações sejam suficientes para dizer que é através do diálogo/comunicativo que os interlocutores se convertem em sujeitos comunicativos e, deste modo se apropriam da cultura e se envolvem no processo de desenvolvimento de suas 
singularidades subjetivas. Assim considerando o postulado de Freire (1983) e de González Rey (1995, 2004b), para que haja comunicação dialógica é necessária a emergência do "sujeito comunicador", ou seja, pessoa ativa, reflexiva e que utiliza os signos linguísticos para defender suas posições ou para calar-se diante de colocações de outrem de modo intencional. Quando esse processo de conversão do interlocutor em "sujeito comunicador" não ocorre, Freire (1983) considera que não houve comunicação efetiva, pois para que ela aconteça não pode haver passividade.

\subsection{Processos comunicativos de Surdos}

As primeiras interações do bebê ocorrem com sua família. Porém, no caso das crianças surdas, em que 95 \% são filhas de pais ouvintes (GOLDFELD, 2002), elas deixam de ter garantia de acesso à língua oral de seu país e tampouco da língua de sinais de forma natural, ou seja, apenas no contato com outros falantes.

Inicialmente, as crianças surdas comunicam-se com os familiares, assim como as outras crianças, desde o choro, a troca de olhar e o balbucio. As pesquisas de Petitto e Marantette (1991) comprovaram que inicialmente os bebês ouvintes e surdos balbuciam de forma oral e em gestos. As crianças surdas, à medida que vão crescendo e não recebem o estímulo auditivo cessam o balbucio oral e desenvolvem o balbucio gestual, já com as crianças ouvintes ocorre o contrário, à medida que recebem estímulos auditivos deixam de balbuciar em sinais e passam a balbuciar oralmente e posteriormente emitir palavras.

Colin (1980) postula que, à medida que as crianças surdas vão crescendo, os pais esperam o retorno de sua troca comunicativa, ou mesmo uma palavra sussurrada. O autor advoga que essa espera gera ansiedade e pode causar frustração nos pais.

A criança surda pode sentir-se insegura e compreender-se como incapaz de estabelecer diálogos, uma vez que a síntese da comunicação para a qual essa é orientada ao longo de seus primeiros meses de vida com o conhecimento que vai se constituindo na base da linguagem e da fala para a qual a criança surda não avança porque lhe faltam parceiros comunicativos que sustentem o processo de desenvolvimento da linguagem.

A ausência de um código comum impede ou altera as interações comunicativas e assim, não apenas os processos linguísticos, como por exemplo, as escolhas entre os códigos orais ou gesto-visuais, mas os processos comunicativos que passam a ser precários e até inexistentes.

Assim, de qualquer forma, tanto pelo enfoque linguístico, quanto pelo enfoque psicológico, deve-se reconhecer que usos da linguagem e processos de comunicação tornam-se 
um desafio no desenvolvimento de pessoas surdas. Nossa questão é se vamos optar por um enfoque que reduza a compreensão desses desafios a processos linguísticos ou se vamos procurar compreendê-los em função das formas singulares de como as pessoas surdas se organizam, ou não, para enfrentá-los.

A seguir serão apresentadas características gerais dos sistemas com os quais a comunidade surda vem se debatendo desde o início do uso de sinais na escola e mais fortemente desde o Congresso de Milão, quando houve a proibição do uso das línguas de sinais nos espaços institucionalizados.

Para melhor compreensão dos sistemas comunicativos adotados por Surdos, serão apresentadas as seguintes categorias: sistemas comunicativos embasados no oralismo, na sinalização ou nos processos híbridos de comunicação.

\subsubsection{Sistemas oralistas}

Conforme Santana (2007), alguns surdos rejeitam a língua de sinais motivados pelo fato de sua família considerar, no seu uso, a identificação com a surdez e, portanto, com o universo da deficiência, pois a surdez, por si só, não possui essa marca, mas na comunicação em língua de sinais é manifestada a condição de surdo. Portanto, comunicar-se em língua de sinais - por ser uma língua gesto-visual - atrai olhares, legitimando o desenvolvimento atípico do seu falante.

Para os defensores da perspectiva oralista, a língua oral é a única forma desejável para a comunicação dos surdos (GOLDFELD, 2002). Nessa perspectiva, várias estratégias são adotadas tanto para emissão como para a recepção da mensagem no processo de comunicação, valorizando sempre a fala oral, a leitura labial ou o resíduo auditivo. Para isso, treino de fala e o aproveitamento do resíduo auditivo por meio de sua amplificação são aspectos importantes no processo de oralização das crianças surdas, adotados nas escolas e clínicas sob essa perspectiva.

Dentre os métodos adotados para o ensino da fala pode-se citar o método maternoreflexivo. Trata-se de método oral puro destinado, primordialmente, a surdos profundos prélinguísticos ${ }^{6}$ e assenta no papel determinante da conversação, pois segundo Van Uden (1997) o surdo precisa de alguém com quem conversar, algo que conversar e um desejo de conversar" (AFONSO, 2007, p. 18).

\footnotetext{
${ }^{6}$ Considera-se surdez pré-linguística, aquela adquirida antes da aquisição de linguagem.
} 
Outro método utilizado é o método verbo-tonal, que estimula todos os canais auditivos, visuais, gestos sensoriais para que se adquira a linguagem oral. O canal auditivo é estimulado pela amplificação do resíduo auditivo da criança surda. Criado por Guberina, utiliza instrumentos desenvolvidos especialmente para o método, Sistema Universal Verbo-tonal de Audição Guberina, SUVAG.

Dentro dos sistemas de comunicação oral, um recurso muito usado recentemente é o implante coclear, cuja centralidade é a audição que é possibilitada a partir de implante de dispositivo eletrônico que transforma "energia sonoras em impulsos eletroquímicos" (KELMAN, 2011, p. 177), sendo, portanto, a implantação de eletrodos na cóclea. Segundo Kelman (2011), em 1990, ocorreu o primeiro implante coclear no Brasil. Mais recentemente com a obrigatoriedade da Triagem Auditiva Neonatal, popularmente conhecido como "teste da orelhinha", o diagnóstico da surdez ocorre mais precocemente, assim como os implantes cocleares, são cada vez realizados mais cedo. Em Brasília, há registros de crianças implantadas aos seis meses de idade.

Segundo Kelman (2011), os pais que submetem os filhos à intervenção cirúrgica de implante coclear desejam que os filhos falem. Nesses casos, a família cria a possibilidade da “normalização da surdez" através da escuta e oralização, por isso aposta no implante coclear. Porém, na realidade, nem sempre isso acontece. Essa constatação é corroborada pelo estudo de Buzar (2015), que investigou Emmanuelle, jovem surda, que aos 10 anos foi submetida a cirurgia de implante coclear sem ser consultada ou comunicada anteriormente. Em seguida, a família afastou-a dos amigos sinalizadores. Emmanuelle não desenvolveu habilidades de ouvir e falar após a intervenção cirúrgica. Essas situações vividas levaram a jovem a situação de sofrimento psíquico.

Resta esclarecer que a opção por colocar o implante coclear no campo dos sistemas oralistas foi embasada no discurso de algumas propostas oralistas, decorrentes do implante coclear e vigentes em Brasília, que sugerem o afastamento do convívio com surdos falantes de Língua de sinais para evitar a aprendizagem dessa, sob alegação do alto custo da intervenção cirúrgica e que poderia ser um investimento financeiro perdido caso haja o contato com a Língua de sinais. Mais do que um sistema de comunicação, no entanto, o implante coclear pode ser considerado um equipamento. 


\subsubsection{Sistemas sinalizadores}

Mesmo nas famílias que não apoiam o uso da língua de sinais, podem ser criados sinais caseiros como recurso comunicativo por aquele grupo familiar e, à medida que são usados, vão sendo convencionados, naquele grupo de interlocutores. Vilhalva (2012) nomeia esse processo de criação como sinais emergentes, uma vez que:

[...]foram criados devido a uma necessidade de comunicação, passando por sinais indicativos e icônicos arbitrários. As maneiras como cada sinal surge leva tempo para se entender, principalmente quando os sinais são criados conforme o neologismo. Esses novos sinais passam a fazer parte da comunicação para depois designar algo consistentemente (p. 137).

Laborrit (1994) fala de sua percepção sobre os sinais caseiros que desenvolveu com a mãe. Nesse caso, tratava-se de comunicação na qual o pai não participava:

Nossa maneira de nos comunicarmos era instintiva, animal, chamo-a de 'umbilical'. Tratava-se de coisas simples, como comer, beber, dormir. Minha mãe não me impedia de gesticular, como lhe haviam recomendado. Não tinha coragem de me proibir. Tínhamos signos nossos completamente inventados (LABORIT, 1994, p. 17).

Quando a comunicação estabelecida se restringe aos sinais caseiros, as crianças surdas têm acesso parcial à cultura porque as regras sociais são feitas para elas e não com elas, transformando o Surdo em "paciente de seus comunicados" (FREIRE, 1983, p. 45). Mas para um indivíduo assumir como seus os valores, crenças e mitos de um grupo social é necessário um processo que envolve o questionar, interrogar e até negar esses valores e regras sociais, para só então assumi-los como seus em uma construção própria, real e autêntica. (GONZÁLEZ REY, 1995).

Tal reflexão é ratificada pela pesquisa de Lebedeff e Rosa (2013), que mostra uma situação de riqueza de sinais caseiros desenvolvida por uma família com dois irmãos surdos. Os sinais caseiros utilizados pelos irmãos da cidade de Jacaré dos Homens, em Alagoas, eram compartilhados por toda a família e comunidade local. Além dos irmãos surdos, os três irmãos ouvintes e os pais continuaram a utilizar os sinais caseiros em encontros familiares mesmo após a aquisição de Língua de sinais pelos irmãos. A situação chama atenção, uma vez que, haviam dois irmãos surdos no grupo familiar, o que permitia a troca entre pares. Além do interesse de outros familiares e comunidade em utilizar esse sistema comunicativo, situação pouco comum. Mesmo nessa situação com uma riqueza de sinais criados, mais de 60, e de um grupo maior de interlocutores, Lebedeff e Rosa (2013) relatam o estranhamento que o contato com a Libras 
causou aos dois irmãos pelo quantitativo de vocabulário e conceitos que a Libras permitia acessar.

A vivência dos irmãos de Jacaré dos Homens é distante da realidade de grande parte dos surdos, que vivem em situação de isolamento geográfico. Comumente encontra-se um único surdo em um bairro, ou em uma sala de aula ou escola. Assim, as trocas comunicativas ocorrem apenas no âmbito da família e posteriormente na escola com o professor ouvinte que nem sempre possui proficiência em Libras.

Outro meio de comunicação utilizado por surdos que não conhecem a língua de sinais ou quando o interlocutor não a conhece é a apontação. Goldin- Meadow (2003) compreende a apontação como conjunto de gestos dêiticos, utilizados para direcionar o olhar do interlocutor para onde se encontra o objeto, pessoa ou lugar. As crianças surdas costumam combinar a apontação com outros gestos para comunicar-se, como os sinais caseiros ou mímicas. No que diz respeito à mímica seria a imitação e a expressão dos pensamentos através de gestos. (ZILIO, 2012).

Até às pesquisas de Stokoe (1960), as línguas de sinais eram consideradas como mímica, Stokoe foi o primeiro a apresentar resultados de pesquisa que comprovaram que as línguas de sinais possuem as mesmas características das línguas orais, o que as legitima como língua natural dos surdos. Considera-se como língua natural aquelas que são adquiridas pela criança através da interação com outros falantes (QUADROS \& KARNOPP, 2004). O canal gestovisual utilizado difere das línguas oral-auditivas, conforme comprovam as pesquisas de Fernandes, (2005), Guarinello (2007), Quadros e Karnopp (2004).

As línguas de sinais permitem expressar conceitos abstratos, emoções e sentimentos. Além disso, os sinais possuem significado, sistemas arbitrários e regras gramaticais independentes das regras das línguas orais com as quais convivem. (QUADROS \& KARNOPP, 2004). Inclusive, não se trata de uma única língua universal, pois cada país possui sua língua gestual própria.

As línguas de sinais podem ser escritas através de vários sistemas, como a Escrita de Língua de Sinais - ELAN (ESTELITA, 2007), mas o sistema mais conhecido é o Sign Writing. De acordo com Stumpf (2004) esse sistema de escrita de sinais foi criado na Califórnia por Valerie Sutton por volta de 1974:

Trata-se de um sistema para representar línguas de sinais de um modo gráfico esquemático que funciona como um sistema de escrita alfabético, em que as unidades gestuais fundamentais, suas propriedades e relações. A Sign Writing pode registrar qualquer língua de sinais do mundo sem passar pela tradução da língua falada. Cada 
língua de sinais vai adaptá-lo a sua própria ortografia. Para escrever em Sign Writing

é preciso saber uma língua de sinais (STUMPF, 2004, p. 147-148).

Até mesmo entre os surdos que falam as diversas línguas de sinais, houve a necessidade de criação de um código comum. Foi assim que surgiram os Sinais Internacionais - SI. Para Bauman e Murray (2014) os registros do uso inicial de Sinais Internacionais - SI, popularmente conhecido como Gestuno, foram os banquetes promovidos pelos surdos desde o século XIX. Nessas ocasiões, que reuniam líderes surdos de diferentes países e falantes de diferentes línguas de sinais, houve a necessidade de um código comum para que pudessem se comunicar. Atualmente, os SI são muito utilizados em Congressos Internacionais e eventos esportivos, que reúnem os surdos, também informalmente nas viagens internacionais que eles fazem ou quando se comunicam virtualmente com surdos de outros países. Há uma carência nas produções científicas sobre os Sinais Internacionais, algumas investigações sobre esse tema ainda estão em desenvolvimento. Os homens criam estratégias para se comunicar e romper de forma criativa com as barreiras de comunicação. Nesse sentido, houve a criação do Gestuno, que pode ser considerada como emergência do sujeito social, uma vez que surgiu da necessidade comunicativa de grupos de Surdos, o que permite a escolha de interlocutores, rompendo com os limites geográficos.

O Gestuno possibilita trocas comunicativas e conhecimento de outras culturas, com independência da figura do intérprete. Como exemplo cita-se o caso de grupos de jovens surdos de três nacionalidades distintas que se conheceram em Congresso Internacional de Líderes Surdos, que ocorreu em 2007, na Dinamarca. Após o referido congresso, trocaram vídeos mensagens e já foram hospedados um na casa do outro em seus respectivos países. Em depoimento, um dos participantes do congresso falou orgulhoso de sua independência e de seu desejo de conhecer outros países e, como líder, propiciar e incentivar crianças e jovens surdos a viverem situações semelhantes (MACHADO, 2015 depoimento pessoal).

\subsubsection{Sistemas híbridos}

Estamos chamando de sistemas híbridos aqueles que se valem da sinalização e da língua oral simultaneamente. É o caso do português sinalizado, que pode ser considerado tanto um momento do processo de aquisição da língua de sinais e/ou como uma forma de legitimar o poder das línguas orais sobre as línguas de sinais. Existem grupos de ouvintes e de surdos que mesmo conhecendo um vocabulário amplo em língua de sinais optam por utilizar, na comunicação, o padrão estabelecido pela língua oral. 
Outro sistema híbrido é a comunicação multimodal que permite que o professor se apoie "em múltiplos modos semióticos para que a criança surda possa construir significados" (KELMAN, 2011, p. 196). Portanto, são negociados pelos interlocutores o uso de signos textuais, de movimentos, de imagens e Língua de sinais. Como em situação presenciada nesta investigação em que o professor apresentou um exercício de questões de vestibular. Os alunos sabiam o conteúdo avaliado, porém responderam incorretamente uma questão que iniciava com o termo: Exceto. O professor escreveu a palavra no quadro e perguntou se a conheciam, eles afirmaram que não. Em seguida, escreveu no quadro: Vamos todos lanchar, exceto João. (Era quase horário do lanche). O professor se levantou e convidou os alunos para lhe acompanharem ao lanche, quando todos levantaram, apontou no quadro a palavra exceto e empurrou João para voltar a sua cadeira. Em libras, desenhando e escrevendo foi dando outros exemplos. Desenhou algumas frutas e falou que havia comprado frutas exceto bananas.

Nesse exemplo, o professor brinca e apresenta um novo vocábulo correspondente a um novo conceito aos alunos. Alguns copiam em seu dicionário, sinalizando: [EU NÃO CONHECIA PALAVRA E-X-C-E-T-O]. Em seguida o professor retoma a atividade escrita. O professor usou de estratégia para chamar atenção dos estudantes, observando as suas características. João, o aluno usado no exemplo, sempre repete o lanche da escola. Quando o professor chamou para lanchar, foi o primeiro a levantar.

\subsubsection{Processos comunicativos e o uso das tecnologias}

O incremento das Tecnologias de Informação e Comunicação - Tics potencializaram os processos de comunicação dos Surdos. A possibilidade de compartilhar informações registradas com o uso de diversos sistemas semióticos e consequentemente permitindo a informalidade nos usos da linguagem escrita, possibilitou o diálogo, a aproximação entre surdos e acesso aos textos. Observa-se a troca de vídeos informativos culturais e textos humorísticos entre surdos de diversos países. O uso das tecnologias legitima um espaço de construção, de enfrentamento e de desenvolvimento. Rompe com o isolamento geográfico vivido por muitos Surdos que não possuem contato com outro Surdo porque moram distante ou estudam em escolas diferentes (BITTENCOURT, FRANÇOZO, et al., 2011).

Com a tecnologia, os surdos dispõem de uma gama de possibilidades para a comunicação, pois o texto pode utilizar-se de ícones, de símbolos, de desenhos, de fotos, de palavras, textos, imagens de emoticons para além do uso da língua escrita que é uma dificuldade para os surdos. Desse modo, passa-se a contar com uma série de recursos que tornam possível 
a comunicação. Isso possibilita a inclusão da pessoa surda em práticas sociais que estão disponíveis para qualquer pessoa, ficando assim, a marca da surdez diluída nas formas de comunicação utilizadas na contemporaneidade. Schallenberger (2012) adverte sobre esse uso das tecnologias: "A internet é o meio virtual que se torna meio de conhecimento da comunidade e da língua surda. Que engraçado! Hoje em dia buscamos segurança no lugar mais inseguro possível” (p. 81).

Mas as tecnologia não se resume ao uso do computador, pois utiliza-se de diversas estratégias como os dispositivos luminosos que servem como campainha, o fax, o celular, relógios vibratórios que servem como despertadores, aparelho de telefone específico para surdos, close caption, que consiste no sistema de legenda oculta que descreve os sons presentes nas cenas em programas televisivos. Os recursos e programas tornaram-se mais acessíveis aos Surdos e podem ser utilizados no próprio aparelho celular, dando acesso às redes sociais com possibilidades de encaminhamento dos textos contínuos e descontínuos que podem ocorrer por meio de vídeos em Libras e o emprego de outros recursos, como imagens e fotografias.

De acordo com Kirkpatrick (2011), o Facebook é o maior site de rede social da história da humanidade, atingindo setecentos milhões de usuários. Foi construído inicialmente na Harvad University, com objetivo de identificar e criar uma rede social entre os novos estudantes e os veteranos da referida universidade. Desde 2006 é aberto a todos que conseguem acessar a internet (ROSA, 2012).

O Facebook permite a criação de um perfil e a troca comunicativa entre usuários. Os colaboradores desta pesquisa utilizam sistematicamente essa rede, tornando informações pessoais públicas aos participantes do site, que permitiu o seu uso como instrumento de pesquisa, como veremos mais adiante.

O Facebook, o Telegram, o WhatsApp e o Snapchat são ferramentas utilizadas para minimizar as situações de enfrentamento do uso do português uma vez que evitam o constrangimento da interação face a face que pode ocorrer entre falantes de línguas diferentes. Além disso, o tipo de escrita utilizado na internet não exige o rigor da escola, ademais, o uso do corretor ortográfico, no WhatsApp, pode ser um facilitador da escrita. O uso do corretor ortográfico no celular como facilitador é observado também nas situações de comunicação presencial, conforme relato de um dos colaboradores dessa investigação, que afirma usar o aparelho celular para escrever o que o outro não compreende através da fala ${ }^{7}$, conforme veremos adiante. O Snapchat envia vídeos que transmitem a mensagem, sem exigir uma

\footnotetext{
${ }^{7}$ Trata-se apenas de gesto-articulatório com a boca.
} 
explicação por escrito. Normalmente utilizam uma única palavra para designar uma imagem e isso é feito tanto por surdos como por não surdos, o que minimiza as diferenças entre os vídeos enviados por eles ou por qualquer colega não surdo.

Diante de tais colocações, é importante considerar que o uso das tecnologias pode minimizar a apartação da criança surda de sua coletividade (VIGOTSKY, 1997), pois permite o uso de jogos com suas regras e o diálogo entre surdos e não surdos.

É importante pontuar, o caso dos surdos isolados pesquisados por Sacks (1998), Martins (2010), Coelho e Cortes, (2013) que além de não possuírem uma comunicação efetiva apresentavam características típicas de inadequação social, falta de senso histórico e incompreensão de regras sociais devido ao grau de isolamento cultural, que remete ao postulado por Vigotsky (1997) sobre a importância do desenvolvimento da linguagem para a inserção social do indivíduo. Uma vez que os conceitos são formados a partir da experiência de significação da palavra. Um sistema simbólico compartilhado entre a criança e as pessoas de seu entorno possibilita o desenvolvimento dos processos conceituais de pensamento e o desenvolvimento dos processos conceituais retroalimenta o sistema simbólico compartilhado, pois, entre a criança e seu interlocutor estão acontecendo muito mais trocas do que as trocas linguísticas (MADEIRA-COELHO, 2011).

Ao conhecer sistemas comunicativos das pessoas surdas, importa discutir a comunicação como processo, conforme propõe a Teoria da Subjetividade na perspectiva histórico-cultural de González Rey.

\subsubsection{Comunicacão de surdos como processo complexo}

As primeiras produções de González Rey $(1985,1989$, 1995) traziam a comunicação como tema central para os estudos da personalidade humana. Naquele momento, o autor, embasado nas obras dos já citados autores, Ananiev e Lomov, reconhecia a comunicação como processo de desenvolvimento humano, por isso, rompe com o modelo instituído por A. A. Leontiev, onde a comunicação girava em torno do caráter objetal, em que "o objeto substitui o caráter relacional, simbólico e discursivo dos processos sociais" (GONZÁLEZ REY , 2012a, p. 246). A comunicação passava a ser compreendida como mais uma forma de atividade humana, minimizando sua importância (GONZÁLEZ REY, 2004b).

Para González Rey (1995), naquele momento histórico, a função principal da escola seria a comunicação, como base para o desenvolvimento do estudante que, à medida em que 
desenvolve sua capacidade de comunicar-se, desenvolve-se como pessoa e consequentemente ocorre a aprendizagem escolar tradicional:

Desde nuestro punto de vista, la fúncion predominante de dicha instituición es lá comunicación, y no la enseñanza, em su sentido literal, como historicamente se ha considerado. Por supuesto, muchos afirmarán que esa función és educativa, y és correto. (GONZÁLEZ REY, 1995, p. 1)

À medida que as produções de González Rey avançam, a comunicação começa a ser reconhecida como processo que participa da produção subjetiva. Nesse sentido, o autor discute a importância da comunicação autêntica, do diálogo no processo de desenvolvimento. Em 2004, ao referir-se ao diálogo, afirma:

Nós não entendemos o diálogo somente como um processo imediato e contextual que poderá ser reduzido as atuais trocas entre participantes. As pessoas nos diálogos geram sentidos subjetivos que estão relacionados não somente ao momento presente, mas a outras situações que também estão subjetivamente ligadas ao discurso presente. Esses sentidos são expressões de histórias pessoais. Estas histórias únicas, subjetivamente, emergem como figuras subjetivas da personalidade e estão ativamente envolvidas no assunto subjetivo produzido durante o diálogo (GONZÁLEZ REY, 2004b, p. 251).

Compreende-se ainda que, à medida que se desenvolvem novas produções e pesquisas de González Rey e seus colaboradores, diferencia-se o valor do processo dialógico relacional estabelecido entre as pessoas. No ambiente escolar, o processo dialógico relacional estabelecido entre professor e estudante é de suma importância. Mitjáns Martinéz (2004) aponta para a necessidade de reflexão dos professores ao propor atividades que busquem o desenvolvimento dos estudantes em seus processos criativos:

Vemos com preocupação, que com muita frequência, os professores preocupam-se essencialmente com atividades que supostamente poderiam favorecer $o$ desenvolvimento da criatividade, sem ter em conta que a atividade 'não funciona' fora do sistema de comunicação em que está inserida. O sistema de comunicação constitui um aspecto essencial para a compreensão das vivências emocionais que o sujeito experimenta na realização das atividades assim como para a produção de sentidos subjetivos associados a essa atividade (MITJÁNS MARTINEZ, 2004, p. 92).

O pensamento teórico de Gonzalez Rey (2004b, 2007, 2012a) foi se desenvolvendo e a comunicação passou a ser interpretada como um processo humano complexo, assim como a aprendizagem, a criatividade e outros. González Rey (2006) afirma que mais importante que os processos de comunicação são as produções subjetivas que emergem a partir deles:

As emoções são geradas em processos de comunicação que se desenvolvem no jogo de diferentes expressões simbólicas, mas nas emoções produzidas nesses jogos 
produzem seus próprios desdobramentos e se expressam em multiplicidade de formas em relação com outros processos psíquicos (GONZÁLEZ REY , 2006, p. 150).

De acordo com González Rey (1995), a comunicação é a base para a qualidade dos sistemas interativos. Trata-se de processo complexo, sistêmico e processual. Pois, enquanto se comunica, cada um dos interlocutores acessa seu repertório de vocabulário, que pode exigir esforço cognitivo e, para além disso, aspectos afetivos da relação constituída com o outro interlocutor bem como a subjetividade do grupo social ao qual os interlocutores pertencem.

A comunicação deve ser observada como processo vivo, onde emergem sentidos subjetivos configurados na ação de comunicar-se. Por ser processual, desenvolve-se a partir dos contatos relacionais. A comunicação possui caráter contraditório. Por um lado, é constituída por intencionalidade do interlocutor e por outro lado foge da lógica do controle do mesmo, pois como processo subjetivo participam do ato comunicativo sentidos subjetivos produzidos em momentos diversos do qual o interlocutor não controla.

Conforme Mitjáns Martinéz (2004), “o sistema de comunicação constitui um aspecto essencial para a compreensão das vivências emocionais que o sujeito experimenta na realização das atividades assim como para a compreensão da produção de sentidos subjetivos relacionados a essa atividade" (p. 92).

Considerando a comunicação como processo sistêmico, não podem ser levados em conta apenas os momentos comunicativos isolados como a oferta ou obrigatoriedade de modelos de comunicação ou de estabelecimento de uma linguagem entre as pessoas. Há que se considerar as produções subjetivas do indivíduo que estão implicadas no ato comunicacional. Sob essa perspectiva carecem de pesquisas que possam compreender os processos subjetivos envolvidos na aprendizagem de língua do país tanto no aprendizado da modalidade oral como da escrita. Talvez um estudo sob essa perspectiva possa contribuir para um modelo de trabalho favorável ao aprendizado da língua portuguesa escrita pelos surdos.

Para González Rey (1995), o desenvolvimento da comunicação se dá em um processo de retroalimentação, pois é necessário que a comunicação primeiramente se estabeleça para que, posteriormente, haja seu desenvolvimento, e ela é em sua complexidade recursiva e contraditória.

À medida que participa de esquemas comunicativos, o Surdo cria argumentos e retroalimenta seu sistema de comunicação gerando necessidades de novos processos comunicativos. Assim, os surdos que se comunicam com seus familiares apenas através de sinais caseiros, apontação e olhares podem desejar constituir um sistema comunicativo mais elaborado, como postula Vigotsky (1997) que os surdos anseiam por comunicar-se muito mais 
que as crianças ouvintes. Quando esses sistemas não são alimentados permitindo o desenvolvimento dos processos comunicativos e acesso a uma língua, o Surdo pode não desenvolver as potencialidades comunicativas como no caso dos surdos isolados pesquisados por Sacks (1998), Martins (2010, 2015) e Coelho e Cortes (2013), citados anteriormente. Esses mesmos surdos podem configurar-se de forma danosa inscrevendo-se como inacessíveis a processos comunicativos mais elaborados. "Assujeitando-se" à situação, por opção ou por não possuir recursos que permitam a reflexão de sua condição e a possibilidade de romper com esse modelo. Assujeitar-se é não ter postura reflexiva e ativa, o que nem sempre pode ser atribuído ao surdo em tais condições pela ausência da linguagem e significação (TAVARES-SANTOS e MADEIRA-COELHO, 2014).

Conforme Tacca (2006) a comunicação como processo possui níveis e dimensões diferentes, que permite alcançar marcas subjetivas singulares. Nesse sentido, os surdos sinalizadores e não usuários da língua oral podem estabelecer comunicação com pessoas que não utilizam o mesmo código linguístico, mas o diálogo genuíno e, portanto, desenvolvedor, só será possível com pessoas que compartilhem do mesmo código linguístico.

Portanto a comunicação de pessoas surdas pode processualmente desenvolver-se ou não. Independentemente de seu desenvolvimento os momentos de comunicação são subjetivados pelas pessoas surdas, uma vez que se tratam de situações de tensão constante na vida dessas pessoas. Já é postulado que o aprendizado efetivo de uma língua favorece o aprendizado de outra. Portanto, para os surdos falantes de Língua de sinais, os momentos com a comunidade surda podem ser considerados não como um isolamento da coletividade, mas ao contrário, como a possibilidade de retroalimentar e desenvolver a linguagem.

Diante das colocações de González Rey sobre a importância da comunicação como processo complexo que se retroalimenta na medida em que ocorre $(1995,2004 b)$, cabe ainda uma justificativa não referenciada por esse teórico da importância dos contatos do Surdo com a LS que permite compartilhar atualidades, ampliar vocabulário, compreender a língua oficial de seu país e produzir simbolicamente de modo favorável ao ato comunicativo. Situação reconhecida pelos participantes do Congresso de Milão, quando da proibição das línguas de sinais, conforme relato de Lulkin (1998) embasado em Grémion (1991):

As manifestações em favor da supremacia da língua oral, em favor da pureza 'natural' da palavra falada, traduzem o espírito da época, marcado pela racionalidade em oposição à emoção, como se percebe na fala de um congressista italiano: 'Em todas as instituições onde se deseja sincera e eficazmente introduzir o verdadeiro método da palavra, devemos, inicialmente, separar os iniciantes dos outros alunos e, por todos os meios possíveis desenraizar a erva daninha da língua de sinais. A linguagem mímica 
exalta os sentidos e provoca a fantasia e a emoção' ( LULKIN, 1998, p. 37, grifo nosso).

O uso das línguas de sinais entre os surdos, nas comunidades surdas, pode provocar a fantasia, a emoção e as produções simbólicas. Além disso, elas podem ser o espaço para alívio das situações de tensão vividas no cotidiano em ambiente predominantemente ouvinte e consequentemente, para alguns Surdos, é nesses espaços que ocorrem a livre expressão da subjetividade, pois livres da preocupação do como falar e como compreender a mensagem do seu interlocutor, podem falar de seus próprios processos, de suas próprias produções.

Dessa forma, o Surdo participa ativamente de seus processos de comunicação dentro de um sistema social. Essas experiências comunicativas podem forçá-los a criar novos sistemas e modelos comunicativos. Ao longo da história, os homens criaram estratégias para comunicarse em situação de adversidade ou de ausência de um código comum entre os interlocutores. $\mathrm{O}$ enfrentamento dos grupos surdos por uma escola bilíngue trata-se de um momento histórico a partir de suas produções subjetivas sobre os modelos educacionais vigentes. Cabe atentar para o fato de que mais uma vez esse modelo educacional pode ser favorável a um grupo considerável de surdos, mas não pode ser o único modelo favorável ao desenvolvimento de todos eles.

As pesquisas de Silva e Dessen (2001) e Lopes e Coelho (2013) corroboram com o primeiro axioma de Watzlawick “é impossível não se comunicar”. Nesse sentido a comunicação verbal ou não verbal estabelecida "intencional, consciente ou bem sucedida" (WATZLAWICK, BEAVIN \& JACKSON, 1973, p. 45), em forma de palavra, de silêncio, as atitudes, os gestos, o olhar, tudo é comunicado por meio de emoções e expressões que podem dizer tanto ou mais que a linguagem verbal ou sinalizada através da relação interacional desenvolvida, onde os sistemas comunicativos podem ser subjetivados pelo surdo. Daí a importância de desenvolvimento de um trabalho sistemático com as famílias para que se esforcem na comunicação com os filhos surdos (VIADER, 1996; LOPES \& COELHO, 2013).

González Rey (1995) considera que a partir de uma comunicação ampla, aberta e reflexiva é que se desenvolvem os processos de comunicação e, em consequência, os processos de aprendizagem. Em face do exposto é importante considerar que se o estudante ouvinte necessita desse espaço dialógico na escola, essa dinâmica é essencial para a escolarização de pessoas surdas que nem sempre compartilham de interlocutores em outros contextos.

Na linha do pensamento de Tacca (2006), é importante que a comunicação estabelecida na escola ocorra não somente com objetivo de ensino-aprendizagem, mas para a expressão livre e exercício dialógico, para trocas discursivas e argumentação dos estudantes surdos. Desse 
modo, a comunicação cumpre seu papel tornando-se geradora de desenvolvimento. Esse tipo de comunicação torna-se possível quando os dois interlocutores se colocam e se posicionam e portanto, dialogam.

Os momentos privilegiados de diálogo são geradores de sentidos subjetivos nos quais são relacionados sentidos subjetivos produzidos em outros momentos e situações que participam subjetivamente do discurso presente. Alguns surdos encontram espaço para essas trocas dialógicas em grupos de ouvintes, porém, surdos sinalizadores, nem sempre encontram essas possibilidades.

Os espaços criados pelas comunidades surdas podem ser, para alguns surdos, o momento genuíno do diálogo e nem sempre esse espaço relacional é vivido com seus familiares ou com outros grupos sociais composto de pessoas ouvintes. Em algumas situações relacionais entre surdos e ouvintes, a preocupação com as estratégias para a comunicação são tantas que não permitem um diálogo. Ocorrem apenas trocas comunicativas. Portanto, para alguns surdos, as comunidades surdas nutrem a produção de sentidos com vivências e diálogos considerados:

\footnotetext{
"o encontro de almas e só é possível se as pessoas estiverem envolvidas de forma plena e inteira. O Eu constitui-se diante do peso da alteridade. Pessoas abertas para a relação de diálogo e ao encontro comunicam-se tanto por palavras, como no silêncio. Na quietude acontece a comunhão" (TACCA, 2004, p. 110).
}

A comunicação pode ocorrer para além do aspecto verbal, como por exemplo por meio do olhar. Nas relações estabelecidas com o outro é possível perceber olhares intencionais, alguns deles dizem mais que a fala (MADEIRA-COELHO, 2004, 2009).

Em muitos espaços, a condição de Surdo impõe que este seja sujeito dos processos e estratégias comunicativas de modo unilateral. O Surdo fica buscando estratégias para se fazer entender, o que pode ser desenvolvedor de criatividade. Portanto, como já relatado, para alguns Surdos estar com a comunidade surda, onde os interlocutores são usuários de LS pode ser o momento de relaxamento das tensões impostas no cotidiano pelo convívio com ouvintes.

Tais tensões são geradas em momentos como o que tivemos na conclusão dos encontros no campo empírico dessa pesquisa, quando os jovens colaboradores foram convidados para um passeio. Eles optaram por uma ida ao cinema e assim foi feito. Primeiramente foi necessário a procura por um filme legendado, o que não foi possível. Já no shopping, enquanto passeavam, conversavam livremente com a pesquisadora em LS. Em um determinado momento, no elevador, uma senhora com a filha ao observar a pesquisadora e os colaboradores da pesquisa, expressou: - "Coitados! Uma família inteira de mudinhos". Os colaboradores da pesquisa não ouviram a fala da mãe, mas perceberam o olhar que mesmo para a pesquisadora que possui o 
canal auditivo como principal forma de acesso as informações, incomodou, o olhar naquele momento significou mais que as palavras proferidas.

Não estamos julgando a atitude comunicadora, mas o efeito colateral da subjetividade social acerca do surdo e de suas capacidades, da forma que são significados pelo senso comum.

Kelman \& Martins (2012) e Orsoni (2007), postulam situações comuns na vida da pessoa surda, alguns pais que fazem as escolhas pelos filhos assumindo responsabilização por eles e invadindo sua individualidade. Não creditam aos filhos a possibilidade de alcançar autonomia, e não creem que eles possam vir a cuidar de si mesmos. As famílias tornam-se hiper vigilantes e tomam decisões no lugar dos Surdos, protegendo-os de situações de perigo, utilizando assim uma máscara paternalista, considerando, inclusive, como perigosa a convivência com outras pessoas surdas.

A condição de assujeitamento implícita na conduta dessas famílias e profissionais muitas vezes é rompida parcial ou totalmente. Em alguns casos de falecimento dos pais, o surdo pode ser encaminhado às associações para preencher um tempo. O que pode gerar aquisição de língua de sinais e busca de autonomia, essas situações podem ocorrer já na idade adulta e quando "inteligências desperdiçadas" (KELMAN, 2011, p. 186) podem ter se configurado danosamente.

Ainda assim, observam-se casos em que o Surdo após situação de uma vida inteira de assujeitamento, ao ter um contato com outros Surdos, torna-se sujeito de seus processos, como no caso de João, que recebia o Benefício de Prestação Continuada - BPC. Esse dinheiro recebido por ele era administrado pela família e a rotina de João era preenchida com os serviços domésticos. Ele era levado por familiares e vizinhos a consultas médicas ou passeios, pois possuía o Passe Livre com direito à acompanhante, dessa forma, nem ele e nem seu acompanhante pagavam passagem no transporte público. Portanto, sempre que alguém da família ou vizinhança precisava sair de ônibus, João era convocado para liberar o pagamento das passagens. Após a morte da mãe, João com 43 anos, começou a frequentar a Associação de Pais e Amigos do Deficiente Auditivo - APADA e teve seu primeiro contato com a língua de sinais. Nessa instituição, João teve seu primeiro contato com outros Surdos, esses já andavam sozinhos e também teve orientações sobre o Benefício de Prestação Continuada - BPC e outros direitos dos cidadãos. Aprendeu a escrever seu nome e começou a identificar poucas palavras e utilizar alguns sinais da Libras em sua comunicação. Em pouco tempo, João não aceitava mais ser acompanhado por irmãos e passou a administrar os valores do BPC, não acompanhava mais os vizinhos e familiares quando não desejava. 
Vemos claramente um exemplo de emergência de sujeito. Ainda que João não tenha adquirido a Libras nem o português escrito quando jovem, passou a ter conhecimento de mundo e a agir de modo reflexivo, ativo, consciente e emocional. Os familiares tentaram impedi-lo de frequentar a referida associação, percebendo "a péssima influência da instituição" na vida de João, mas ele já sabia ir sozinho e mantinha contato com outros surdos adultos e profissionais da escola através do WhatsApp que usava com os pares.

As postulações disponibilizadas nessa seção permitem assegurar que a adoção de uma língua em detrimento de outra ou mesmo o uso de um e de outro sistema comunicativo pelo surdo ocorre a partir dos "espaços convivências cotidianos" (MADEIRA-COELHO, 2011, p.158), das oportunidades linguísticas que ele tem no decorrer da vida, do modo como a família subjetiva a surdez, do modo como o próprio Surdo configura sentidos subjetivos produzidos em situações de tensão provocadas pelos respectivos processos de comunicação, assim como do modo que se constitui subjetivamente, uma vez que a comunicação é um processo complexo e sistêmico do qual participam aspectos subjetivos produzidos nas mais diversas situações.

A busca da compreensão de processos comunicativos como processos subjetivos exige um olhar amplo que busque reunir o conjunto de aspectos que participam dessa produção. Portanto, a complexidade e a dinâmica não estão apenas na expressão dos indivíduos em um momento específico, mas no caso de pessoas surdas, podem estar articuladas com outras questões, tais como: o contexto do ensurdecimento, os espaços sociais em que a pessoa transita, suas relações familiares, anseios de um porvir, etc. 


\section{CAMINHOS EPISTEMOLÓGICOS E METODOLÓGICOS}

Este trabalho adota a Epistemologia Qualitativa de González Rey $(2002,2005 b$, 2014) desenvolvida diante da necessidade de utilizar um modelo de produção do conhecimento apropriado para compreender a complexidade dos processos da subjetividade. Simultaneamente ao desenvolvimento da Teoria da Subjetividade, González Rey (2002, 2005a, 2014) compreendeu que as metodologias até então constituídas, arraigadas em um modelo positivista de produção do conhecimento, não seriam capazes de adentrar à complexidade que a subjetividade proposta por ele requeria. Conforme González Rey (2002):

\footnotetext{
A epistemologia qualitativa é um esforço na busca por formas diferentes de produção do conhecimento em psicologia que permitam a criação teórica acerca da realidade plurideterminada, diferenciada, irregular, interativa e histórica, que representa a subjetividade humana (p. 29).
}

Ao propor uma nova forma de compreender o humano, fez-se necessária também uma "forma diferenciada" (MITJÁNS MARTÍNEZ, NEUBERN \& MORI, 2014, p. 6) de produzir o conhecimento relativo a este campo. A Epistemologia Qualitativa proposta por González Rey $(2002,2005$ b , 2014) orienta-se pelo método construtivo-interpretativo como forma legítima de investigar os processos da ordem da subjetividade humana.

\subsection{Metodologia}

A Epistemologia Qualitativa caracteriza-se a partir de três princípios (GONZÁLEZ REY, 2005b):

- O caráter construtivo-interpretativo. Nessa proposta, ao contrário das metodologias que primam pela neutralidade do pesquisador, as especulações construídas pelo pesquisador durante o processo investigativo são legitimadas. Isso exige que o investigador assuma o papel de produtor do conhecimento. A postura reflexiva durante o processo de pesquisa permite ao pesquisador dialogar com a teoria e com o momento empírico, conduzindo a investigação como um sistema vivo onde são produzidas ideias. De modo recorrente, na medida em que avança no campo empírico, retorna às bases teóricas que alimentam suas hipóteses e permitem a reflexão sobre a respectiva atuação nesse mesmo campo empírico. O pesquisador, em sua constituição subjetiva, participa ativamente, construindo o conhecimento durante todas as etapas da investigação. A partir do referencial teórico e em contato com as informações e 
ideias produzidas no campo empírico, interpreta e constrói "indicadores que articulam em hipóteses que vão se modificando ou consolidando durante o percurso da pesquisa em função dos novos processos interpretativos e construtivos de informação produzidos" (MITJÁNS MARTÍNEZ, 2014, p. 64). Nesse sentido, a pesquisa, como processo aberto e diferenciado, não se encerra em si mesma e possibilita a produção de novas zonas de sentido, ou seja, "novas interpretações da realidade" (MITJÁNS MARTÍNEZ, NEUBERN \& MORI, 2014, p. 40), que se ampliam na construção de um modelo teórico;

- O caráter dialógico da pesquisa. O momento empírico converte-se em espaço de diálogo onde emergem sentidos subjetivos tanto do pesquisador quanto dos sujeitos da pesquisa. Nessa trama de sentidos, os processos de comunicação tornam-se o meio para a construção de uma relação ativa, que se constitui no processo investigativo. A comunicação direta torna-se a via principal para a conversão do colaborador em sujeito da pesquisa, o que é condição para que se mantenha implicado no problema pesquisado a partir de seus interesses, desejos e contradições, permitindo construir e interpretar sua subjetividade (GONZÁLEZ REY, 2005b);

- O caráter da singularidade dos casos pesquisados. Mais do que perscrutar situações individuais, essa investigação busca compreender os casos singulares, uma vez que a pessoa se constitui da realidade subjetivada e, assim, torna-se singularmente diferenciada. O pesquisador generaliza em relação à construção teórica, mas considera o sujeito da pesquisa em seu caráter histórico. As considerações que o investigador apresenta não podem ser consideradas para todos os casos, mas compreendem um modelo epistemológico que abre novas zonas de sentido sobre o tema estudado.

Esses três princípios articulados entre si embasam esta produção. Esse processo em movimento permitiu o levantamento de hipóteses ou indicadores que foram gerando novos indicadores e ideias em coerência com os primeiros indicadores compondo assim a lógica configuracional.

Esses indicadores tiveram origem na trama produzida pela pesquisadora. De modo que, um indicador "não permite uma afirmação teórica imediata e direta, mas é apenas o primeiro momento do caminho hipotético, dentro do qual os indicadores se convertem em conceitos que alimentam o modelo teórico em curso" (GONZÁLEZ REY , 2013, p. 30). 
As construções da pesquisadora embasaram-se em uma diversidade de aspectos, para além da fala dos sujeitos. Os momentos de observação também foram privilegiados, de modo especial, porque os padrões emocionais associados ao uso da linguagem foram considerados (GONZÁLEZ REY, 2005b). Há um entrelaçamento da subjetividade dos colaboradores da pesquisa tanto durante o projeto piloto realizado no ano de 2014, como no momento seguinte. As impressões e construções foram produzidas no momento empírico e em diálogo com a teoria proposta.

Definiu-se que os encontros seriam registrados por meio de gravações audiovisuais, pois a observação cautelosa das filmagens poderia permitir construir hipóteses. Além disso, poderia apontar o eixo conversacional do encontro seguinte, a elaboração de novos instrumentos ou a reflexão sobre a postura da pesquisadora. A intérprete educacional esteve presente no contexto inicial da pesquisa. Os estudantes eram acompanhados por essa profissional há quatro anos, com uma interrupção de um ano neste período. Cabe ressaltar que a permanência da intérprete educacional, foi uma estratégia da pesquisadora para que os estudantes se sentissem confiantes, porém em momento algum a intérprete educacional exerceu, nesta pesquisa, a função de interpretar os diálogos, pois ficava na sala como sujeito da pesquisa, participando dos mesmos momentos indutores propostos aos estudantes. Posteriormente, dadas as suas respostas e interesse em colaborar, participou ativamente como sujeito de pesquisa o que gerou artigo publicado nos anais do XII EDUCERE (TAVARES-SANTOS e MADEIRA-COELHO, 2015a).

Os sujeitos dessa pesquisa são falantes de língua de sinais. As expressões não-manuais como os movimentos de face, boca, olhos, da cabeça ou do tronco são elementos gramaticais e servem para marcar construções sintáticas ou diferenciar itens lexicais. Deste modo, o olhar atento da pesquisadora foi exigido constantemente. Nessa perspectiva, buscar o que está para além da fala sinalizada dos colaboradores constituiu-se em um dos grandes desafios desta investigação (QUADROS \& KARNOPP, 2004; GESSER, 2009).

Um dos desafios da pesquisadora durante o projeto-piloto, foi a dificuldade em aproveitar os momentos de manifestação dos sujeitos de pesquisa, por nem sempre compreender rapidamente o que estava sendo dito por eles. Uma vez que o vocabulário da pesquisadora em LS permeava mais o universo acadêmico e religioso diferente do vocabulário utilizado na faixa-etária dos colaboradores, isso causou um certo desconforto.

Foi necessário investir na formação em LS, tanto em espaços formais e, principalmente, na convivência com a comunidade surda. Alguns termos usados integram o diálogo diário das pessoas que participam das comunidades surdas e nem sempre estão presentes em espaços 
formais de aprendizagem, como os cursos de Libras. No ano seguinte, na Escola Bilíngue -EB, compreendeu-se que dentre os termos que a pesquisadora não identificava estavam alguns vocábulos próprios dos grupos de adolescentes. Assim, a pesquisadora passou a fazer inferências dentro do contexto e posteriormente tirava dúvidas dos termos com professores ou outros estudantes que pertenciam ao mesmo grupo.

Outro ponto de tensão nessa pesquisa, conforme já observado por Albres e Lacerda (2014) é a dificuldade de "transcrever/traduzir expressões gestuais e corpóreas instrínsecas a Lingua de Sinais" (p. 30), respeitando a produção do sujeito da pesquisa. Ainda que, considerando o método construtivo-interpretativo o pesquisador precisa estar atento ao que o colaborador emitiu e ser capaz de trascrever, sem minimizar a riqueza da produção visual em LS a que o leitor não terá acesso.

Além disso, as expressões do Surdo são tão silenciadas que geram no discurso do senso comum que: "o Surdo dialoga sobre assuntos concretos, mas tratar de assuntos abstratos é muito difícil ou quase impossível". Provocar essa fala silenciada foi um grande desafio para a pesquisadora. Não que os colaboradores não fossem capazes de expressar aspectos de sua subjetividade, mas porque poucos são os que se dispuseram a ouvir/ver essas pessoas em sua integralidade, ao longo de suas vidas. Essa reflexão foi manifesta especialmente na relação com Vanessa ${ }^{8}$.

A seguir serão detalhados o critério de escolha dos participantes, o local da pesquisa, os instrumentos utilizados e a construção do cenário social da pesquisa, que ocorreu sob a forma de projeto-piloto.

\subsection{Critérios de participação}

O único critério para participação na pesquisa foi ser surdo falante de língua de sinais. Inicialmente, chegamos a Berthier para um trabalho de conclusão de uma disciplina do Mestrado. Posteriormente, quando esse foi escolhido como sujeito dessa pesquisa, a pesquisadora se deparou com Vanessa. Tanto Vanessa quanto Berthier tinham um percurso educacional semelhante e uma relação estabelecida entre si. Assim, pode-se observar a singularidade dos casos estudados. Para o ano de 2015, Berthier e Vanessa optaram por matrícula na mesma instituição e foi dada continuidade ao trabalho.

\footnotetext{
8 Nome fictício em homenagem a Vanessa Vidal, modelo surda que representou o estado do Ceará no concurso de Miss Brasil em 2008, é ativista do movimento surdo e autora da autobiografia: A verdadeira beleza.
} 
Além disso, tanto Berthier quanto Vanessa são oriundos de famílias nucleares, compostas por pai, mãe e um irmão, possuem um irmão mais velho do mesmo gênero, sendo que Berthier tem um irmão oito anos mais velho que também é surdo. Vanessa tem uma irmã três anos mais velha que é ouvinte.

O perfil dos dois estudantes foi traçado com embasamento no instrumento leitura de selfie, que será melhor especificado a seguir. Os dados explicitados foram fornecidos pelos próprios estudantes.

\subsubsection{Berthier}

Berthier tem 18 anos, é surdo e solteiro - na comunidade surda, costuma-se manifestar a condição de surdo ou não surdo e se está se relacionando amorosamente com alguém. Nesse caso, a palavra solteiro se refere a não ter namorada. Berthier possui Libras como primeira língua e é aprendiz de língua portuguesa, sendo essa sua segunda língua. Segundo informação oferecida pelo jovem, ele gosta de viajar, passear e se divertir. Nasceu em uma Região Administrativa do Distrito Federal, e vive com os pais e um irmão mais velho, também surdo. Assume uma rotina familiar colaborativa no qual contribui com os afazeres domésticos.

\subsubsection{Vanessa}

Vanessa tem 17 anos, nasceu ouvinte e ensurdeceu no período pré-linguístico, ou seja, antes de adquirir a língua oral de seu país, com mais ou menos um ano de idade. A causa da surdez é desconhecida por ela. É solteira e possui Libras como primeira língua, porém adquiriu tardiamente, uma vez que, o início de sua escolarização foi em escola oralista. É aprendiz de Língua Portuguesa, sendo essa sua segunda língua.

\subsection{Local de pesquisa - Escola Bilíngue Libras português escrito}

A pesquisa iniciou-se em 2014, como projeto piloto, em escola de ensino fundamental do Distrito Federal. No final do ano, os estudantes concluíram o ensino fundamental e mudaram de escola, tendo sido dada continuidade à pesquisa na Escola Pública Integral Bilíngue Libras - Português escrito, a única, até o momento, no DF. Ambas as escolas, a do projeto-piloto e a 
da pesquisa, estão sob a responsabilidade da Secretaria de Estado e Educação do Distrito Federal.

A Escola Bilíngue Libras e Português-Escrito de Taguatinga foi criada pela Portaria $\mathrm{N}^{\circ}$ 171, de 02 de julho de 2013, da SEEDF, em cumprimento à Lei $\mathrm{n}^{\circ} 5.016$ de 11 de janeiro de 2013. O espaço destinado a Escola Bilíngue - EB atualmente, com área de $1.532 \mathrm{~m}^{2}$ funcionou desde 1969 como escola classe ${ }^{9}$, com histórico de atendimento na inclusão de surdos, a partir de 1989. Por reivindicação da comunidade surda (da qual fazem parte os profissionais que atuam na escola), foi transformada, em julho de 2013, em Escola Bilíngue. Por ser recente a mudança do alunado da escola, algumas turmas remanescentes da Escola Classe 21 são exclusivas de estudantes ouvintes. Porém, a diretriz é reduzir, gradativamente, essas turmas.

A proposta da instituição é atender prioritariamente estudantes surdos, tendo Libras como língua de instrução. Está aberta, ainda, a qualquer pessoa que se comunique por meio de Língua de sinais (surdocegos, surdos com implante coclear, CODAs - Children of the Deaf Adults, termo utilizado para designar os filhos ouvintes de pais surdos que dominam a língua de sinais). A escola é aberta a todos que tenham interesse em escola cuja língua de instrução seja Libras.

A instituição atende, nos três turnos, 335 estudantes, sendo 139 surdos, distribuídos entre Educação Infantil, Ensino Fundamental, Ensino Médio e Educação de Jovens e Adultos e Educação Profissional. Essa diversidade justifica-se pelo objetivo de atender os estudantes surdos em todas as etapas e modalidades da educação básica. O Projeto Político Pedagógico (2015) argumenta:

\begin{abstract}
A escolarização plena e a inclusão social dos surdos é a nossa meta! Nos últimos anos, a inclusão dos surdos à sociedade abriu-lhes uma grande possibilidade de exercerem a cidadania. Por isso, todos nós queremos a inclusão, mas não podemos nos esquecer de que a diversidade humana precisa ser respeitada, mesmo nos espaços inclusivos. Uma política de educação inclusiva para os surdos precisa, contudo, levar em consideração suas especificidades linguísticas, culturais e identitárias. A diversidade para a unidade e a diferença para a equidade são marcas importantíssimas para tornar acessíveis as relações sociais e o conhecimento humano adquirido ao longo dos milhares de anos de existência da humanidade.
\end{abstract}

Observa-se que o respeito à diferença linguística dos Surdos nem sempre acontece nas escolas comuns, o que se percebe é um discurso de inclusão e de educação bilíngue em espaços onde o estudante é acompanhado por intérprete educacional. Como se esse profissional fosse o único responsável pela inclusão e aprendizagem dos estudantes. Conforme MEC (2016), a

\footnotetext{
${ }^{9}$ As chamadas Escolas Classes do Distrito Federal são destinadas aos anos iniciais do ensino fundamental.
} 
Escola Bilíngue é uma proposta inovadora, pois originou-se da organização de sua comunidade que para além de propor sua implementação, constrói sua prática pedagógica dentro de pressupostos teóricos que tem como base a pedagogia de projetos. Na política de fomento de projetos de Inovação e Criatividade na Educação Básica do Brasil de responsabilidade do Ministério da Educação - MEC por meio de grupos de pesquisadores liderado por Helena Singer, foi possível mapear 178 organizações educativas no Brasil que possuem propostas de projetos educacionais diferenciados do tradicionalmente convencionado, dentre elas encontrase a Escola Pública Integral Bilíngue (BRASIL, MINISTÉRIO DA EDUCAÇÃO, 2016).

Trata-se da única escola com essas características no Distrito Federal e recebe estudantes de diversas regiões administrativas e entorno. O quadro abaixo ilustra os quantitativos de estudantes matriculados:

Quadro 1 - Quantitativo de estudantes da Escola Bilíngue

\begin{tabular}{|c|c|c|c|c|}
\hline Etapa/Nível & \multicolumn{2}{|c|}{$\begin{array}{l}\text { Quantidade de turma/ estudantes não } \\
\text { surdos }\end{array}$} & \multicolumn{2}{|c|}{ Quantidades de surdos } \\
\hline \multirow{7}{*}{$\begin{array}{c}\text { Ensino } \\
\text { fundamental } \\
\text { Anos iniciais }\end{array}$} & & & \multicolumn{2}{|c|}{$1^{\circ}$ período - 4 estudantes } \\
\hline & $\begin{array}{c}1^{\circ} \text { ano A- } \\
21 \\
\text { estudantes }\end{array}$ & $\begin{array}{c}1^{\circ} \text { ano B- } \\
23 \\
\text { estudantes }\end{array}$ & \multicolumn{2}{|c|}{$1^{\circ}$ ano - 1 estudante } \\
\hline & $\begin{array}{l}2^{\circ} \text { ano } \mathrm{A}- \\
17 \text { estudantes }\end{array}$ & $\begin{array}{l}2^{\circ} \text { ano B - } \\
23 \text { estudantes }\end{array}$ & \multicolumn{2}{|c|}{$2^{\circ}$ ano - 2 estudantes } \\
\hline & $\begin{array}{l}3^{\circ} \text { ano } \mathrm{A}- \\
16 \text { estudantes }\end{array}$ & $\begin{array}{l}3^{\circ} \text { ano } \mathrm{B}- \\
16 \text { estudantes }\end{array}$ & \multicolumn{2}{|c|}{$3^{\circ}$ ano - 8 estudantes } \\
\hline & $\begin{array}{l}4^{\circ} \text { ano } \mathrm{A}- \\
16 \text { estudantes }\end{array}$ & $\begin{array}{l}4^{\circ} \text { ano B - } \\
21 \text { estudantes }\end{array}$ & \multicolumn{2}{|c|}{$4^{\circ}$ ano - 5 estudantes } \\
\hline & $\begin{array}{l}5^{\circ} \text { ano } \mathrm{A}- \\
12 \text { estudantes }\end{array}$ & $\begin{array}{l}5^{\circ} \text { ano B - } \\
13 \text { estudantes }\end{array}$ & \multirow{2}{*}{\multicolumn{2}{|c|}{$5^{\circ}$ ano -8 estudantes }} \\
\hline & $\begin{array}{l}5^{\circ} \text { ano } \mathrm{C}- \\
15 \text { estudantes }\end{array}$ & & & \\
\hline Subtotal & \multicolumn{2}{|c|}{196 estudantes } & \multicolumn{2}{|c|}{28 estudantes } \\
\hline \multirow[t]{4}{*}{$\begin{array}{c}\text { Ensino } \\
\text { Fundamental } \\
\text { Anos finais }\end{array}$} & & & $\begin{array}{l}\quad 6^{\circ} \text { ano } \\
\text { A - } 8 \\
\text { estudantes }\end{array}$ & $\begin{array}{l}6^{\circ} \text { ano B } \\
-7 \text { estudantes }\end{array}$ \\
\hline & & & \multicolumn{2}{|c|}{$7^{\circ}$ ano A - 9 estudantes } \\
\hline & & & \multicolumn{2}{|c|}{$8^{\circ}$ ano $\mathrm{A}-5$ estudantes } \\
\hline & & & \multicolumn{2}{|c|}{$9^{\circ}$ ano $\mathrm{A}-8$ estudantes } \\
\hline Subtotal & & & \multicolumn{2}{|c|}{37 estudantes } \\
\hline Ensino médio & & & $\begin{array}{l}\quad 1^{\circ} \text { ano } \\
\text { A - } 7 \\
\text { estudantes }\end{array}$ & $\begin{array}{r}1^{\circ} \text { ano A } \\
-9 \text { estudantes }\end{array}$ \\
\hline
\end{tabular}




\begin{tabular}{|c|c|c|c|}
\hline & & $\begin{array}{c}\quad 2^{\circ} \text { ano } \\
\text { A - } 9 \\
\text { estudantes }\end{array}$ & $\begin{array}{r}2^{\circ} \text { ano B } \\
-8 \text { estudantes }\end{array}$ \\
\hline & & $\begin{array}{l}\quad 3^{\mathbf{0}} \text { ano } \\
\text { A - } 8 \\
\text { estudantes }\end{array}$ & $\begin{array}{l}3^{\circ} \text { ano B } \\
-3 \text { estudantes }\end{array}$ \\
\hline & & \multicolumn{2}{|c|}{44 estudantes } \\
\hline \multirow[t]{3}{*}{ EJA noturno } & & \multicolumn{2}{|c|}{$\begin{array}{l}1^{\circ} \text { segmento - } 9 \\
\text { estudantes }\end{array}$} \\
\hline & & \multicolumn{2}{|c|}{$\begin{array}{l}2^{\circ} \text { segmento - } 12 \\
\text { estudantes }\end{array}$} \\
\hline & & \multicolumn{2}{|c|}{$\begin{array}{l}3^{\circ} \text { segmento - } 9 \\
\text { estudantes }\end{array}$} \\
\hline Subtotal & & \multicolumn{2}{|c|}{30 estudantes } \\
\hline Total & 196 & \multirow{2}{*}{\multicolumn{2}{|c|}{139}} \\
\hline Total & 335 estudantes & & \\
\hline
\end{tabular}

Fonte: Autora (conforme dados fornecidos, em 15-6-2015, pela SEDF).

\subsubsection{Contextualizando a Escola Bilíngue no momento histórico da educacão do surdo no Distrito Federal.}

Para além do atendimento ofertado na EB, a educação de surdos na Secretaria de Educação do Distrito Federal - SEDF é pautada na perspectiva bilíngue, sendo Libras a primeira língua e o Português a segunda língua, sendo tanto uma quanto a outra, línguas de instrução. Nesses casos, os estudantes são matriculados em classe de educação bilíngue, onde todos são surdos, ou classe de educação mediada, que conta com o professor regente e o intérprete educacional. As turmas têm redução do número de estudantes matriculados, conforme o documento de Estratégia de Matrículas, revisto anualmente. No horário contrário esses estudantes frequentam Atendimento Educacional Especializado - AEE em sala de recursos com professor especializado. Indica-se que as matrículas desses estudantes sejam feitas em escolas polos, para propiciar o convívio entre surdos e facilitar a organização dos serviços (SEDF, 2010, 2016). Sugere-se a proposta de estratégias visuais para a educação das pessoas surdas no DF.

É resguardado às famílias o direito a escolha por filosofia oralista, nesses casos, a criança é matriculada em escola comum, sem a presença de intérprete e recebe o AEE em escola oralista conveniada com essa Secretaria (SEDF, 2010, 2016).

A EB é um espaço novo de atendimento ao surdo na SEDF e no imaginário social dos professores das escolas que trabalham com surdos, existe um discurso de enfrentamento para com essa escola nova e essa nova proposta de atendimento. A pesquisadora atuou durante algum tempo no nível central da SEDF como chefe do Núcleo de Deficiência Sensorial, além disso, 
participa de cursos de formação e tem em sua rede de amigos professores que atuam na educação de surdos do DF. Esse percurso histórico permitiu o acesso a diálogos informais, ou mesmo reuniões formais que contribuíram para compreensão da situação histórica e social em que a EB encontra-se no contexto da educação de Surdos no DF.

A partir da contextualização da EB no cenário da educação de surdos no DF, podem ser apresentados os instrumentos construídos e utilizados para a investigação empírica.

\subsection{Instrumentos da pesquisa}

Na Epistemologia Qualitativa, que orienta esta investigação, os instrumentos são auxiliares e não determinados a priori. Assegura-se a liberdade do pesquisador que, em diálogo constante com o campo empírico e com a teoria, propõe instrumentos já existentes ou criados por ele que possam ser indutores da expressão subjetiva dos colaboradores.

Neste caso, a escolha ou criação dos instrumentos privilegiou o uso de recursos visuais, tendo em vista que os Surdos se relacionam com o mundo a partir de suas experiências visuais. Considerar a surdez como experiência visual "significa que todos os mecanismos de processamento da informação, e todas as formas de compreender o universo em seu entorno, se constroem como experiência visual" (SKLIAR, 1998b, p. 28). Essas considerações, levaram à criação ou adaptação de instrumentos propostos, inclusive durante o encontro.

Com Berthier, o diálogo era fluido e os instrumentos foram criados para confirmar ou suspender alguma hipótese levantada a partir dos diálogos. Com Vanessa porém, o diálogo não foi tão fluido, o que suscitou a criação de uma variedade de instrumentos que permitissem a livre expressão da mesma. Em agosto de 2015, houve intenção de não permanecer com Vanessa na investigação. Porém, essa parecia gostar dos encontros da pesquisa. Apenas em outubro, quase ao final da pesquisa houve um encontro expressivo dessa colaboradora.

Para González Rey (2002), no processo dialógico entre pesquisador e colaborador, emergem sentidos subjetivos essenciais para a qualidade das informações produzidas no processo de investigação. Por esse motivo, o sistema conversacional destacou-se ao longo da pesquisa.

De acordo com González Rey (2005b), a conversação em momentos informais é instrumento legítimo, que permite a expressão do sujeito implicado na pesquisa sem o direcionamento de outros instrumentos. Exige uma postura atenta, flexível e criativa do pesquisador, que, no processo dialógico, pode conduzir o sujeito da pesquisa à reflexão e à emergência de novos sentidos subjetivos. Nesse processo, o pesquisador rompe com os 
fundamentos dos pressupostos da psicologia comportamental do modelo estímulo-resposta e "desloca-se do local central das perguntas para integrar-se em uma dinâmica de conversação que toma diversas formas de um 'tecido de informações' que implique com naturalidade e autenticidade o participante" (GONZÁLEZ REY, 2005b, p. 45).

Assim, o diálogo permeou a trajetória investigativa - iniciando-se em temas gerais e partindo para assuntos mais específicos - de forma isolada ou acompanhada dos seguintes instrumentos:

\subsubsection{Complemento de frases}

Criado inicialmente como teste projetivo, por volta dos anos 70, González Rey e Mitjáns Martinéz empregaram o complemento de frases como instrumento de pesquisa. Trata-se de indutores curtos para serem completados pelo colaborador da pesquisa. Nas produções sob a perspectiva da Epistemologia Qualitativa é adotado com frequência.

O complemento de frases, nesta investigação, procurou responder a dois objetivos, o primeiro era compreender como os familiares se relacionam com o filho surdo. Nesse caso, o instrumento foi aplicado em sua forma original, ou seja, escrito. O segundo objetivo era compreender elementos da subjetividade dos participantes da pesquisa. Nesse caso, foi adaptado para vídeo em Libras.

Na etapa inicial deste trabalho, o complemento de frases não se mostrou eficaz. Um dos sujeitos conseguia expressar-se por escrito, mas demorava para escrever as respostas e procurava a pesquisadora para referendar os termos da língua portuguesa. A pesquisadora propôs atuar como escriba e o colaborador acompanhava se os termos em português se adequavam ao que ele falara em libras.

No caso da outra colaboradora, esta apresentou muita dificuldade para escrever. A pesquisadora necessitou atuar como escriba, iniciando a frase em libras e escrevendo em português a frase sinalizada por ela. O esforço para escrever em língua portuguesa pode ter dificultado a livre expressão da jovem participante. A partir dessa constatação, a pesquisadora adaptou a proposta, pois percebera que o instrumento em seu formato original acabara por converter-se em um questionário.

Os Surdos podem expressar-se por meio da escrita, mas, nesse caso, compreendeu-se que o pensar no vocabulário a ser utilizado acarretou a perda da fluidez e a consequente perda da força indutora da expressão subjetiva dos colaboradores. 
Ulteriormente, a pesquisadora adaptou o complemento de frases. Fez a filmagem de vídeos com as frases iniciadas em LS para que cada participante desse continuidade à frase também em LS. Todo o processo foi filmado e depois retomado pela pesquisadora para diálogo. Esse novo modelo proposto, tornou-se elemento significativo para esta investigação, uma vez que respeitava a visualidade constituidora dos sujeitos de pesquisa.

\subsubsection{Dramatizacão}

No dia em que a pesquisadora planejou o complemento de frases escrito e percebeu sua ineficácia para o objetivo proposto, uma dramatização de um dia do cotidiano dos sujeitos da pesquisa foi proposta, para buscar compreender os principais interlocutores dos estudantes e as relações interacionais estabelecidas.

Embora surdos constantemente se comuniquem por expressões faciais, pelo corpo e pela língua de sinais e desenvolvam o talento para se expressar, por meio da dramatização, das narrativas e da contação de histórias (STROBEL, 2009), a expressão de si mesmos, o acesso à dimensão pessoal de elaborações singulares parece não fazer parte das dinâmicas comunicativas dos colaboradores. Enquanto Berthier expressa: "Não gosto de falar de sentimentos", Vanessa se manteve tímida, durante boa parte da pesquisa.

Nesse sentido, solicitou-se que cada um mostrasse sua rotina diária desde o momento em que acordava até o horário que dormia. Para essa dramatização, cada um dos colaboradores poderia assumir o papel de si mesmo ou o de outro personagem com quem convivia.

Inicialmente, fizeram uma representação rápida e simples. A pesquisadora, então, dramatizou sua rotina, desde a hora que o despertador tocava até a hora que se deitava e ficava no celular. Ela já havia visualizado no Facebook dos estudantes postagens feitas durante a madrugada e aproveitou para verificar quem eram os interlocutores desses momentos. A pesquisadora, em sua dramatização, assumia vários papeis, desde suas filhas, vizinhos e pessoas com as quais se relacionava no decorrer de um dia. Após atuação da pesquisadora, os participantes assumiram os vários personagens com quem interagiam no decorrer do dia.

\subsubsection{Sessão de vídeo}

As imagens são registros que carregam o significado de um momento histórico (LOIZOS, 2002) e, portanto, podem revelar sentidos subjetivos produzidos naquele instante, que podem ser evocados com a observação daquela imagem. Nesta construção, as sessões de vídeo foram utilizadas em dois momentos. 
No primeiro, objetivava-se o relato de circunstâncias conflituosas de seus processos comunicativos e os sentimentos que emergiam nesse tipo de episódio. A pesquisadora exibiu filme ${ }^{10}$, de gênero comédia, que abordava a dificuldade de comunicação entre dois indivíduos. $\mathrm{Na}$ oportunidade, os participantes relataram as situações vividas em que não foram compreendidos e como haviam se sentido. Foi solicitado que os estudantes ilustrassem situações da dificuldade de comunicação e como desejavam que esse processo comunicativo tivesse acontecido.

Na segunda ocasião em que a sessão de vídeo foi proposta, a pesquisadora tinha como objetivo compreender o processo de aquisição de Libras por parte dos colaboradores da pesquisa. $\mathrm{O}$ vídeo apresentado abordava a aquisição tardia de linguagem ${ }^{11}$. $\mathrm{O}$ filme contava a história de Patrick Otema, um jovem surdo de Uganda, que se comunicava, minimamente, por sinais caseiros. Narrava, ainda, o primeiro contato de Patrick com outros surdos. Após o filme, dialogou-se sobre a vivência de situações semelhantes vivenciadas por eles.

\subsubsection{Publicacões em rede social}

Nesta investigação, utilizou-se o Facebook com os seguintes objetivos:

- Observar as situações vividas pelos colaboradores;

- Verificar o modo como se expressam nas redes sociais e os respectivos interlocutores;

- Manter o cenário social da pesquisa durante as férias e greve escolares, uma vez que a investigação iniciou-se em 2014 e foi concluída apenas no ano seguinte;

- Introduzir diálogos entre a pesquisadora e os colaboradores da pesquisa, a fim de confirmar hipóteses construídas.

Como já pontuado anteriormente, as redes sociais permitem a publicação de textos contínuos ou descontínuos, o que torna um facilitador para os surdos, além da ausência do rigor da escrita e da disponibilidade do recurso do corretor ortográfico.

Além do Facebook, durante o curso da pesquisa, houve a necessidade de criação de um grupo no WhatsApp, para combinar os encontros e confirmar a presença dos estudantes na escola. Esse grupo tornou-se também espaço para conversas espontâneas e desabafos. O nome do grupo era: "Família pesquisa" e foi criado por um dos participantes a partir de um diálogo onde cada um relatou problemas vividos no âmbito familiar. Na ocasião, surgiu a brincadeira

\footnotetext{
${ }^{10} \mathrm{https}: / / \mathrm{www}$. youtube.com/watch? $\mathrm{v}=\mathrm{b} 8 \mathrm{bP} 08 \mathrm{ryzZs}$

${ }^{11} \mathrm{https}: / / \mathrm{www}$.youtube.com/watch?v=UtwLBunFCCQ
} 
entre a pesquisadora e os participantes da possibilidade de os três morarem juntos para fugir dos problemas enfrentados no cotidiano familiar. A brincadeira foi mantida durante toda a investigação. A pesquisadora aproveitava para questionar os pontos positivos e negativos dessa possibilidade. A brincadeira de nova família foi mantida pela pesquisadora com intencionalidade de provocar a reflexão sobre as responsabilidades de cada um nas relações familiares na dimensão do real.

\subsubsection{Desenho}

O desenho constituiu-se em indutor eficaz para a expressão dos colaboradores que conseguiram registrar as expressões faciais do personagem que representavam, permitindo um desdobramento eficaz da conversação. Foi utilizado para registro de produções que emergiram com o uso de outros instrumentos. O desenho também foi utilizado para tentar substituir os registros escritos que foram observados como ineficazes para um dos sujeitos da pesquisa.

Em uma ocasião na EB, foi feita uma proposta de atividade escolar que sugeria o registro da significação da LS para cada um dos estudantes. A riqueza do desenho produzido para exposição levou a pesquisadora a fazer alguns questionamentos sobre o mesmo e depois considerá-lo como instrumento de pesquisa.

\subsubsection{Leitura de um Selfie}

A fotografia possibilita a expressão da realidade, permite o registro de um tempo e espaço únicos (GURGEL, 2015). A selfie é um tipo de fotografia produzida, um autorretrato, que pode ser utilizada como instrumento de pesquisa, para autoconhecimento e promoção da interação dos colaboradores da pesquisa. Nessa investigação, o instrumento leitura de selfie foi criado com o objetivo de verificar como cada participante se reconhece e se inscreve e o que diz de si mesmo.

Inicialmente, solicitou-se aos estudantes que fizessem selfies livremente, com o uso da máquina fotográfica e, depois, assumissem a foto como se ela falasse. Posteriormente, requereuse que, olhando a própria imagem, dissessem o que viam como se fosse a foto se apresentando para alguém. Foi lançado o desafio pela pesquisadora: [EU NÃO CONHEÇO VOCÊ. CHEGUEI AGORA E VI A FOTO, ELA CRIOU VIDA E COMEÇOU A FALAR. QUEM ELA É? O QUE A FOTO VAI ME DIZER?].

Esse instrumento foi utilizado em situação em que a pesquisadora estava observando a aula e foi convidada a assumir a turma, em substituição a um professor regente da classe. $\mathrm{Na}$ 
ocasião, ela propôs esse instrumento do qual participaram os seis alunos da turma, mas, para efeito da construção da informação foram considerados unicamente a expressão dos dois colaboradores da pesquisa.

Berthier falou de si da composição familiar, do momento do ensurdecimento e dos processos de escolarização. Vanessa também falou de si, mas não conseguia olhar para a câmera como fora recomendado. Enquanto se apresentavam a pesquisadora fazia intervenções provocativas. [O QUE FAZ VOCÊ FELIZ? QUAL O MOMENTO MAIS TRISTE DE SUA VIDA?].

\subsubsection{Observacão participante}

De acordo com Oliveira (2010), a observação participante ocorre quando o pesquisador interatua com o grupo pesquisado em situações formais ou informais, convertendo esses momentos em fonte de diálogo. Para além de observar, a pesquisadora questionou ações dos colaboradores da pesquisa.

Nesta investigação, a observação permitiu compreender, em momentos diversos, expressões de subjetividade dos colaboradores da pesquisa. Ocorreu na escola, tanto em sala de aula quanto em momentos informais, como horários de almoço e intervalo das aulas.

A observação pôde ser experimentada, ainda, em eventos extracurriculares, como passeio ao clube, apresentação no evento de Experiências Exitosas na Educação Especial, Feira de Ciências e no I FestSurdo da Escola Bilíngue. A pesquisadora, gradualmente, integrou-se nas atividades escolares e, na relação com os profissionais, sendo convidada ou se dispondo a participar de atividades extracurriculares.

No presente estudo, a observação foi empregada para perceber aspectos da subjetividade social daquele espaço, o modo como os sujeitos de pesquisa se relacionavam com os colegas e com os professores, bem como os processos de comunicação utilizados por eles. Os acontecimentos significativos da observação foram registrados em diário reflexivo, bem como os sentimentos que acompanharam a trajetória da pesquisadora e os indicadores levantados por ela.

Além da participação em sala, reunia-se no horário de almoço, com os alunos e professores. Os momentos livres de atividade como o horário de almoço, intervalo e entrada e saída dos alunos, foram os mais propícios para conversas informais, tanto com os sujeitos da pesquisa quanto com os professores, funcionários e pais de alunos. 


\subsubsection{Escolha de gravuras}

Foi um instrumento utilizado em dois momentos. No primeiro, foram apresentadas revistas e solicitou-se a escolha de cinco gravuras que os representasse naquele momento. Em seguida, deveriam narrar o motivo de sua escolha. $\mathrm{O}$ objetivo era compreender os interesses dos colaboradores da pesquisa.

No segundo momento, foram oferecidas várias gravuras e Vanessa e Berthier deveriam observá-las e falar o significado de cada uma. Em seguida, deveriam escolher uma delas conforme a palavra chave dada. Assim escolhiam gravuras que representassem cada palavra ou expressão dada pela pesquisadora, e relatavam o ensejo da seleção. O objetivo era conhecer como os participantes se relacionam em contextos familiares e educacionais. No Apêndice II, encontram-se as gravuras, assim como os termos solicitados para que representassem.

\subsubsection{Situação de conflito}

Consiste em instrumento "indireto, amplo e flexível" (BEZERRA, 2014, p. 97). No caso deste estudo, foi utilizado com situações conflituosas passíveis de ocorrer em situações familiares e sociais.

Esse instrumento surgiu da necessidade de concluir o trabalho de investigação e verificar algumas das hipóteses criadas a partir dos indicadores.

O instrumento foi proposto por meio de cenas que mostravam situações fictícias vividas no cotidiano. No primeiro cenário, a pesquisadora apresentou a caricatura que representava cada um dos participantes com animação de stop motion. Ao apresentar cada situação de conflito, questionava: [VOCÊ CHEGA NESSE AMBIENTE E NÃO CONHECE NINGUÉM, COMO REAGE? COMO SE SENTE?]. Foram criadas cinco situações conflituosas para que os participantes se posicionassem a respeito. A primeira situação mostrava o sujeito da pesquisa chegando em ambiente onde todos sinalizavam. O segundo mostrava o sujeito da pesquisa chegando em ambiente onde todos se comunicam oralmente. $O$ terceiro mostrava situação onde o colaborador da pesquisa chegava em ambiente familiar e, por último, havia um cenário com ambiente dividido em dois grupos, um de pessoas sinalizantes e outro de pessoas que se comunicavam oralmente. O instrumento em sua integra encontra-se no apêndice III (em vídeo). 


\subsubsection{Filmagem: Esse sou eu, essa é minha história}

Os sujeitos da pesquisa foram convidados a escolher fotos ou vídeos de momentos significativos de sua biografia e produzir filmagem, com fotos, cenários e personagens, de sua história de vida. O filme foi produzido em 15 dias e, após, foi apresentado, em diálogo com a pesquisadora.

O uso desse instrumento foi muito expressivo e ocasionou memórias de momentos significativos para os colaboradores. No dia da apresentação do vídeo, cada colaborador estava livre para trazer objetos, fotos, textos ou algo significativo que contasse um pouco de sua trajetória. Uma produção escrita trazida por Berthier chamou atenção da pesquisadora e por isso será relatada a seguir.

\subsubsection{Produção escrita}

A produção escrita, nesta investigação, consistiu de um abaixo-assinado produzido por Berthier. Na ocasião, a pesquisadora solicitou que trouxessem objetos ou fotos de momentos marcantes, caso desejassem. O abaixo-assinado, produzido em 2013, se referia a um momento significativo da vida do estudante e possibilitou um diálogo dinâmico. Será contextualizado o momento em que ocorreu o abaixo-assinado - conforme relato de Berthier e de sua mãe - para elucidação da escolha do documento como instrumento de pesquisa.

Desde os primeiros meses de vida, Berthier recebera estimulação para aquisição da língua portuguesa oral por meio de treinos. A família fora orientada à estimulação da fala, evitando o contato com a Língua de Sinais em qualquer ambiente. Apesar disso, Berthier aprendeu Libras com o irmão, também surdo, e com os colegas da escola em que recebia atendimento educacional especializado- AEE. Os estudantes faziam uso da Libras na escola, porém sua utilização não era recomendada pela instituição educacional. A partir do $6^{\circ}$ ano, com o aumento considerável de disciplinas na escola, a família solicitou acompanhamento de intérprete educacional durante as aulas, sem abrir mão da estimulação oral.

Posteriormente, incomodado com a obrigatoriedade do uso da língua portuguesa oral no AEE, Berthier reivindicou através das redes sociais o uso de LS, como forma de comunicação e língua de instrução naquela instituição, liderando um abaixo-assinado. A reivindicação de Berthier não exigia o uso exclusivo de LS, mas a possibilidade de escolher sua forma de comunicação, que poderia ser tanto em LS quanto em português oral. Observa-se que ele não exclui a possibilidade de comunicar-se em português oral, porém exige o direito de escolha entre essa forma de comunicar-se e a Libras. 
Após o abaixo-assinado e as manifestações em redes sociais, a escola sugeriu o desligamento definitivo do estudante da escola onde recebia AEE, sob a alegação que sua escolha linguística não se alinhava ao modelo adotado na instituição.

$\mathrm{O}$ estudante não aceitou passivamente o desligamento, insistindo para continuar o atendimento na instituição, onde estudava desde bebê e onde estavam seus amigos. A exigência de Berthier causou várias articulações até definir-se que ele receberia o atendimento nessa escola, mas não poderia mais fazer as refeições lá, como anteriormente.

O texto produzido por ocasião do abaixo-assinado e os desdobramentos dessa ação serão utilizados na construção da informação.

No quadro a seguir, explicitam-se os instrumentos utilizados com cada colaborador da pesquisa.

Quadro 2 - Instrumentos com cada participante

\begin{tabular}{|c|c|c|c|}
\hline \multirow{2}{*}{ Instrumento } & \multicolumn{3}{|c|}{ Participantes } \\
\cline { 2 - 4 } & Berthier & Vanessa & Familiares \\
\hline Complemento de frases escrito & $\mathrm{X}$ & $\mathrm{X}$ & $\mathrm{X}$ \\
\hline Facebook & $\mathrm{X}$ & $\mathrm{X}$ & \\
\hline Desenho & $\mathrm{X}$ & $\mathrm{X}$ & \\
\hline Leitura de selfie & $\mathrm{X}$ & $\mathrm{X}$ & \\
\hline Dramatização & $\mathrm{X}$ & $\mathrm{X}$ & \\
\hline Sessão de vídeo & $\mathrm{X}$ & $\mathrm{X}$ & \\
\hline Complemento de frases em & $\mathrm{X}$ & $\mathrm{X}$ & \\
\hline vídeo & & $\mathrm{X}$ & \\
\hline Situação de conflito & $\mathrm{X}$ & $\mathrm{X}$ & \\
\hline Escolha de gravuras & $\mathrm{X}$ & & \\
\hline Esse sou eu, essa é minha & $\mathrm{X}$ & $\mathrm{X}$ & \\
\hline história & & & \\
\hline Abaixo-assinado & & & \\
\hline
\end{tabular}

Fonte: Autora, a partir de (BEZERRA, 2014) 


\subsection{Construindo o cenário social da pesquisa}

A construção do cenário social da pesquisa é essencial na epistemologia adotada, por possibilitar que o colaborador esteja implicado no processo investigativo, participando de modo ativo. "Seria como construir um cenário teatral com luzes, cores, mobílias e texturas, onde seja possível estabelecer uma relação comunicacional entre atores e espectadores" (ROSSATO, MARTINS \& MITJÁNS-MARTINEZ, 2014, p. 41). É nesse espaço dialógico que o colaborador da pesquisa é convidado a subir ao palco como protagonista, deixando de ser mero espectador.

O projeto piloto, realizado no segundo semestre de 2014, constituiu-se como construção do cenário social da pesquisa, objetivando tanto uma aproximação entre a pesquisadora e os colaboradores quanto a experienciação do novo papel de pesquisadora que a autora do trabalho precisava assumir. Foram cinco encontros na escola. Além deles, houve um anterior, na residência de Berthier, com ele e sua mãe.

Para isso, a investigadora visitou três vezes a escola, de modo a articular o horário propício para os encontros ou para conversar com os estudantes e profissionais da instituição. Em outro momento, convidou os participantes da pesquisa e providenciou a autorização dos familiares, por meio de Termo de Consentimento Livre e Esclarecido - TCLE. Também houve a necessidade de autorização junto à direção da escola e outras instâncias da Secretaria de Educação do Distrito Federal - SEDF.

No momento inicial da pesquisa, os estudantes não tinham muita clareza sobre a participação na investigação. A pesquisa garantiu que poderiam avaliar o procedimento e os objetivos do trabalho para, somente após essa etapa, confirmarem se colaborariam ou não com a investigação.

Na perspectiva epistemológica adotada, o pesquisador dá o máximo de informação aos colaboradores para que se comprometam com o processo de produção do conhecimento. Assim, foi apresentado o objetivo da pesquisa - que seria compreender a vida de pessoas surdas e como se relacionavam. Um dos colaboradores questionou:

Berthier: [COMPREENDER O QUÊ DA VIDA DO SURDO?] (Desconfiado) Pesquisadora: (fez o sinal de "SENTIMENTO") [QUERO COMPREENDER OS SENTIMENTOS DE VOCÊS].

Berthier: [NÃO GOSTO DE FALAR DE SENTIMENTO, NÃO] (com olhar desanimado).

Pesquisadora: [TAMBÉM NÃO GOSTO, ÀS VEZES, É DIFÍCIL. VAMOS COMBINAR ASSIM: COMEÇAMOS A FALAR DE SENTIMENTO E DEPOIS CADA UM DECIDE SE QUER CONTINUAR OU NÃO. PODE SER?] 
Os encontros aconteceram durante os dois primeiros horários, às sextas-feiras, no horário de aula de Parte Diversificada do Currículo - PD, na qual as atividades costumam ser livres e, portanto, não haveria prejuízo do componente curricular. O período de tempo de cada encontro foi de, aproximadamente, $1 \mathrm{~h} 40 \mathrm{~m}$.

Na construção do cenário de pesquisa, momento que objetivava apresentar a pesquisa aos colaboradores, importava a criatividade da pesquisadora em conduzir o encontro para envolver os colaboradores a participar da investigação.

Nesse contexto, aplicou-se o instrumento Pizza do Cotidiano, de autoria da pesquisadora, que consiste em discos de emborrachado, divididos em tamanhos diferentes, utilizados nas aulas de matemática para ensinar frações. A ferramenta foi útil para conhecer o cotidiano dos estudantes e os sentimentos emergentes durante as atividades executadas.

Nessa atividade, participaram a pesquisadora, a intérprete e os estudantes. Cada um falou sobre suas preferências alimentares, quantificando-as com peças do disco de fração que, em seguida, foram comparadas às atividades do dia-a-dia. As fatias maiores representaram as atividades preferidas e, as menores, as menos prazerosas, constituindo um gráfico no modelo pizza. Na sequência, foi feito o registro escrito, com o desenho do disco contendo a distribuição das preferências, trabalho acompanhado ininterruptamente por diálogo.

Chamou a atenção da pesquisadora o fato de terem aparecido no desenho elementos não anunciados anteriormente, como, por exemplo, quando Vanessa representou o cuidado com seu afilhado, não expressado antes em sua explanação. Para encerrar o encontro, serviu-se lanche com pizza e suco, além de conversarem informalmente sobre temas diversos, inclusive a avaliação do encontro, que havia sido uma forma de falar sobre os "sentimentos". Por último, cada um manifestou-se individualmente sobre a adesão à pesquisa. 


\subsection{Metodologia da construção da informação}

O texto sobre a construção da informação neste trabalho se refere a dois momentos diferenciados que são complementares. Decidimos por apresentá-los em capítulos separados tendo em vista o diferente escopo da análise que cada um deles exigiu da pesquisadora.

Apresenta-se inicialmente, no Capítulo 4 as construções referentes aos valores, representações e crenças que buscam caracterizar aspectos constitutivos da dinâmica da Escola Bilíngue, tanto em relação à sua organização interna, relações sociais e dinâmicas vivenciais, bem como levantar indicadores sobre a repercussão que a mesma tem na rede púbica de ensino do DF. A construção é, pois, descritivo-interpretativa.

Em seguida no Capítulo 5, apresento a construção-interpretativa sobre a dinâmica subjetiva de cada um dos sujeitos de pesquisa, Berthier e Vanessa, e o entrelaçamento entre a constituição subjetiva dos dois estudantes. Esse capítulo está marcado pelas construções da pesquisadora a partir das diferentes formas de expressões dos dois colaboradores. Nota-se que esse processo de construção não segue a ordem cronológica e linear da expressão dos sujeitos, mas, à medida que ocorreram, foram suscitando hipótese na pesquisadora que levaram a novos questionamentos e posturas diante dos colaboradores desta pesquisa. As hipóteses levantadas se constituíram como um modelo teórico em constante desenvolvimento, onde foram levantados indicadores que se entrelaçaram com a teoria de modo indissociável.

\section{SOBRE A ESCOLA BILÍNGUE}

A permanência da pesquisadora por aproximadamente 100 horas na instituição e a relação já existente e/ou criada a partir dessa pesquisa favoreceu o desenvolvimento de uma relação dialógica entre a pesquisadora e os profissionais da instituição que motivaram a inserção deste tópico sobre a Escola Bilíngue. Busca-se, assim, caracterizar aspectos constitutivos da dinâmica desta unidade de ensino, tanto em relação à sua organização interna, relações sociais e dinâmicas vivenciais, bem como levantar indicadores sobre a repercussão que a mesma tem na rede púbica de ensino do DF. Por meio da descrição de diálogos, situações cotidianas e interações pedagógicas que caracterizam esse contexto social procura-se evidenciar aspectos culturais que circulam nas vivências cotidianas na escola; crenças e representações que o sistema educacional organiza sobre essa instituição; e, concepções em relação à aprendizagem das pessoas surdas. 


\subsection{Escola Bilíngue - "A escola dos sonhos"?}

Essa representação geral que idealiza a EB como "escola dos sonhos" será apresentada a partir das diferentes perspectivas de pessoas que, de alguma forma, frequentam aquele contexto. Há espaço inclusive para o contraditório, quando o sonho não se situa exatamente como a solução dos problemas da aprendizagem e o desenvolvimento da pessoa surda.

a) Surdos visitantes:

Os Surdos da comunidade visitam constantemente a EB. Em geral, são adultos sinalizadores que não são matriculados, mas circulam pela sala dos professores, no intervalo ou em eventos culturais. Eles frequentam a instituição para conhecer a escola, para compartilhar experiências, para entrevistar professores, rever amigos ou pedir acompanhamento de ouvinte como intérprete em questões pessoais, profissionais e acadêmicas e com isso, acabam contribuindo com pesquisas e projetos.

Esses surdos adultos configuram esse espaço como o espaço educacional favorável à aprendizagem tanto em suas falas quanto em seu olhar para as crianças ali matriculadas. Manifestam certa inveja e admiração pela oportunidade que eles mesmos não tiveram de poder ter estudado ali. Em uma ocasião ao encontrar um surdo adulto, que a pesquisadora conhecia de outro espaço, ela questionou:

\footnotetext{
Pesquisadora: [OI, VOCÊ ESTÁ ESTUDANDO AQUI A NOITE?].

Ao que o Surdo respondeu: [EU SONHO].

A pesquisadora interrompeu: [SE VOCÊ SONHA, PORQUE NÃO VEM ESTUDAR AQUI?]

Jovem surdo: [JÁ PASSOU, AGORA É TEMPO DE TRABALHAR E SUSTENTAR FAMÍLIA, PAGAR ALUGUEL, COMIDA. QUANDO EU ERA CRIANÇA NÃO TINHA ESCOLA ASSIM].
}

A fala do jovem surdo é autoexplicativa, mostra que para ele esse espaço é representado como a "escola dos sonhos", desejando ter estudado ou ainda poder estudar nessa escola. Porém, segundo ele, os compromissos por ele assumidos no momento não lhe permitem.

A língua de sinais só começou a entrar para a sala de aula a partir da década de 1990 e propostas como a da Escola Bilíngue ainda permanecem como um desafio para a maioria dos surdos brasileiros que sonham como uma educação que respeite seus marcos linguísticos.

Esse espaço de sonho também parece ser configurado como espaço de denúncia. Durante o período da pesquisa, dois estudantes surdos de outras unidades de ensino, quando 
tiveram problemas em suas respectivas escolas, recorreram à EB, como se esta fosse um espaço para denúncias. Uma professora me explicou que, nesses casos, por questões éticas, eles acolhem os estudantes de maneira imparcial. Quando os estudantes surdos chegam dessa forma, é feita a escuta sensível, sem a pretensão de ação para modificar a realidade das escolas de origem dos alunos que estão reclamando. Observa-se, no entanto, se o estudante está faltando à escola para visitar a EB.

Os estudantes demonstram identificar-se de tal modo com a EB a ponto de acharem que suas queixas encontrarão guarida e defesa em relação a outros coletivos escolares. O que a fala da professora deixa entrever é que, apesar de a escola não assumir o papel pretendido pelo aluno queixoso, a EB permanece como espaço de acolhida, podendo ser este o motivo que leve os estudantes a representá-la desta forma.

b) Estudantes da própria escola

Apesar da representação genérica como escola idealizada, “dos sonhos”, há espaço para a contradição. Considero que a EB seja, para alguns, a "escola dos sonhos" porque rompe com o modelo oralista e propicia um espaço de liberdade e incentivo ao uso da língua de sinais. Além disso, está organizada como um espaço de convivência entre surdos adultos e crianças. Fatores históricos também intervêm, pois a EB é o resultado de enfrentamentos da comunidade surda na qual participaram os professores e os gestores da escola.

Apesar disso, os professores relataram a situação de uma estudante da EB que optou por transferir-se para outra escola, tendo em vista que considerava o seu currículo "fraco". Esse fato demonstra que apesar da EB constituir-se genericamente como "escola dos sonhos", lá também aparece espaço para a divergência. Em determinada ocasião, quando a ex-aluna foi visitar a escola, os professores a receberam carinhosamente e perguntaram sobre seu desenvolvimento. A pesquisadora estava na sala dos professores e pôde acompanhar o diálogo:

Professora surda: [OLÁ, LEGAL QUE VEIO VISITAR ESCOLA BILINGUE]. Aluna surda: (em português oral e sinalização simultânea): Sinto saudades de vocês, mas estou gostando da nova escola. Lá é difícil mesmo, minha mãe falou que vou passar no vestibular. Só é ruim quando falta intérprete. (a conversa transcorreu sobre assuntos relacionados à nova escola e os problemas da inclusão).

A fala da aluna, quando diz "só é ruim quando falta intérprete", revela que ela ainda sente falta daquilo que a escola ressalta como relevante, o uso disseminado da língua de sinais. Entretanto, o fato de se comunicar oralmente parece suprir carências na área da comunicação e 
consequentemente na interação na outra escola. Para a ex-aluna, a EB é também representada pelo que lhe falta, um “ensino difícil” capaz de dar conta de "passar no vestibular".

c) Pesquisadores e estudiosos

Por motivos diferentes daqueles expressados pelos surdos visitantes, os pesquisadores e estudiosos da educação de surdos também reconhecem a escola como acolhedora. Nos seus relatos, eles dizem que podem experimentar, nesse espaço, a realização de um sonho: a concretização de uma luta por ações políticas com as quais estão comprometidos. Muitos profissionais de outros estados e países visitam a escola para conhecer seu funcionamento, bem como os trâmites legais de sua institucionalização com o objetivo de facilitar a implantação de escolas bilíngues em seus estados de origem. Referendam-se, também, pelo prestígio social que a abertura para o fazer científico confere ao local.

d) Os professores da escola

Os professores da escola representam esse espaço educacional como uma conquista de um grupo, como um privilégio. Nesse sentido, o PPP- Projeto Político Pedagógico - escrito pelos profissionais da escola quando se refere às próprias potencialidades, aponta: "Equipe de professores qualificados e comprometidos". Os professores da EB se intitulam, portanto, qualificados. Não só no PPP, mas em momentos de reunião e mesmo nas entrevistas, pode ser visto um discurso de autovaloração, expressando a compreensão do engajamento desses professores com a docência e sua profissionalidade. O diálogo a seguir, que ocorreu entre uma professora e a pesquisadora, também levou a esse entendimento:

\footnotetext{
Pesquisadora: Não sabia que você estava trabalhando aqui.

Professora: Graças a Deus consegui. E você? Vai vir trabalhar aqui quando acabar a pesquisa?

Pesquisadora: Estou querendo, mas é muito contramão para vir da minha casa.

Professora: Pense bem, a gente sempre desejou uma escola que pudesse desenvolver um bom trabalho, onde tenham muitos professores para discutir sobre educação de surdos. Escola igual a essa pra quem é da nossa área não existe.
}

A fala da professora, expressa para além do sonho de uma escola para surdos, o desejo dos profissionais de ter um espaço para discutir e desenvolver os conhecimentos, onde houvesse a troca dialógica que favoreça o aprendizado e um espaço para criar estratégias para melhor atender os estudantes surdos da rede pública. 
No entanto, esse autorreconhecimento, muitas vezes, transborda para uma consideração de superioridade em relação a outros profissionais das demais escolas. Consideram que, apenas por estarem lotados na "escola dos sonhos", ou seja, o fato de terem sido remanejados para lá, quando da criação da escola, já seria uma prova de sua excelência.

Assim, o coletivo social da escola não deixa de ter conflitos internos e pontos de tensão entre seus idealizadores. Dentre eles, pontos de reivindicação para a melhoria da escola, como, por exemplo, a unânime compreensão da necessidade de atualização da estrutura física.

Outra questão que pode suscitar debates está relacionada às considerações sobre estratégias de ensino baseadas exclusivamente no uso permanente de Libras, já que a língua de sinais ocupa um espaço significativo no modo como esses professores configuram a prática pedagógica e que pode estar excluindo objetivos relacionados à continuidade dos estudos, tal como ansiava a aluna que se transferiu da EB.

Talvez porque as questões linguísticas que motivaram a criação da escola sejam significativamente fortes para enfraquecer aspectos também significativos que a escola deve enfrentar e que estão para além do fator linguístico que caracteriza a escola bilíngue.

\subsection{Escola Bilíngue: espaço privilegiado para desenvolvimento de linguagem}

As práticas e convivências na EB decorrem de sua representação como espaço favorável ao desenvolvimento da linguagem. Os professores perguntam sinais em Libras para os colegas ou procuram saber em que contexto pode ser utilizado esse ou aquele sinal. São oferecidos cursos de Libras gratuitamente aos familiares de surdos e aos pais de crianças ouvintes que estudam na escola. Durante o período da pesquisa, foram ofertados cursos pela Federação Nacional de Educação e Integração dos Surdos (FENEIS) e por uma professora ouvinte - cursos de Libras para familiares de surdos e comunidade em geral. Além dos cursos mencionados, professores e funcionários discorrem sobre cursos de formação e trocam conhecimento a respeito de termos e vocabulário.

Em conversa, no pátio da escola, com alguns pais de crianças ouvintes, foi observado que o aprendizado de Libras contribui para a empregabilidade, inclusive na própria instituição como participante do Programa Educador Social Voluntário ${ }^{12}$.

\footnotetext{
${ }^{12}$ O Programa do Educador Social Voluntário foi implementado desde 2015 pela política pública educacional do DF com o objetivo é dar suporte às unidades de ensino que desenvolvem educação em tempo integral, educação básica e nos Centros de Ensino Especial. Ver em http://www.consed.org.br/central-de-conteudos/sedf-lancaprograma-educador-social-voluntario-2015
} 
Os relatos das situações que se seguem procuram evidenciar o valor que o desenvolvimento da linguagem e o aprendizado de Libras têm para essa comunidade e que contribui para a significação que essa representação assume nas práticas cotidianas da EB:

a) Uma professora entrou na sala dos professores e perguntou para a coordenadora qual era o sinal para o termo "tempo" (referência a clima, período de duração e tempo). A coordenadora informou e alertou para a necessidade de contextualização;

b) Em determinada ocasião, duas professoras, no pátio, avaliavam os cursos de Libras ofertados por duas instituições no DF. Além de diversas ponderações comparativas, as professoras relatavam as dificuldades para participar dos cursos aos sábados. Em outro momento, quatro auxiliares da educação falavam sobre cursos de Libras. Um deles afirmava que os valores gastos nos cursos têm retorno garantido, pois voltam em forma de gratificação e comentava que os cursos são um investimento. Esse mesmo auxiliar alegava desejar conversar exclusivamente em Libras na escola;

c) Constantemente, estudantes solicitam orientação quanto ao uso de vocábulos na língua portuguesa e na língua de sinais. Durante o intervalo, uma estudante solicitou oralmente o sinal de "acusar" e pediu que a pesquisadora digitalizasse. Após a digitalização, a estudante registrou em caderno de anotação e, em seguida, perguntou em que contexto utilizar a expressão;

d) Em outra oportunidade, a mesma estudante perguntou sobre um termo em língua portuguesa, todavia queria conhecer o vocábulo em língua de sinais. A aquisição de uma língua provoca o aprendizado de outra de modo recíproco (SILVA, 2010).

$\mathrm{Na}$ ocasião, a pesquisadora questionou a estudante:

Pesquisadora: [VOCÊ É CURIOSA, SEMPRE PERGUNTA SINAL, PALAVRA, SINAL].

Aluna surda responde: [PRECISO APROVEITAR, JÁ PERDE MUITO TEMPO. AQUI PROFESSOR SABE SINAL, PROFESSOR QUER ENSINAR].

Essa e outros estudantes possuem bloquinhos de notas, como se fosse um pequeno dicionário, para o registro de palavras em língua portuguesa. Outros fazem semelhante registro no aparelho celular.

Alguns professores provocam os alunos a refletirem constantemente, interrogando-os a respeito de conceitos e termos, tanto em Libras quanto em língua portuguesa. Como exemplo dessa forma de encorajamento, temos o discurso de uma professora, que chamaremos aqui de professora A, que, ao explicar o conteúdo aos estudantes, questionou os alunos sobre um sinal em Libras. Como não houve resposta, ela retrucou: 
Professora A: [VOCÊS ACHAM QUE VOU DAR UM SINAL DE GRAÇA? PESQUISEM E ME FALEM NA PRÓXIMA AULA] (dizendo isso, anotou em seu caderno o termo que questionou para cobrar na aula seguinte. Em seguida, continuou a explicação. Ao final da aula lembrou todos os termos que ficaram para serem pesquisados em Libras e em língua portuguesa).

Em outro momento, em diálogo no horário de almoço, a pesquisadora falou da importância de os estudantes estarem implicados com os processos de aprendizagem para que ocorresse a aprendizagem da língua portuguesa. A professora A, do exemplo acima, respondeu que os professores podem estimular os estudantes. E explicou que há intencionalidade em suas provocações em sala de aula que visam o desenvolvimento dos alunos.

Dessa forma, na EB, tanto a busca pelo aprendizado das línguas, quanto as ações que incentivam o seu uso estão em constante discussão. O interesse pela língua de sinais e pela língua escrita evidencia-se como um princípio amplamente personalizado pela comunidade escolar do qual decorrem práticas pedagógicas e convivenciais nos diferentes contextos da vida escolar.

E assim, tanto o valor que os usos linguísticos têm para os objetivos da escola, bem como o valor sobre os sistemas complexos de comunicação e significação humanos fazem parte da representação que a comunidade da escola tem sobre suas formas de agir em qualquer das funções que estejam desempenhando no momento.

As ações individuais em busca da compreensão de vocábulo, sua contextualização, o empenho por fazer cursos, mesmo fora do horário de trabalho, revelam e expressam formas individuais de significar a proposta da escola.

\subsection{Escola Bilíngue: espaço de acolhimento da diversidade da surdez}

Em documentos legais, a EB afirma abrir-se ao atendimento de surdos e deficientes auditivos- DA, contemplando a situação de cada estudante, ou seja, afirma-se como espaço de acolhimento. "A matrícula na Escola Bilíngue está aberta, prioritariamente, aos estudantes surdos, deficientes auditivos e filhos de pais surdos, que têm a Libras como primeira língua" (PPP, 2014).

Esse princípio está exposto no PPP da instituição, de 2014, e consolidou-se pela observação das ações e relações com os profissionais da escola, como também, revelou-se na fala dos professores. Em certa ocasião, a pesquisadora estava na sala dos professores conversando com uma professora que explicou como se dava a formação de turma no componente curricular Língua Portuguesa: 
Professora: Aqui não dá para atender o português por série, cada aluno está em um nível na língua portuguesa. Com os meus alunos, eu trabalho conteúdo mais básico. Tenho dois que são matriculados comigo e são atendidos pelas meninas de atividades. Já os alunos da professora A (refere-se a outra professora de língua portuguesa) trabalham conteúdos preparatórios para o vestibular.

A Pesquisadora provoca: Deve ser complicado montar o horário para coincidir (olha para a coordenadora que está na mesma mesa).

Coordenadora: Dá um trabalhinho e ainda temos que conseguir ajustar com as meninas de atividades que participam dos atendimentos. Nós temos alunos de todo tipo. Não adianta colocar tudo junto conforme a série.

Considero que a fala da professora e da coordenadora, que aceita o desafio de montar horário para privilegiar as diferenças de aprendizado da língua, remete ao fato de que ambas acolhem as diferenças. A coordenadora é enfática ao dizer que "temos todo tipo de aluno". Afinal na EB, dentre os 139 estudantes surdos, 13 são implantados e vários oralizados. Fica difícil precisar o número de estudantes oralizados, pois seria necessário avaliar os vários níveis de oralização, o que não é interesse no momento. Esses alunos, nos intervalos e horário livres conversam oralmente com os professores e funcionários e quando se dirigem a outro surdo, falam em LS.

Nos discursos de militantes sinalizadores, mesmo as pessoa que se intitulam como deficientes auditivos devem ser chamados de surdos. Nesse discurso da combatividade, o fato de alguém identificar-se como deficiente auditivo é não aceitar a própria condição, representa a busca da normalização, é registrar-se pela ausência (PERLIN, 2014). Assim, a declaração do PPP ao salientar que o público alvo é formado por "estudantes surdos, deficientes auditivos e filhos de pais surdos" indica uma perspectiva de acolhimento à diversidade, já que o conjunto das expressões do PPP da escola remetem à abertura a todos os grupos de estudantes surdos.

O princípio registrado no PPP aparece também como elemento de diversas falas dos professores da escola indicando que o acolhimento à diversidade não é apenas um discurso escrito, mas um discurso que se articula às ações e produções dos professores e que ganha valor nos diferentes espaços vivenciados.

O seguinte episódio corrobora essa orientação à diversidade que, neste contexto específico, preside o planejamento pedagógico para um estudante surdo cuja aquisição de linguagem ocorreu tardiamente, pois só aos 14 anos teve seu contato com LS. Atualmente, tem 33 anos e está no $1^{\circ}$ ano do ensino médio. Em uma disciplina, o professor se dirigia a ele com mais frequência. Na ocasião, Juliano copiava e participa ativamente de tudo. O professor ia às mesas e perguntava, observava o olhar de cada aluno e explicava, às vezes para um único aluno, 
conforme a percepção se houvera ou não o entendimento do que pretendia. O trecho a seguir ilustra a construção:

Pesquisadora questiona: Na sua disciplina, Juliano consegue acompanhar, né? Professor: Ele consegue, mas tem que ficar o tempo todo na cola dele, senão perde o fio da meada e depois eu não acho. Sento ele perto de mim e vou puxando a orelha.

Esse professor está atento ao modo peculiar de aprendizagem dos estudantes, criando estratégias para alcançar Juliano. Percebe-se, assim, a preocupação dos professores com processos individuais desse e de outros estudantes. Nesse caso, observa-se que o professor, em sua ação pedagógica, também expressa a preocupação em transformar a escola em espaço de acolhimento da diversidade, quando fica "o tempo todo na cola dele" em razão do modo singular de aprendizagem desse estudante, caracterizado pela aquisição tardia de Libras.

Um dia na sala dos professores, ocorreu o seguinte diálogo entre a coordenadora e uma das professoras surdas a respeito do mesmo aluno:

Prof. Surda: [PRECISAMOS MONTAR ALGUM PROJETO DE PORTUGUÊS A NOITE].

A coordenadora questionou: [PARA OS ALUNOS DA NOITE?] Professora surda: [ELES JÁ TEM, ESTOU FALANDO DE MAIS OUTRO. DOMINGO, JULIANO ME PROCUROU NO SKYPE. DIZ QUE NÃO AGUENTA MAIS SER BURRO E QUE QUER APRENDER PORTUGUÊS. CHOROU MUITO].

Coordenadora: [VOCÊ ACHA QUE DÁ PARA ENCAIXAR MAIS UM PROJETO NA GRADE DA PROFESSORA FRANCISCA? (se referindo à professora de português do noturno) VAI FICAR PESADO].

Professora surda: [VAMOS DAR UM JEITO] (em seguida se vira para mim tentando justificar) [DÁ DÓ DE VER O SURDO SOFRENDO. ELE APRENDEU LIBRAS TARDE. TEM MUITA DIFICULDADE DE APRENDER PORTUGUÊS. PRECISAMOS AJUDAR].

Os professores e professoras procuram flexibilizar o planejamento das atividades e atendimentos ofertados de acordo com as necessidades dos alunos, isso, porém não é consenso, já que nem todos os professores que ali atuam compreendem o estudante em sua potencialidade.

Outra situação, que também indica para o princípio do atendimento à diversidade, corresponde a um estudante oralizado que parece ter comprometimento cognitivo. Ele fala muito de carros, sabe seus preços e marcas e afirma que vai comprar esse ou aquele outro veículo. Certa vez, observou-se um professor conversando com ele e questionando sobre um determinado modelo de carro. O professor se dizia interessado em adquirir um determinado modelo de carro e que precisava de maiores informações. Quando acabaram a conversa, a pesquisadora questionou: 
Pesquisadora: O que ele fala é correto? Eu não entendo nada de carro e não sei. Professor: Sim, ele entende mesmo. Uma professora aqui (fala o nome da professora), queria comprar um carro e pediu que ele pesquisasse os pontos positivos e negativos do carro. Ele chegou com tudo certinho.

Pesquisadora: Achei que ele não sabia ler.

Professor: Ele sabe algumas palavras, mas ninguém sabe como. Para pesquisar sobre carro ele consegue. Já tentamos fazer ele escrever sobre o assunto, mas não saiu nada. Ele pesquisa e sabe falar. Mistérios da EB (e sorri).

A expressão do professor manifesta que os professores estão atentos ao percurso histórico e aos interesses dos estudantes. Porém nem sempre conseguem transformar essas iniciativas em estratégias pedagógicas efetivas. Tais iniciativas, no entanto, parecem se constituir em um primeiro passo na construção dessas estratégias porque colaboram com o conhecimento sobre o aluno e suas especificidades de aprendizagem e desenvolvimento, e potencialmente permitem a emergência de novos sentidos sobre a pessoa surda e a aprendizagem.

Uma aparente contradição foi identificada em relação a essa enorme diversidade de quadros que os estudantes da EB apresentam. Há contradição entre a forte concepção de uma escola de surdos, cuja língua de instrução é LS, em relação ao discurso de que os estudantes oralizados ou com implante coclear alcançam melhores resultados acadêmicos na EB. Em uma ocasião, no horário de almoço, a pesquisadora conversava livremente com estudantes no pátio e com uma professora surda. O assunto girava em torno de alvejante para roupa. A professora surda digitalizou: [Q-B-O-A]. Uma estudante falou que o nome correto é [ÁGUA S-A-N-I-TÁ-R-I-A]. A pesquisadora elogiou o conhecimento da estudante, ao que a professora surda respondeu: [ELA SABE MUITO PORTUGUÊS, PRECISA VER O TEXTO. PORQUE É IMPLANTADA] e olhou com ar de estar em posição de inferioridade em relação à estudante. Imediatamente, a pesquisadora questionou se apenas os surdos implantados são conhecedores da língua portuguesa e fazem melhor uso dela na escrita. Os alunos se dividiram, alguns disseram que sim "surdo implantado sabe mais", outros afirmaram que talvez o estudante implantado saiba mais vocabulário. A professora surda se inquietou com a provocação, não queria admitir o que afirmara, ela desconversou e o tema voltou para assuntos do cotidiano.

A professora surda foi pega nessa aparente contradição entre sua condição de pertencimento à liderança surda em que deve ideologicamente se opor à valorização de surdos implantados, e o reconhecimento expresso em sua fala sobre a significação do implante para o conhecimento do Português escrito.

A professora surda, proveniente de uma educação historicamente marcada pela valorização dos Surdos oralizados, em detrimento dos Surdos sinalizadores, reforça esse padrão 
social na sua fala (AFONSO, 2007), entretanto, percebe que contradiz as bandeiras que defende e por isso desconversa, mudando de assunto. Uma aparente contradição que, subjetivamente, naquele momento prefere não enfrentar.

A dicotomia entre modelos de educação embasados na oralização ou em LS presentes na educação de surdos como um todo, também se revelam na escola, pois as representações acerca da pessoa surda manifestam-se também na escola como elementos que participam e nutrem as significações que o grupo tem sobre aspectos da educação de pessoas surdas.

Em outra situação, quando uma mãe manifesta o interesse em fazer o implante coclear, uma professora surda, que não é a mesma do exemplo acima citado, manifesta:

Professora surda: [NÃO VOU FALAR MINHA OPINIÃO. SE FOSSE MEU FILHO EU NÃO FARIA. VOCÊ QUEM SABE, SE O FILHO MORRER, EU AVISEI].

Ao mesmo tempo em que termina sua fala, a professora surda sai com os olhos lacrimejantes, como se a decisão do implante coclear fosse assunto incomodo e de forte apelo emocional para essa professora.

A emocionalidade emergente na fala da professora surda ao falar do implante coclear pode ser decorrente de sua impossibilidade em fazer com que os responsáveis desistam da intervenção cirúrgica.

Para a comunidade surda esse assunto se apresenta como conflituoso e tenso, talvez em decorrência de situações de colegas surdos e estudantes que não alcançam sucesso em suas intervenções cirúrgicas ou mesmo que apresentam sequelas após a cirurgia. Pode também ser pensado a partir das discussões na comunidade surda sobre a importância da manutenção das características da pessoa surda que de alguma forma se articula com a ideia de que surdos formam uma única comunidade, com um cordão umbilical, o Deaf Hood, postulado por Paddy Ladd (1993), que os une e pelo qual devem se unir para se "proteger" das práticas ouvintistas, ou seja, das práticas clínico-terapêuticas que buscam "normalizar os surdos". Mesmo sem ser muito ativa nos movimentos políticos surdos, essa professora parece significar o implante coclear como uma ameaça à integridade física e intelectual do surdo.

Sob essa mesma ótica, diferenciada situação ocorreu quando outra professora mencionou, na sala dos professores, a sua preferência em atuar com estudantes de ensino médio por preferir a faixa-etária de estudantes acima de quinze anos. Assim, ao iniciar seus trabalhos com estudantes surdos, optou por trabalhar com alunos dos anos finais do ensino fundamental, pois já havia percebido ao longo de sua vida profissional, que, por conta das múltiplas repetências nas fases iniciais da aprendizagem formal, quando estes estudantes chegavam aos 
anos finais do ensino fundamental, já estavam na faixa etária de estudantes que ela assumia ter preferência. Como a distorção idade-série é minimizada na EB, nesse contexto a professora tinha que trabalhar com crianças menores e por isso reclamava. Naquele momento, a pesquisadora questionou sobre se a não distorção idade-série seria um ponto positivo em relação à educação na EB e aí, como não houve consenso entre os professores, dois discordaram, em voz baixa, enquanto os outros concordaram, a questão se tornou polêmica. Para evitar o embate anunciado pela discordância, logo outra profissional trocou de assunto, falando sobre o lanche diferente que trouxera e todos se calaram.

Percebe-se que quando se trata de assuntos conflituosos, como no caso da reação da professora à notícia sobre o implante coclear ou no caso acima, evitam-se as discussões sobre os posicionamentos. Considero que a falta de discussões sobre pontos de tensão possa vir a paralisar o grupo de profissionais e ser desfavorável ao desenvolvimento do grupo, pois ouvir a opinião e a argumentação do outro pode levar à reflexão de cada um dos atores sociais e, em decorrência, a processos de aprendizagem e desenvolvimento do grupo. Por outro lado, não se pode descartar que a presença da pesquisadora possa ter inibido as discussões do grupo.

\subsection{Escola Bilíngue no contexto da educação do Distrito Federal}

Afonso (2007), afirma que a implantação de políticas públicas de saúde provocou o decréscimo no quantitativo de pessoas surdas na população e consequentemente um dos motivos da redução de estudantes surdos nas escolas. Os programas de prevenção à meningite, ao sarampo, à caxumba e à rubéola apontadas por Rinaldi (1997) como principais causas da surdez têm reduzido a ocorrência dessas doenças e, consequentemente, o número de crianças que ingressaram na escola com surdez.

Conforme Ministério da Educação MEC (2015) no ano de 2003 haviam 95.505 estudantes Surdos matriculados na educação básica em todo o território nacional, este número foi reduzido para 66.617 em 2014 (BRASIL, 2015). A redução de estudantes Surdos no sistema educacional justifica a necessidade de discutir-se um novo formato de educação desses estudantes e outras ações no âmbito da SEDF.

Outro fato importante, é que, na SEDF, os professores que atuam diretamente com estudantes Surdos ou pessoas com deficiência recebem a Gratificação de Atividade de Ensino Especial -GAEE prevista por Lei 4075/07 e reiterada pela Lei 5.105, 03 de maio de 2013 (DISTRITO FEDERAL, 2013). A gratificação corresponde a $15 \%$ do valor do vencimento básico do padrão I da etapa em que o professor estiver posicionado. 
Como já dito a EB foi inaugurada em 2013, e, assim, de modo geral, os professores da SEDF que atuam com estudantes surdos relacionam a EB com o decréscimo de alunos surdos e decorrente diminuição da possibilidade de recebimento da GAEE. Dessa forma, a EB passa a ser significada como uma ameaça para a diversidade do atendimento de surdos nas diferentes regiões administrativas do Distrito Federal.

Os professores habituados a trabalhar com estudantes surdos nem sempre compreendem que a redução do número de estudantes ocorreu em todos os espaços escolares e, assim, atribuem à diminuição do número de alunos matriculados à migração para a EB. A situação se torna mais complexa porque, de fato, alguns estudantes e seus familiares estão buscando a EB e transferindo-se de outras Regiões Administrativas do Distrito Federal, o que pode reduzir, ainda mais, o número de alunos surdos nas escolas comuns.

Adicionalmente, as ações dos órgãos centrais da SEDF que buscam o fechamento de turmas devido ao quantitativo de estudantes passam a ser, no discurso dos professores, compreendidas como ações para empoderar a EB. Dessa forma é recorrente ouvir dos professores das escolas do DF que a EB é a "escola que rouba aluno da gente".

O discurso dos profissionais que identificam a diminuição dos alunos surdos gera disputas por espaço em que uma escola procura depreciar a atuação da outra e passa a ser uma forma de impedir que familiares e estudantes possam ter clareza sobre qual modelo de educação optar. Essa polêmica gera uma nova separação na sempre dicotômica educação de surdos que tem como desdobramento maior o assujeitamento das famílias e dos próprios estudantes surdos a decisões e posicionamentos de profissionais especialistas como vem ocorrendo ao longo da história de educação de surdos.

São esses profissionais da área médica e educacional que acabam por decidir pelo melhor modelo educacional e linguístico e os pais, muitas vezes impactados com o diagnóstico ou em situação de ligação afetiva construída com esses profissionais, deixam a cargo deles a opção pelo que é melhor no processo de escolarização de seus filhos.

As pesquisas de Emerton, 1998; Gomes, Coelho \& Cabral, 2006; Dorziat, 2009; Gomes, 2010; Gomes, 2012; Skliar, 2003, 2012 e Rocha, 2015 chamam atenção para discursos e ações atuais, embasados no mesmo ideal da educação do século XVII, que se caracteriza por um modelo hegemônico na educação de surdos. A polêmica em relação à EB, parece repetir ou, uma vez mais reeditar, a controvérsia sobre a forma universal ideal de um modelo de educação para Surdos.

Soma-se a esta questão, o reconhecimento que as línguas de sinais passaram a ter e que é ressaltado por Rocha (2015). A autora atribui esse alcance ao acesso tecnológico: 


\begin{abstract}
As línguas de sinais vivem uma expansão sem precedentes em sua história. A revolução que Gutenberg operou para as línguas orais, a tecnologia, hoje, opera para as línguas de sinais. Os meios tecnológicos vêm viabilizando seu registro, sua difusão, seu alcance para potenciais falantes, seu estudo e suas impregnações. Deixou a prisão de uma folha de papel, onde suas possibilidades pouco cabiam e ganhou espaço tridimensional onde verdadeiramente se realiza. As línguas caminham por múltiplos itinerários, onde expostas a toda sorte de imbricações cumprem seu fado de realizar a comunicação humana (ROCHA, 2015).
\end{abstract}

Rocha (2015) manifesta, ainda, preocupação sobre esse avanço se não vier acompanhado de reflexão e de abertura às trocas. Uma vez que, no campo científico, as línguas de sinais são recentes e carecem de investigações e construções sobre seu uso e desenvolvimento.

Enquanto as discussões sobre os processos de comunicação das pessoas surdas estiverem pautadas na supremacia da uma língua oral ou de uma língua sinalizada perde-se o foco principal e retorna-se a um modelo redutor na compreensão sobre o sujeito surdo e seus processos de desenvolvimento.

\title{
4.5. Escola Bilíngue, um final para trama
}

As crianças surdas matriculadas na escola bilíngue, onde a língua de instrução é a Libras, passam a vivenciar cotidianamente um sistema educacional que organiza e põe em atividade um conjunto de valores culturais, crenças e representações que orientam significados e sentidos sobre a aprendizagem e desenvolvimento de pessoas surdas e da própria surdez.

É esse conjunto de valores que, de alguma forma, permite a compreensão de que a escola não está simplesmente buscando reproduzir o mito de Babel, tão criticado por Larrosa \& Skliar (2011). Em sua crítica os autores indicam a impossibilidade da existência de uma cidade com uma língua única, onde por não haver respeito ao código divino seus moradores passam a ter que aprender a conviver com a falta da construção da compreensão mútua, decorrente da diversidade linguística, como correspondente à diversidade humana.

Por ser a única escola nesse modelo, na EB do Distrito Federal são matriculados Surdos de diversas Regiões Administrativas do DF. Assim, embora a EB pareça ser uma Babel que propõe uma única forma homogênea de comunicação, via língua de sinais isso é apenas sua face mais aparente. Na sua dinâmica cotidiana, transparecem valores que respondem às singularidades de cada criança e jovens surdos lá matriculados, a partir de suas histórias de vida, situação econômica, diversidade de composições familiares e diferentes situações socioculturais. Dessa forma, cada estudante da escola tem a possibilidade de participar da 
constituição social desse contexto escolar de modo singular. No próximo eixo, lanço meu olhar sobre essa singularidade, procurando compreender aspectos da subjetividade individual dos sujeitos colaboradores dessa pesquisa.

\section{OS ESTUDOS DE CASO BERTHIER E VANESSA}

\subsection{Caso Berthier}

A família de Berthier é composta por pai, mãe e um irmão. A diferença de idade entre os irmãos é de aproximadamente oito anos. Quando o primeiro filho nasceu surdo, a família foi aconselhada a não ter outros filhos, por suspeitar-se de problema congênito e a mãe esperou alguns anos. Assim que Berthier nasceu, o diagnóstico foi realizado em passo acelerado para confirmar a suspeita de surdez congênita. Desse modo, o irmão mais velho que já era conhecedor de LS passou a estabelecer a interação com Berthier.

A mãe, porém, obedecia às orientações da escola oralista em que os filhos recebiam atendimento desde o diagnóstico, quanto à não estimulação do uso da língua de sinais. Mesmo assim, ela se culpa pelo fato de seus filhos não terem desenvolvido a língua oral, apesar de todo o esforço que empregou para isto. Culpa-se também, pelo fato dos filhos optarem pelo uso da LS. "Eu fiz de tudo para meus filhos falassem, quem olha pensa que eu não me esforcei, fiz de tudo, mas eles não quiseram falar, preferiram Libras, eu tenho que aceitar". A mãe de Berthier trabalha em uma escola reconhecida por atender alunos surdos, ainda assim, não é fluente em libras, sabe alguns sinais básicos com os quais se comunica com os filhos.

Para a mãe, a avaliação da sociedade pelo seu esforço parece se dar pelo grau de aprendizagem de língua oral de seus filhos surdos. Em sua pesquisa, Orsoni (2007) aponta para o impacto da surdez sobre as mães que, por vezes, necessitam abandonar o emprego para acompanhar os filhos surdos nos mais diversos atendimentos (sessões de fonoaudiologia, ensino de português como segunda língua, sala de recursos, etc). Ainda assim, podem desenvolver processo de culpabilização que paralisa também seus filhos surdos por produzirem sentidos e significados, que unidos a outros sentidos, se configuram como incompetência diante da situação de, por exemplo, não aprendizagem da língua oral.

Quanto ao pai, segundo relato da mãe, ele é muito rígido e pouco conversa com os filhos. Há enfrentamentos de Berthier e do pai, pois este não aceita as reclamações daquele quando bebe e chega nervoso em casa. Conforme relato da mãe, a relação de Berthier com o pai é conflituosa e intermediada por ela. 
Quanto ao irmão de Berthier, esse constituiu família com uma jovem surda e durante alguns anos viveu com ela na casa dos pais. Atualmente, o casal se separou e compartilha a guarda de uma filha de aproximadamente três anos. Deste modo, a sobrinha passa um tempo significativo nesse núcleo familiar.

A família de Berthier participa de festas e passeios em conjunto e as postagens dele, nas redes sociais, mostram viagens, passeios a chácaras e almoços em família. Além disso, Berthier participa das festas nas casas dos amigos.

Berthier e a pesquisadora já se conheciam de outra situação escolar, antes mesmo do convite para participar da pesquisa. Desde o início, Berthier se mostrou aberto a participar da investigação. Participava ativamente dos encontros agendados para a pesquisa e mantinha diálogos livres e nas redes sociais com a pesquisadora.

Compreendendo o contexto histórico de Berthier, serão apresentadas as construções da pesquisadora sobre sua história e, posteriormente, serão entrelaçadas à subjetividade social da escola e a de Vanessa.

\subsubsection{Comunicação}

A aquisição de linguagem, por Berthier, foi marcada pela impossibilidade de desenvolvimento da língua oral que a mãe desejava que seus filhos aprendessem e o convívio com a língua de sinais que ele aprendeu naturalmente na interação com seu irmão. Conforme expressão da mãe em conversa informal, após utilização do instrumento complemento de frases:

Mãe de Berthier: Era o que eu mais queria, fiz de tudo para que eles falassem, porque meu maior medo era porque o mundo é dos ouvintes. Hoje eles falam muito pouco, mais palavras soltas, mas é o suficiente para eu entender e eles me entenderem.

Sentidos subjetivos produzidos nas experiências dos processos comunicativos participam da subjetividade individual, bem como constituem as vias de comunicação com o outro.

Com o intuito de conhecer como os sujeitos de pesquisa enfrentavam situações de conflito e como conseguiam se comunicar, foi proposta a apresentação de um vídeo. Após a discussão, os alunos expressaram por meio de desenho situações vividas em que não foram compreendidos e como tinham se sentido. Berthier produziu o seguinte desenho: 


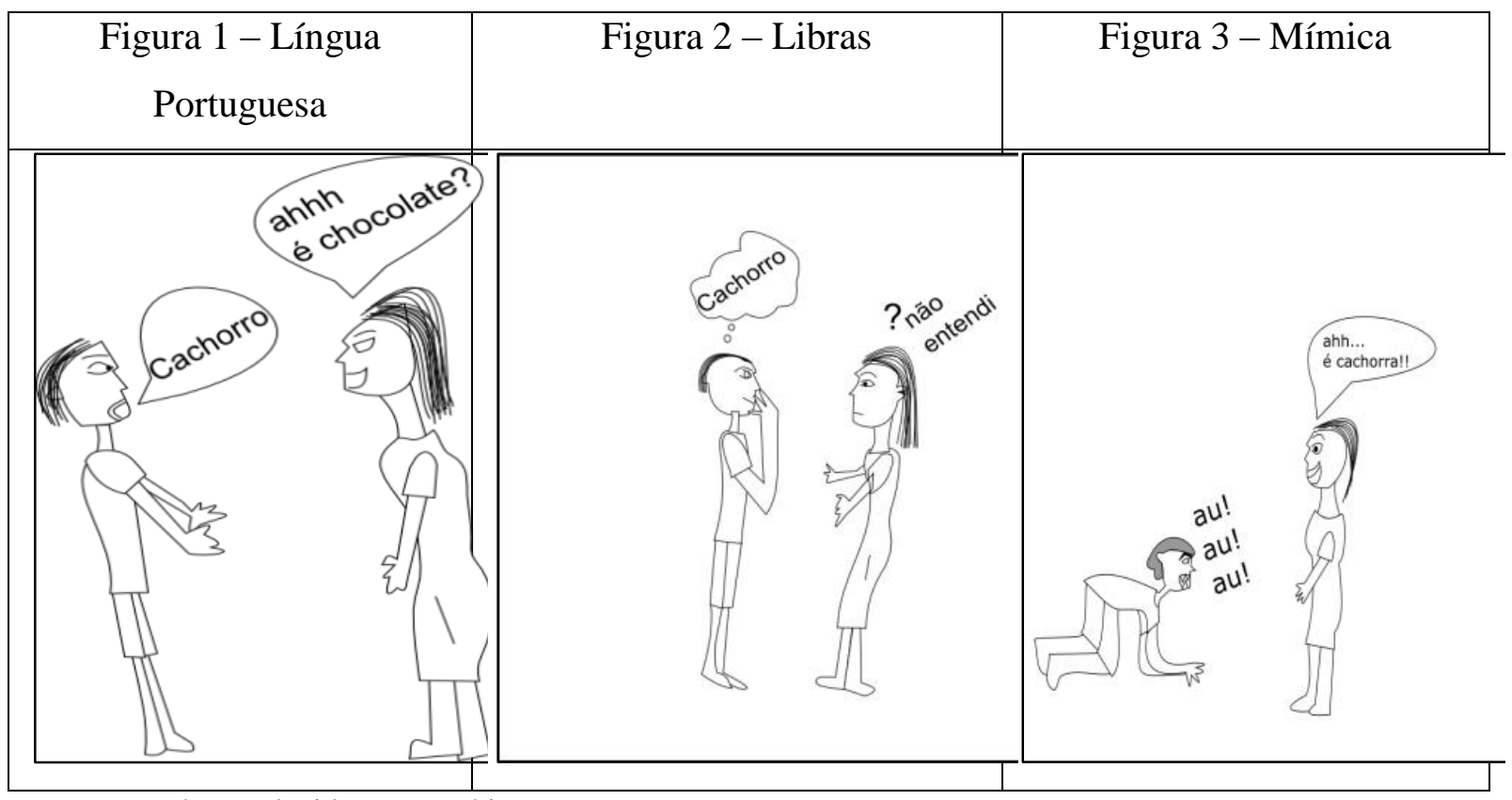

Fonte: Desenho produzido por Berthier

Na figura 1, ele usa a língua de sua interlocutora, português. É possível que a sua oralização precária não seja compreensível, na figura 2, por não ser compreendido, Berthier faz uma mudança de código e fala em língua de sinais: "cachorro". Permanecendo a dificuldade de compreensão, Berthier faz a mímica do cachorro, conforme a figura 3 , enquanto seu interlocutor (sorrindo) compreende. Observa-se esforço e variação de sistemas de comunicação por parte de Berthier e, também, é possível perceber, pelo desenho, os constrangimentos vividos em situações de tensão na comunicação.

Assim, parece que a questão não se reduz ao código utilizado, mas a relação que se estabelece no processo comunicativo e a leitura que Berthier faz do envolvimento de seu interlocutor com ele e com o contexto.

O conteúdo desse desenho acompanhado do processo dialógico em que foi apresentado levou a pesquisadora à construção do indicador de que Berthier, em situação de tensão na comunicação com o ouvinte, optava pelo isolamento. Utilizando outro instrumento de pesquisa, a dramatização, manteve-se esse indicador, porque ao dramatizar situações do cotidiano, Berthier permanecia calado sem interagir com os interlocutores ouvintes.

Já na composição escrita sobre como gostaria de se comunicar, Berthier apresentou o seguinte trecho escrito, a partir da provocação da pesquisadora: [COMO VOCÊ DESEJARIA QUE FOSSEM AS SITUAÇÕES DE CONVERSA?]:

Berthier (em trecho escrito): Eu quero que todo mundo use LIBRAS e fale. Eu queria obrigar, mas não posso fazer nada, porque cada um tem seus direitos. Porque as 
pessoas falam e ficam rindo, eu penso que elas estão falando e rindo de mim. Eu fico assustado na rua, com os vizinhos, no ônibus, na escola e com professores, é muito ruim. O surdo fica só! O surdo fica sem saber o que está acontecendo, inocente! (Grifo nosso).

A expressão de Berthier deixa entrever que a comunicação coletiva oralizada mostra-se tensa para ele porque não sabe o que "as pessoas estão falando" e porque "ficam rindo". Nesse contexto, Berthier prefere "fica só", uma vez que acha que estão "falando e rindo de mim". Essa revelação levou a pesquisadora a manter o indicador inicial de que Berthier evita comunicação no meio ouvinte. Neste caso, o silenciar-se é a opção.

Entretanto, de modo contraditório, quando utilizado o instrumento de escolha de gravuras, ao optar por gravura que representasse seus amigos, Berthier escolheu a figura 4, afirmando que alguns amigos gostavam de aprender Libras e ele, de ensinar (com olhar orgulhoso). Observa-se, aqui, que não é sempre que Berthier opta por não se expressar, pois há situações em que seus interlocutores se interessam em compartilhar a língua de sinais com ele. Esses estão no grupo de seus amigos.

Figura 4 - Gravura indica por Berthier

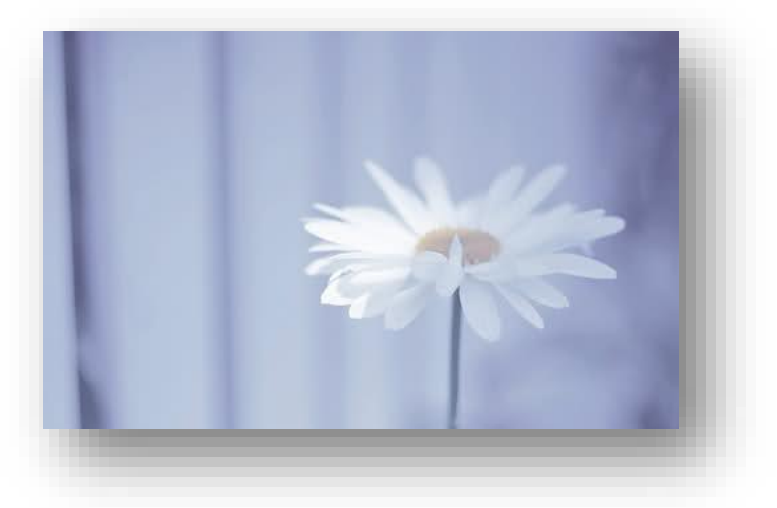

Fonte: Gravura indicada por Berthier para representar amigos ouvintes

Em outra ocasião, em que nossa comunicação foi mediada pelo WhatsApp, ao ser questionado como havia sido a prova do PAS - Programa de Avaliação Seriada ${ }^{13}$, Berthier enviou a seguinte mensagem que já havia sido publicada no Facebook:

Berthier: Hoje em meu dia foi horrível demais!!!! Hoje fui na prova PAS. Uma mulher disse: - Intérprete Libras vai vir aqui pouco mais tarde. Eu disse: OK. Depois eu lia na prova foi difícil demais e eu não conseguindo de entender e eu chamei ela e eu perguntei "Cadê intérprete Libras" para ela disse: - Ah, intérprete libras não vir mais aqui. Eu começando fiquei de bravo, e depois não conseguindo entender na prova

${ }^{13}$ O PAS é uma proposta de avaliação para acesso a graduação da Universidade de Brasília, composta por três avaliações que ocorrem ao final de cada ano do ensino médio. 
e eu pedindo para ela me explicar, mas ela me explicou muito fraco e eu não entendendo o que ela estava falando e também ela escrevendo papel e eu também não entendi e não conhece algumas palavras, como eu vou entender? Que impossível, e ela ficava rindo da minha cara e eu fiquei nervoso, vergonha e aguentei para não chorar, e eu caí na prova. Mas a lei aqui é muito fraco. Afff!!!!!!

Diante de situação de impasse comunicativo, nota-se que Berthier cria estratégias para comunicar-se. Inicialmente, buscou falar com a aplicadora da prova e enquanto aguardava a chegada da intérprete, fez a leitura da prova para responder sozinho. Diante do vocabulário desconhecido, ele novamente procurou a aplicadora e solicitou que ela fizesse a interpretação. O relato nos permite compreender que Berthier é sujeito de seus processos comunicativos, pois cria estratégias para se comunicar mesmo em situação de tensão e conflito.

A troca de mensagens evidencia que, mesmo onde se manifesta a barreira de comunicação, Berthier cria estratégias para minimizar o impasse comunicativo, ainda que não esteja entre amigos que compartilhem do mesmo código linguístico. Na circularidade do processo de pesquisa, podemos perceber que o indicador inicial de que "Berthier opta pelo isolamento" ganhou novo sentido na construção da informação, agregando hipótese de que, quando percebe a intencionalidade dos interlocutores em compartilhar o código, ele sai do silêncio, agora, mesmo em situação de tensão comunicacional, ele cria estratégias e esforça-se para que haja uma comunicação efetiva, revelando-se como sujeito de seus processos de comunicação. Desse modo, começa-se a compreender a complexidade da subjetividade individual de Berthier, que permite:

a produção de posições específicas, singulares, diante dos diferentes espaços da subjetividade social. Isso representa um processo permanente que tomará formas diferentes de acordo com as estruturas de poder e das formas de funcionamento que caracterizam esses espaços sociais (GONZÁLEZ REY, 2012b, p. 145)

Seus interlocutores, nas redes sociais, são surdos e ouvintes que comentam suas postagens e, por vezes, divertem-se com elas ou são convidados a reflexão por elas.

Nas redes sociais, em especial o Facebook, Berthier - por vezes, de modo criativo utiliza de metáforas em sua comunicação. Nem sempre é compreendido por seus interlocutores o que o leva a explicar o que desejava comunicar. Em alguns momentos, mostra-se impaciente com essa dificuldade de compreensão dos seus colegas. Em outras, sugere estratégias para compreensão de textos escritos, que são utilizadas ou criadas por ele mesmo e manifesta-se aberto a colaborar com os interlocutores surdos na compreensão do texto. Usa as redes sociais para manifestar sua indignação com a postura acomodada de alguns surdos: 
Berthier: Aff, Os surdos não compartilham? Nada? Por acusa não sei de ler o português

Mais importante que informar!!! Se alguns pessoas postam no face mais coisa de importante que você não lê e não interessem, e depois vocês vai perdem, e depois vocês reclamam que falta de intérprete ou Libras!! Mas intérprete não tem culpa mesmo!! Porque por acusa vocês não sabem de lê!!! Vocês faltam de coragem pra dizer que eu não entendi, então eu te ajudo e explico, só isso, ou pode mostrar pra qualquer pessoa pra te explica esse texto. Nossa, eu já cansei de vocês!!! Porque os surdos não interessem o próprio futuro!!! (Publicação no Facebook, em 24 de novembro de 2015).

O texto nos mostra que as redes sociais, para Berthier, são espaços para a expressão da sua subjetividade. Nelas, ele faz crítica aos surdos que não compartilham nada e ainda reclamam a falta de intérprete de Libras. Ele aponta o fato de não saberem português como uma possível causa da acomodação dos surdos que esperam apenas do intérprete as informações do cotidiano. Berthier orgulha-se da pessoa que é e compreende-se na condição de ensinar Libras para os ouvintes e português para os surdos: o ensinar dá a ele o status de ser alguém com saber próprio e à frente de seus pares.

Se por um lado Berthier assume sua surdez como possibilidade de ensinar Libras para os ouvintes, por outro, assume características típicas de ouvintes quando se propõe a ensinar português para os surdos.

Retomando o processo de construção da informação que tinha como indicador inicial o silenciamento de Berthier, a hipótese de trabalho foi sendo reconfigurada no espaço relacional da pesquisa, sendo compreendido, num segundo momento, que sua opção pelo silêncio depende da intencionalidade dos interlocutores para, em seguida, compreendê-lo como alguém que cria estratégias diante de tensão comunicacional, e, assim compreender que Berthier subjetiva processos de comunicação como alguém que interage e se constitui da subjetividade social dos grupos de ouvintes e surdos dos quais participa. Vale ressaltar que essas produções interpretativas da pesquisadora não constituem um quadro de linearidade, tampouco de etapas subsequentes na vida de Berthier, mas como construção interpretativa sobre um processo sistêmico, complexo, recursivo, contraditório e singular da subjetividade de Berthier.

\subsubsection{Relacionando-se com o intérprete}

No início dessa investigação, Berthier e Vanessa estudavam em uma escola comum, conforme pontuado anteriormente, e eram acompanhados por intérprete educacional. A pesquisadora, no momento inicial da pesquisa, levantou a hipótese de que para Berthier, a intérprete constituía-se em uma das poucas interlocutoras, talvez a única ouvinte, com quem 
Berthier dialogava sobre seus problemas. Para além da questão profissional e de acesso ao conteúdo, essa posição se revestia de um papel marcante, conforme ilustra o diálogo a seguir:

Pesquisadora - [QUANDO VOCÊ QUER CONVERSAR NO DOMINGO, ESTÁ TRISTE NERVOSO?] (Dando exemplos de situações).

Berthier - (olhar aborrecido) [COISA MINHA PARTICULAR, ORGANIZO ARMÁRIO, FAÇO COISA PARA ESQUECER, WHATSAPP] (dirige olhar para o intérprete que está na outra mesa respondendo complemento de frases).

Ao olhar para a intérprete, compreende-se que ela é a destinatária de suas mensagens no WhatsApp. Esse aspecto foi também observado em diálogo com a intérprete, que elucidou que dialogava com seus alunos sobre assuntos variados, como estratégia de aprendizagem, sobre "suas angústias e dúvidas sobre fatos da vida". A pesquisadora fez uma provocação sobre essa questão, que iria muito além das funções profissionais, a qual a intérprete respondeu: "esta 'é' minha função como profissional”. A intérprete revela, ainda, que mantém conversas, inclusive extra horário de trabalho (TAVARES-SANTOS e MADEIRA-COELHO, 2015a). A pesquisadora observou que nessa relação, havia uma troca dialógica que possibilitou a Berthier expressar-se plenamente.

A mãe de Berthier relatava, na ocasião, a preocupação com a mudança de escola do filho e o consequente afastamento da intérprete, com quem ele tinha construído uma relação afetiva. A mãe parecia legitimar e delegar à intérprete a função de aconselhamento, instrução e suprimento de carências que ela, como mãe, não atendia, já que, o diálogo entre eles não acessava a emocionalidade e as produções simbólico emocionais do filho. Nesse caso, poderia atribuir que essa mãe acomodava-se a situação de delegar a outrem a função que legitimamente pertenceria a ela, face a barreira comunicativa. Porém, podem estar configuradas na ausência de diálogos íntimos entre a mãe e o filho outras configurações. Como afirma Peres (2005) interpretando González Rey, pode-se afirmar que existe uma dependência “entre comunicação, atmosfera psicológica das relações e subjetividades individuais geradas no contexto familiar" (p. 321), que podem estar sendo decisivas para que a expressão subjetiva de Berthier esteja ausente da comunicação entre ele e sua mãe.

Nesse sentido, a hipótese da intérprete como uma das poucas pessoas com quem Berthier conversava sobre os seus problemas foi mantida durante o curso da pesquisa até que surgissem novos elementos da subjetividade, agregando sentidos diferentes. A construção da pesquisadora a respeito desse indicador foi sendo alterada no processo dialógico que se constituiu a pesquisa, como veremos adiante. 
$\mathrm{Na}$ reta final da pesquisa, no encontro em que foi utilizado o instrumento, "Esse sou, essa é minha história", que consistia na filmagem de situações, cenários e personagens da história de vida dos sujeitos. Berthier mesmo em uma escola onde os professores são falantes da libras, reportou-se à falta que sentia da intérprete. Conforme sua fala no excerto abaixo:

Berthier: [VIDA NA ESCOLA, TRÊS PARTES: PÉSSIMO, ENTENDER NADA, MELHOR INTÉRPRETE CHEGA, AGORA TODOS PROFESSORES SABE LIBRAS, FALTA SÓ JOANA AQUI] (refere-se a Joana, a intérprete educacional).

Ainda na escola comum, a presença do intérprete educacional no percurso histórico de Berthier é marcada pela possibilidade de compreensão e acesso aos componentes curriculares e estímulo aos professores quanto à implementação de adequações curriculares, (mesmo que nem sempre eficazes). Para além dos aspectos relativos ao espaço acadêmico, o mais importante da presença da intérprete na vida de Berthier, é o espaço relacional construído por eles (TAVARES-SANTOS e MADEIRA-COELHO, 2015b).

A relação com a intérprete é marcante para Berthier, porém, no ano seguinte, novas relações foram se constituindo. Os sentidos subjetivos produzidos em momentos de interação com essa profissional marcaram significativamente Berthier. No início de 2015, ele sempre se referia a ela, perguntando para a pesquisadora se estivera com a intérprete. Mas, em novembro, a intérprete visitou a EB com o intuito de encontrar os dois estudantes. Na ocasião, ele informou que o último encontro dele com a intérprete havia sido no ano anterior. Compreende-se, que apesar de marcante, a relação de Berthier com a intérprete educacional foi esmaecendo, não apenas no âmbito educacional, mas também na troca de mensagens nas redes sociais, pois Berthier, apesar da relação estreita que estabeleceu com a intérprete, configura-a como uma pessoa ocupada que não teria tempo para continuar mantendo trocas dialógicas, conforme relatou.

A relação entre a intérprete e Berthier era bastante estreita, durante o período em que ele permaneceu na escola comum porque havia um contato diário. Porém, construída de forma independente entre os dois. Berthier parece ter constituído outros espaços para falar de si. A hipótese de que a intérprete era uma das poucas pessoas com quem Berthier dialogava foi sendo transformada, pela percepção da facilidade que Berthier tinha de falar dos próprios processos. Como no caso, em que Berthier fez uma postagem no Facebook, onde homenageava a tia falecida há dois anos. Manifestou sentir falta dela e dos diálogos que mantinham. Depois de algum tempo, a pesquisadora imprimiu a publicação citada e conversaram sobre ela onde 
interpretou-se que ele sentia falta dos compartilhamentos que mantinha com a tia e das vivências dos últimos dois anos que não podia mais compartilhar com ela.

Outra evidência da constituição afetiva-emocional que Berthier construía com a pesquisa, vem do fato de que constituiu-se um contexto para a livre expressão desse colaborador, pois parece ter preenchido o espaço antes ocupado pela intérprete. O diálogo estabelecido entre a pesquisadora e Berthier nos momentos finais da investigação, via WhatsApp, explicita a construção:

Berthier: Amei conhecer você. Vc parece quase igual ela!!! (Referindo-se a intérprete).

Pesquisadora:

Berthier:

Pesquisadora: Ah! Final pesquisa vamos passear?

Berthier: Final????

Pesquisadora: Sim. Acabar pesquisa. Amizade continua.

Berthier: Que infelizmente. Eu adoro sua pesquisa porque é leve.

Para Berthier, a pesquisa configurou-se como espaço para falar de si e de suas produções subjetivas, portanto, participar da investigação fez com que ele se sentisse leve. Uma vez que nesse espaço relacional expressou aspectos da subjetividade e compartilhou situações vividas e significativas.

A hipótese de que a intérprete era a única interlocutora com quem dialogava sobre situações significativas para ele foi sendo reconfigurada pela pesquisadora que compreendeu que Berthier constantemente (re)configurava contextos e relações afetivas em que expressava sua subjetividade e que a pesquisa havia sido um dos contextos em que ele evidenciou isso.

\subsubsection{A família como constituinte de diversas configuracões subjetivas}

Sempre que questionado sobre situações significativas em sua vida, Berthier expressava que a família ocupava lugar de destaque. Conforme expressa em dois trechos do disparador, leitura de um selfie, utilizado como instrumento dessa investigação:

A pesquisadora questionou: [O QUE TE DEIXA FELIZ?]

Berthier: [SOU FELIZ POR SER SURDO, POR VIVER COM MINHA FAMÍLIA. É BOM, POR VIVERMOS JUNTOS NA MESMA CASA. TENHO SÓ UM IRMÃO SURDO. SOU FELIZ COM A PARTE DA FAMÍLIA QUE MORA NO MARANHÃO. HOJE TENHO UMA SOBRINHA DE TRÊS ANOS, DISCUTIU (interrompe a citação ao se referir à sobrinha e volta para o irmão que é pai da menina, 
apontando para o lugar de referência utilizado para representar o irmão ${ }^{14}$ ) VIVE COM A MINHA FAMÍLIA. NO MARANHÃO TENHO PRIMOS].

Pesquisadora provoca: [O QUE VC GOSTA?] (Querendo confirmar as preferências de Berthier.)

Berthier: [GOSTO DE SURDO, FAMÍLIA, AMIGOS, BILÍNGUE].

Pesquisadora: [O QUE TE DEIXA TRISTE?]

Berthier (enumerando): [FIQUEI TRISTE QUANDO MINHA TIA MORREU]. (Se refere à tia, citada anteriormente, no item referente ao intérprete. Expressão de preocupado). [MEU PAI COM CÂNCER, ESTOU TORCENDO, ESPERANÇA QUE DEUS VAI CURAR. MAMÃE FEZ CIRURGIA, AGORA ESTÁ BEM.].

Apesar de Berthier manifestar que a família é importante e motivo de sua felicidade, ele se refere à família como situação problema, quando menciona viajar para o Maranhão para esquecer os problemas e as brigas. Ao ser questionado pela pesquisadora, ele diz que o Maranhão (onde vivem seus familiares) é um local calmo, onde não há brigas.

Em outra ocasião, quando utilizado o instrumento escolha livre de gravuras, que consistia em escolher cinco gravuras significativas em revistas, ele optou pela gravura de um menino vendo filme. Ao ser questionado sobre sua escolha, afirmou que gosta de ver filmes do gênero terror, porque se assustava e depois se acalmava e, assim, esquecia todos os problemas. A pesquisadora questionou quais eram os problemas e ele hesitou em responder. Em seguida, afirmou que os problemas consistem de reclamações para que organize a casa, lave a louça e deixe o celular. Afiançou, ainda, que ao assistir filmes legendados amplia seu vocabulário em língua portuguesa.

Os problemas vividos na família parecem relacionados às exigências feitas pela mãe, para que ele cumpra os afazeres domésticos, que, para Berthier, parecem subjetivados como obrigatoriedade ao horário estipulado pela mãe, o que o incomoda.

Porém, pode expressar outras situações conflituosas como a relação com o irmão mais velho e com o pai, aos quais pouco se refere. Berthier fala das obrigações aos afazeres domésticos para evitar falar das situações de confrontos que o incomodam e que ele não é capaz de modificar. Isso fica explícito quando ele recua responder sobre os reais problemas, que podem ser as situações conflituosas, pois refere-se ao irmão apenas utilizando o espaço sintático em Libras referente ao irmão com o sinal conflito/discussão, conforme trecho acima apresentado. O pai também ocupa posição conflituosa, ou de pouca significação, já que não se

${ }^{14}$ Conforme Stumpf (2005) nas falas em LS o uso do espaço sintático é organizado, como se montasse um cenário, onde organizam-se "objetos e referentes não-presentes" (STUMPF, 2005, p.25). 
refere a ele no decorrer da investigação. O pai teve confirmado o diagnóstico de câncer durante a pesquisa e quando o problema de saúde agravou-se foi citado como alguém grosso, nervoso, porém amado.

As vivências e expressões de Berthier contribuíram para a análise da pesquisadora de que para Berthier a família nuclear é espaço de tensão, de situações conflituosas vividas tanto com o irmão que para ele é configurado como causador de situações conflituosas, apesar de ser o responsável pelas primeiras trocas comunicativas de Berthier. Quanto ao pai, esse parece ausente de produções significativas, pois quase nunca se refere a ele. Em uma ocasião, quando conversávamos sobre problemas, ele se referiu ao pai e fez o sinal de beber e imediatamente mudou de assunto. Até mesmo com a mãe, a quem se refere com carinho, essa também nos parece subjetivada por ele como uma mãe não compreensiva. Assim sendo, as obrigações em relação aos serviços domésticos convertem-se na construção da pesquisa como situações, do contexto familiar, as quais não consegue modificar.

\subsubsection{Sujeito dos próprios processos}

Em diversos momentos ao longo da pesquisa, percebe-se em Berthier a emergência do sujeito. Esse indicador foi construído inicialmente a partir de situações em que pareceu que Berthier não aceitava situações de imposição dirigidas a ele, tanto que, ao expressar no desenho em que foi proposto a mandala das representações sobre os papéis que ocupava em diversos contextos, Berthier ressaltou, marcando forte com a caneta, a representação de si mesmo como arrumador da casa. Seguindo a lógica da construção a pesquisadora, ao perceber a marcação acentuada, compreendeu que Berthier, assim como muitos jovens de sua faixa-etária, detesta ser chamado a cumprir com os afazeres domésticos preferindo gastar seu tempo com a internet e outras diversões. 
Figura 5 - Mandala feita por Berthier

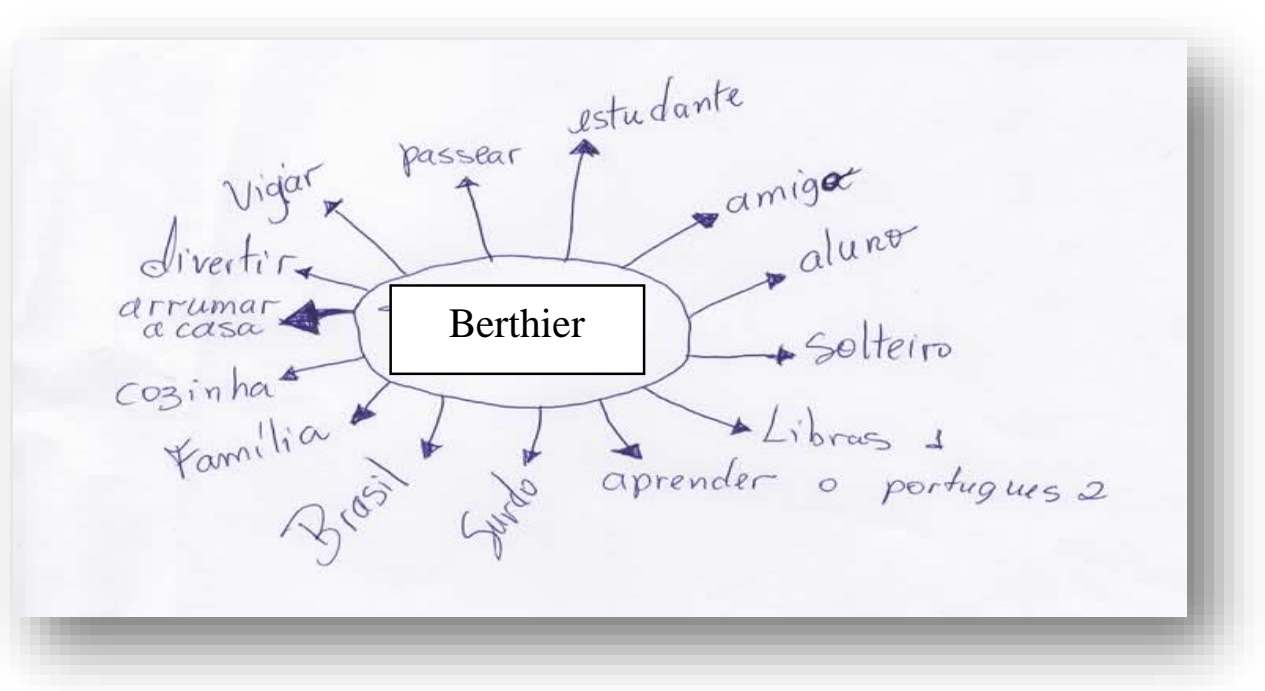

Fonte: Mandala feita por Berthier para representar os vários papéis que assume

No curso da mesma construção, em outro momento, Berthier revelou que não gostava de ir para casa mais cedo, para não ter que arrumar a casa (referindo-se aos dias em que não havia atendimento em horário integral na EB). Em conversa, afirmou que não se sente confortável com a cobrança da mãe para que faça os serviços domésticos no horário escolhido por ela. Durante o diálogo, a pesquisadora quis provocar o colaborador para o fato de que sua mãe chegava do trabalho cansada e necessitava de ajuda:

Pesquisadora: [EU ACHO EU TAMBÉM CHATA, VENHO AQUI E DEPOIS UNB ESTUDAR, CHEGO CASA CANSADA E COMEÇO GRITAR FILHAS LIMPAR CASA LOGO.] (Tentando comparar-se a mãe de Berthier para levar a reflexão sobre a responsabilização com os trabalhos domésticos).

Berthier: [SIM, VOCÊ CHEGA MUITO CANSADA].

Pesquisadora: [IGUAL MAMÃE, TAMBÉM CANSADA E PRECISAR DE AJUDA. EU CHEGO CASA CANSADA, CASA BAGUNÇA, FILHAS ASSISTINDO TELEVISÃO. TAMBÉM RECLAMO].

Berthier: SIM, MAM $\tilde{E}$ CANSADA IGUAL VOCÊ, MAS VOCÊ PENSA SUA FILHA GOSTA VOCÊ GRITAR, MELHOR VOCÊ FALAR NADA. FILHA SABE OBRIGAÇÃO VAI FAZER DEPOIS. EU NÃO GOSTO GRITO, FILHA NÃO GOSTA GRITO. VOCÊ PENSA O QUE ELAS GOSTAM? PARECE VOCÊ MESMO CHATA MÃE.

$\mathrm{Na}$ ocasião, a pesquisadora e Berthier conversavam sobre situações familiares e ele era conhecedor da constituição familiar da pesquisadora. Quando esta se posicionou em relação ao cansaço e à provável reação diante da desorganização e falta de colaboração das filhas, Berthier manifesta que os incômodos familiares são gerados não pela necessidade de contribuir com os afazeres domésticos, mas com os gritos da mãe para que os fizesse no horário escolhido por ela. O problema não é a intensidade sonora da fala da mãe, uma vez que ele não ouve. Berthier 
incomoda-se com o grito, que é um processo comunicativo, uma vez que a percepção de outros aspectos, como o corpo todo, se mostra em situação que ele chama de grito.

Resta lembrar, que tal interação dialógica, nos remete ao postulado por Bezerra (2014) de que o campo relacional da pesquisa é constituído de situações de conflito e tensão como qualquer espaço relacional. No caso em questão, a pesquisadora assumiu a postura de alteridade colocando-se no lugar da mãe de Berthier e tentando levá-lo à reflexão sobre suas responsabilidades no contexto familiar, porém acabou por refletir sobre a relação com as filhas e sua postura no próprio núcleo familiar. Essa reflexão ocorreu a partir da provocação de Berthier, visto que, o exercício da alteridade não consiste apenas em colocar-se no lugar do outro, mas modificar-se em razão dele (BARTHOLO, 2007).

A investigação quando assume o caráter relacional/comunicativo, torna-se, portanto, espaço de desenvolvimento para pesquisador e sujeito da pesquisa. Bezerra (2014) afirma em sua produção que a postura desafiadora do colaborador da pesquisa:

[...] se constituiu em um obstáculo a ser superado pela pesquisadora. Inseparável de uma produção de sentidos subjetivos por parte da mesma, o que, consequentemente, rompe com a ideia de neutralidade no processo de pesquisa. Consideramos que a emergência dos sujeitos envolvidos no momento empírico legitima-se na consideração da pesquisa como um espaço interativo, capaz de favorecer a expressão autentica de ambos os atores" (p. 104)

Retomando o conceito de González Rey (2004b) de que sujeito é o indivíduo ativo, intencional, reflexivo cuja emergência se potencializa em momentos de tensão e delas se nutre, inferiu-se que Berthier, inscreve-se como sujeito. A interpretação foi revelada não através dos momentos citados acima, e que levantaram o indicador em sua forma original, mas quando pelas ocasiões em que ele elabora estratégias criativas para comunicar-se em situações de tensão, por exemplo, quando manifesta em abaixo-assinado o direito a escolhas linguísticas, quando busca interlocutores capazes de acolher suas expressões ou mesmo quando indigna-se em situações conflituosas vividas no espaço familiar. Como confirmam as produções escritas, quando proposto o complemento de frases, revela: "Eu não gosto: obrigação".

\subsubsection{Entrelacando fios}

Berthier incomoda-se com as figuras autoritárias, ao mesmo tempo não se "assujeita" à pressões vividas, seja no espaço familiar, quando ocorre cobrança dos pais, ou em ambiente escolar, quando lhe foi exigido o uso da língua oral pela escola. Mais recentemente, indignouse com a cobrança de uma professora por atividades que não cumpriu. O que o incomodou, 
neste caso específico, não foi à cobrança da professora, mas o modo como foi exposto diante dos colegas como irresponsável.

Deste modo, compreende-se que as situações que fogem de seu controle o deixam extremante irritado. Essa constituição pode ser interpretada observando que mesmo se inscrevendo como usuário da língua portuguesa escrita e fluente no uso da língua de sinais, continua a enfrentar situações de conflito em seus processos de comunicação. Se diante dos surdos manifesta-se como superior aos que não sabem escrever e os convida a reflexão para mudança de atitude, ainda assim enfrenta as mesmas dificuldades que seus pares surdos em situações do cotidiano.

O jovem reage aborrecido aos apelos dos pais para que abandone o uso do celular e colabore com os afazeres domésticos. Apesar de parecer ser o ponto de conflito principal com a família, que muitas vezes atribuem ao filho o vício pelo uso de equipamentos eletrônicos. $\mathrm{O}$ ponto de tensão ocorre não pela cobrança pelos afazeres domésticos ou pela exigência de redução ao uso do aparelho celular, mas porque para Berthier essas ocasiões são subjetivadas como momentos de subordinação e retirada de seus direitos de escolha. Para além disso, estão as situações conflituosas que enfrenta na relação com o irmão e o pai dos quais nesse momento, manifesta-se contrário, mas não pode alterar. Esse pode ser o motivo de Berthier sempre se referir à família como configuração marcante em sua constituição, porém evitar permanecer em casa (TAVARES-SANTOS e MADEIRA-COELHO, 2015b).

A situação vivida na escola oralista em que Berthier elaborou abaixo-assinado, como relatado anteriormente, foi uma situação de tensão e produtora de sentidos subjetivos. A imposição do uso de língua oral em sua vida escolar o incomodava e, na ocasião, ele confrontouse com o instituído. Naquele momento, tinha consciência que através da Libras os conteúdos educacionais seriam mais acessíveis, essa constatação surgira das experiências vividas a partir da chegada da intérprete educacional. Sua decisão de permanecer na escola onde não era bem vindo, devido a suas reivindicações, trata-se de manifesta emergência do sujeito com escolhas próprias e que, portanto, não aceita a imposição a um único modo de comunicar-se, Berthier, de modo subversivo, saiu daquela escola apenas quando desejou e não quando foi "expulso".

Sendo o segundo filho surdo, quando Berthier nasceu, os conflitos vividos no momento inicial do diagnóstico da surdez do primeiro filho já haviam se acomodado no contexto familiar. Além disso, a mãe desde o diagnóstico da surdez de seu irmão, já trabalhava em escola com Surdos, para facilitar os atendimentos do primeiro filho. Aquele grupo familiar criara estratégias para lidar com os filhos surdos, desde a tentativa de oralização até a mudança do local de trabalho da mãe que anteriormente trabalhava em escola próxima a sua residência. $\mathrm{O}$ ambiente 
encontrado por Berthier, no que se refere à condição de surdo, naquele grupo familiar, já estava em processo de desenvolvimento e, deste modo, a situação do diagnóstico foi mais bem resolvida na família.

A escola de oralização ofereceu aos pais formação sobre as potencialidades das pessoas surdas e a importância da oralização. Por sua vez, a subjetividade social da escola em que a mãe trabalha também constitui essa mãe e consequentemente reconfigurou o grupo familiar a respeito de suas concepções sobre a pessoa surda, tanto que a mãe liderou o enfrentamento judicial para que seu filho tivesse acompanhamento do intérprete educacional, mesmo permanecendo na escola oralista.

A presença desse profissional intérprete e a relação constituída com Berthier também é marcante. Uma vez que, foram três anos de convivência diária e de diálogos abertos, como já relatado anteriormente. Essa interação foi favorável ao desenvolvimento de Berthier, pois em trabalho publicado anteriormente (TAVARES-SANTOS e MADEIRA-COELHO, 2015a) a intérprete exercitava a escuta sensível dos problemas pessoais dos estudantes e, ao mesmo tempo, os questionava constantemente sobre suas posturas. Essa relação, por conseguinte, foi constituindo um espaço de confiança, intimidade e reflexão (CORDOVA e TACCA, 2011).

Parece que o enfrentamento de sua mãe que possibilitou a presença do intérprete, tão marcante em seu percurso escolar, que contribuiu para que Berthier configurasse os enfrentamentos como favoráveis. O direito é subjetivado por ele como algo a ser respeitado, como no trecho que manifesta o desejo de obrigar as pessoas a falar em LS: "Eu queria obrigar, mas não posso fazer nada, porque cada um tem seus direitos”. Outro trecho que pode subsidiar a construção da pesquisadora é quando ele em situação de conflito após aplicação da prova do PAS, reconhece a importância da legislação e o quanto essa não é normalmente cumprida no nosso país. Porém exige que seja feito: “Mas a lei aqui é muito fraco. Afffff!!”.

No que se refere à comunicação, Berthier busca comunicar-se tanto com ouvintes quanto com surdos, tanto nas redes sociais quanto no contato face a face. Com os colegas surdos gosta de conversar e convida à reflexão sobre a necessidade do aprendizado da Língua Portuguesa, por vezes irrita-se com atitudes dos surdos que não buscam desenvolver-se. Aproveita essas situações para explicar as estratégias que permitem o aprendizado dessa língua e ensinar a língua portuguesa e para manifestar sua superioridade em relação a um grupo de surdos.

À medida que aprende a Língua Portuguesa e a utiliza de modo eficaz, Berthier cria estratégias peculiares para desenvolver seus aprendizados nessa língua. Tanto vendo filmes legendados, como perguntando o que não entendeu ou fazendo a datilologia, que significa, fazer a soletração do vocábulo em alfabeto manual. A datilologia de vocábulos novos é uma das 
estratégias utilizadas por alguns surdos como fazem alguns ouvintes com a leitura em voz alta quando desejam memorizar algo. Portanto, torna-se uma aprendizagem que se retroalimenta (TAVARES-SANTOS e MADEIRA-COELHO, 2015b).

Por sua vez, gosta de ensinar Libras e indigna-se com os esforços unilaterais para comunicar-se com alguns ouvintes. Mesmo conseguindo comunicar-se com o português escrito, vivencia situações de constrangimento e ausência de comunicação efetiva. Nem sempre age com passividade a essas situações, indigna-se e mantém postura firme quanto aos seus direitos e a criação de estratégias e sistemas de comunicação pertinentes para cada caso. Contraditoriamente, em outras situações mantém-se calado e atento, desconfiando se estão falando ou rindo dele.

O trabalho e a relação constituída com a intérprete transformou positivamente $\mathrm{o}$ atendimento educacional do estudante. Sendo essa, talvez a primeira interlocutora fluente em língua de sinais com quem estabeleceu relacionamento e onde as expressões poderiam ser livremente manifestadas em libras que é sua primeira língua. Portanto, Berthier possui outros interlocutores, mas manifesta a necessidade de alguém fluente em sua primeira língua.

Berthier constitui-se de modo positivo e exige autonomia, inscrevendo a surdez como condição e optando por vezes, pelos enfrentamentos para defender-se, já que, o desconhecimento e a intolerância são marcas da subjetividade social em relação às pessoas surdas nos países da América Latina (GONZÁLEZ REY, 2011a). Deste modo, constantemente Berthier utiliza recursos subjetivos como meio de superar as situações de tensão comunicativa causadas pelas condições sociais que a situação biológica impõe.

Berthier tem a intenção de se tornar professor e afirma que esse desejo é motivado pelo fato de ser uma profissão fácil e de segurança financeira, porém, observa-se que para além desses fatores, ele gosta de ensinar e se inscreve como alguém capaz de ensinar. Portanto, a escolha profissional, que pode ser ainda alterada, também passa por produções de sentido vivenciadas nos diversos campos de atuação de Berthier.

Todos esses fatos podem ter sido geradores de sentidos subjetivos que reforçaram a configuração de emergência de sujeito em Berthier. Uma vez que, se constitui em sua inteireza como pessoa de sentidos subjetivos articulados em sistemas que foram produzidos na sua história de vida, que em articulação com o momento atual e as produções subjetivas convertemse em ações (MITJÁNS MARTINÉZ, 2005). 


\subsection{Caso Vanessa}

Vanessa tem dezessete anos mora com os pais e uma irmã aproximadamente três anos mais velha, em cidade do entorno do Distrito Federal. Ensurdeceu em período pré-linguístico, ou seja, antes da aquisição de linguagem oral. Durante a infância, foi estimulada para desenvolver língua oral, o que não ocorreu e adquiriu a língua de sinais tardiamente, conforme relato da mesma, aproximadamente aos doze anos.

Vanessa, no espaço relacional da pesquisa, sempre respondia às perguntas e provocações como se não desejasse participar do diálogo. Também expressava bastante descontentamento e sono. No início da investigação, em 2014, a pesquisadora compreendeu que o desânimo de Vanessa pudesse se relacionar ao cansaço físico. Afinal, Vanessa mora em região distante da escola e, conforme relatou, sua rotina diária consistia em: acordar por volta de 4:30 h para conseguir chegar no horário de aula e no contra turno, tinha aula de segunda à quinta-feira, na escola de AEE oralista. Quando chegava em casa à noite, contribuía com os afazeres domésticos e concluía as tarefas de escola. Portanto, o tempo dedicado ao descanso era insuficiente, conforme relatado por ela.

É importante lembrar que durante a investigação, não foi possível realizar nenhum encontro com seus familiares. Apesar das várias tentativas da pesquisadora, as visitas eram sempre desmarcadas por Vanessa. Ela sugeria que o encontro ocorresse em outro espaço ou outra data. A recusa desses encontros por parte de Vanessa levou a pesquisadora a levantar o indicador de que no espaço familiar poderia haver algo que Vanessa não desejava mostrar.

Vanessa aparentava descontentamento durante os encontros e os contatos físicos, como abraços, ao final dos encontros com a pesquisadora, eram evitados. Essas situações incomodavam e instigavam a pesquisadora. Durante as férias escolares e até a qualificação dessa investigação, os contatos entre a pesquisadora e os colaboradores da pesquisa ocorriam apenas pela rede social Facebook. O primeiro encontro do ano de 2015 ocorreu em maio e a pesquisadora foi recebida por Vanessa com a seguinte afirmação: [VOCÊ SUMIU, AGORA SÓ FACEBOOK, PENSEI QUE ACABOU PESQUISA]. A expressão de Vanessa, levou a pesquisadora a compreender que a jovem gostava de participar da pesquisa, apesar de parecer desanimada.

É necessário reafirmar que no ano de 2015 a pesquisadora se propôs a permanecer na EB o dia inteiro, permanecia na sala de aula no turno matutino para observação dos sujeitos da pesquisa e no horário de almoço, onde normalmente conversava e observava os professores e 
demais estudantes. No turno vespertino, dispunha de um horário oficial para desenvolvimento da pesquisa. Era nesse espaço-tempo que eram propostas, as atividades da pesquisa.

No caso de Vanessa, houve um dificultador para esses encontros, pois permanentemente ela saia da escola depois do almoço e não continuava no horário integral. Tanto o fato de não aprofundamento nas respostas quanto a sua ida para casa mesmo nos dias pré-agendados para a investigação levaram a pesquisadora a hipotetizar que Vanessa não desejava participar da pesquisa. No modelo teórico adotado nessa investigação, uma das condições para compreender a subjetividade de uma pessoa é a percepção do quanto ela está implicada com a pesquisa e desejosa de contribuir. Daí a importância da construção e manutenção do cenário de pesquisa.

A pesquisadora optou por dar continuidade a investigação com Berthier e com Vanessa até que pudessem ter um encontro pessoal para questionar sua continuidade na investigação. No dia do diálogo intermediado pelo instrumento escolha de gravuras, que ocorreu em outubro de 2015, a escola estava mais vazia e o ambiente tranquilo, assim a pesquisadora quis aprofundar o diálogo para verificar a continuidade ou não de Vanessa como sujeito de pesquisa.

Em certo momento, a pesquisadora se sentiu desafiada pelo fato de Vanessa iniciar uma fala e depois cortar, delegando a Berthier o discurso sobre processos e vivências que pertenciam a ela. O diálogo transcorria sobre coisas do cotidiano familiar, mas quando esse assunto vinha à tona, Vanessa sempre se esquivava. Nessa ocasião se calou, constrangida. A pesquisadora arriscou: [PODE FALAR, EU NÃO FAREI FOFOCA DE NADA]. Anteriormente, Vanessa havia dito que, entre os surdos, existia muita fofoca e, por isso, a pesquisadora fizera a mesma escolha do termo fofoca, para manifestar que havia um pacto de confiança. Vanessa se irritou e fez alusão a levantar-se. Em seguida, manifestou aborrecida: [EU NUNCA DISSE VOCÊ FOFOCA, SE EU PENSO VOCÊ FOFOCA, EU NADA AQUI PESQUISA]. A pesquisadora, percebendo o erro na escolha linguística, começou a falar de situações vividas em sua juventude, os problemas de relacionamento com os pais e irmãos e como a pesquisadora compreendia, em sua juventude, essas situações. Com essa estratégia, buscava conquistar a confiança de Vanessa ao compartilhar de processos subjetivos no espaço relacional da pesquisa. A expressão da pesquisadora alterou o clima do encontro, pois Vanessa que até então se mostrava apática, dirigiu à pesquisadora o olhar atento e interessado. A emocionalidade e cumplicidade presente na troca entre essas duas mulheres fez emergir ali sentidos subjetivos inesperados. Até porque os sentidos subjetivos, não são controlados por quem os produz. A pesquisadora chorou ao se lembrar de fatos de sua juventude que foram doloridos. Não foi uma simples fala ou relato de fatos vividos, mas abertura a processos emocionais configurados pela 
pesquisadora, os quais, sem intencionalidade ou consciência, surgiram na ação comunicativa. O ponto crucial para o desenvolvimento da pesquisa com Vanessa ocorreu nesse momento.

Ao final desse encontro, ocorreu um abraço diferente dos que sempre marcavam o final dos encontros da pesquisa e dos quais Vanessa, por vezes, se esquivava. A pesquisadora não sabe aqui precisar quão diferente foi esse abraço, por trata-se de processos subjetivos dos quais a pessoa que os produz não é capaz de compreender em sua inteireza - talvez uma cumplicidade singular, algumas vezes construída entre as pessoas. Após esse dia, Vanessa arriscou trocas de mensagens no Telegram com a pesquisadora, fato que nunca ocorrera anteriormente.

Compreendendo um pouco da história de Vanessa e a respectiva adesão na investigação, resta apresentar as construções e interpretações da pesquisadora sobre Vanessa.

\subsubsection{Eu preciso pertencer: fazendo parte de um grupo de amigos}

As relações instituídas são importantes para o desenvolvimento da pessoa. Para os jovens, é nas relações com os amigos que trocam experiências e falam de suas vivências. Vigotsky $(1997,2007)$ fala da importância da coletividade e da troca entre os pares para o desenvolvimento, uma vez que na coletividade se estabelecem diálogos autênticos (VIGOTSKY, 1997). No caso de Vanessa, podemos interpretar a partir de seus relatos sobre a relação com as vizinhas e em suas expressões via redes sociais que as relações com colegas ouvintes se constituíam em passeios, festas, paqueras, como qualquer jovem de sua faixa etária, porém a comunicação era apenas para combinar ou para mostrar algo, mas não para o estabelecimento de diálogos autênticos.

Conforme relato da mesma, durante os encontros presenciais, Vanessa não costuma dialogar, uma vez que grande parte dos colegas ouvintes costuma se interessar por Libras para aprender apenas termos de xingamento, o que não permite uma comunicação efetiva. Esse modelo de comunicação, parece comum entre ela e as pessoas ouvintes que não conhecem Língua de Sinais e esses encontros não orientam para o seu desenvolvimento, pois não permitem a troca de pensamentos com o outro, nem ocorre o divergir e concordar, que nutrem o pensamento conforme postula Freire (1983).

Para Vanessa, os encontros com as amigas ouvintes são prazerosos, ainda que a comunicação não avance ao nível do diálogo. Nesses momentos, sente-se parte do grupo de amigas de sua vizinhança. Quando a pesquisadora questionou o que faziam juntas, disse que comiam pizza, conversavam ou tiravam fotos. A pesquisadora questionou quais os principais temas dessas conversas com as amigas. Vanessa balançou o ombro e disse que escrevia no 
celular. Para ela, esses momentos são importantes pela companhia e não pelo nível de comunicação estabelecido. Estar junto, ou melhor, sentir-se junto vale mais que dialogar. Afinal, Vanessa não tem fluência na língua portuguesa o que impede de estabelecer diálogos com interlocutores que não são usuários de LS. Nesse caso, sente-se parte do grupo das jovens que moram naquela região e sente-se aceita como é, não exigindo diálogos. Não se trata de uma aceitação plena e propiciadora de desenvolvimento para Vanessa, porém esse grupo social permite que ela permaneça fora do ambiente familiar.

Os interlocutores de Vanessa, nas redes sociais, são Surdos ou pessoas da comunidade surda, pelo modo como escrevem e se expressam em interlíngua, ou seja, não obedecem nem as regras gramaticais de LS e nem da língua portuguesa (QUADROS \& KARNOPP, 2004).

\subsubsection{Meu verdadeiro divã, a intérprete educacional}

Vanessa manifesta que não gosta de falar de si, que é reservada, porém na relação constituída com a intérprete educacional ganhou confiança e estabeleceu uma relação para além do instituído na escola. Essa relação parece ter sido produtora de sentidos subjetivos favoráveis ao desenvolvimento de Vanessa, à medida que compartilhava suas vivências tinha a oportunidade de refletir sobre elas, já que a intérprete era questionadora.

A própria postura da intérprete que estabelecia com Vanessa o diálogo desenvolvedor é manifestada em sua expressão quando diz:

\footnotetext{
Joana: O ser humano não é só língua. Eu era alguém mais velho que eles podiam conversar e tirar dúvidas sobre qualquer assunto. Vanessa demorou um pouco, apenas quando percebeu que tínhamos uma relação de confiança é que foi se soltando (expressão da intérprete para outra produção (TAVARES-SANTOS e MADEIRACOELHO, 2015a).
}

A relação estreita constituída com a intérprete educacional com quem conviveu durante três anos parece não ter sido construída ainda com nenhum professor da EB.

No segundo semestre de 2015, a intérprete fez uma visita à EB para verificar como os ex-alunos estavam. Após esse dia, Vanessa expressou a alegria, conforme excerto:

\footnotetext{
Pesquisadora: [COMO FOI A VISITA DA INTÉRPRETE?]. Vanessa: [MARAVILHOSA. MUITA SAUDADE].

Pesquisadora: [VOCÊ SAUDADE? EU PENSEI QUE SEMPRE ENCONTRAVA COM ELA] (querendo saber se continuava manter contato com a intérprete)

Vanessa: [EU JÁ FUI DUAS VEZES VISITAR, PRECISA COMBINAR ANTES].
} 
Diante da afirmação de Vanessa sobre encontros com a intérprete, Berthier se manifestou contrário à atitude, afirmando que a intérprete tem muitas ocupações e portanto não pode utilizar de seu tempo para se relacionar com ex-alunos, Vanessa respondeu que continuava falando à noite e que ela respondia normalmente, ou seja, após a mudança de escola, Vanessa parece não ter construído outra relação que possa atuar como "sujeito comunicador" onde haja a troca, ativa e intencional dos próprios processos e experiências subjetivadas.

Além disso, a chegada da intérprete na vida escolar de Vanessa, ainda na escola comum, marcou o início de uma relação afetuosa bem como um maior desenvolvimento linguístico em Libras. Até a chegada da intérprete, Vanessa, que adquiriu tardiamente a LS, possuía um vocabulário restrito que impossibilitava o diálogo mais íntimo sobre questões que envolvem seus sentimentos. Esse fato não pode ser atribuído à impossibilidade de esse diálogo ser feito nas línguas de sinais, de acordo com Chamberlain e Mayberry (2008), as línguas gestuais permitem acesso a temas aprofundados sobre tópicos abstratos, possibilitando a criação de metáforas, poesias e dramas.

A intérprete educacional além de enriquecimento do vocabulário, foi significada para Vanessa pela possibilidade de um diálogo que permitisse expressar seus próprios processos subjetivos e questões relacionadas a como se sentia nas situações vividas, sendo interlocutora ativa.

\subsubsection{Escola}

A escola é um espaço onde os jovens permanecem um tempo considerável, no caso dos surdos, filhos de pais ouvintes, esse espaço pode ser o único para trocas dialógicas e interações comunicativas. Além disso, os surdos ocupam grande parte de sua rotina na escola, pois além das aulas, recebem os atendimentos educacionais especializados. No caso das escolas com filosofia oralista e, além dos atendimentos educacionais, os estudantes recebem atendimentos fonoaudiólogos. Portanto, a escola é um espaço de produção subjetiva para as crianças e jovens surdos.

No caso de Vanessa, as produções sobre a escola foram desenvolvendo-se no movimento da pesquisa. Conforme expressão abaixo manifestada no início da pesquisa, quando estudava em escola comum e com a intérprete, a partir do instrumento complemento de frases:

Sinto falta: faltam professores aprender libras em mãos.

Os meus professores: eu acho um pouco chato, porque professora explicar, eu odeio longa explicação. 
O que eu gostaria: Eu quero estudar com professores que saibam libras (esse trecho escrito foi interpretado para língua portuguesa).

Sob essa mesma ótica, no momento inicial da pesquisa, ela manifestou na utilização do mesmo instrumento, complemento de frases: "Na escola me sinto [HORRÍVEL]". Virou-se para a pesquisadora e perguntou [POSSO ESCREVER HORRÍVEL?] após aprovação, ela escreveu: Que horrível. No diálogo estabelecido nesse dia ela expressou a dificuldade de comunicação com os professores que não conhecem a língua de sinais e reclamou das longas explicações dadas pelos professores da escola inclusiva.

As produções de Vanessa nos permitem dizer que ela considera que a escola é horrível porque a intérprete não consegue acompanhar a explicação dada pelo professor, as explicações são longas e não respeitam o tempo dos surdos. Na dimensão do imaginário, Vanessa desejava estudar em uma escola onde todos os professores soubessem a língua de sinais. Naquele momento, em 2014, ela considerava que o fato de não compartilhar do mesmo código linguístico com os professores era o motivo de seu descontentamento com a escola que, para ela, era horrível.

No ano seguinte, após alguns meses na EB, quando utilizado o instrumento de escolha de gravuras, Vanessa escolheu a seguinte gravura para representar a escola:

Figura 6 - Gravura escolhida por Vanessa para representar escola

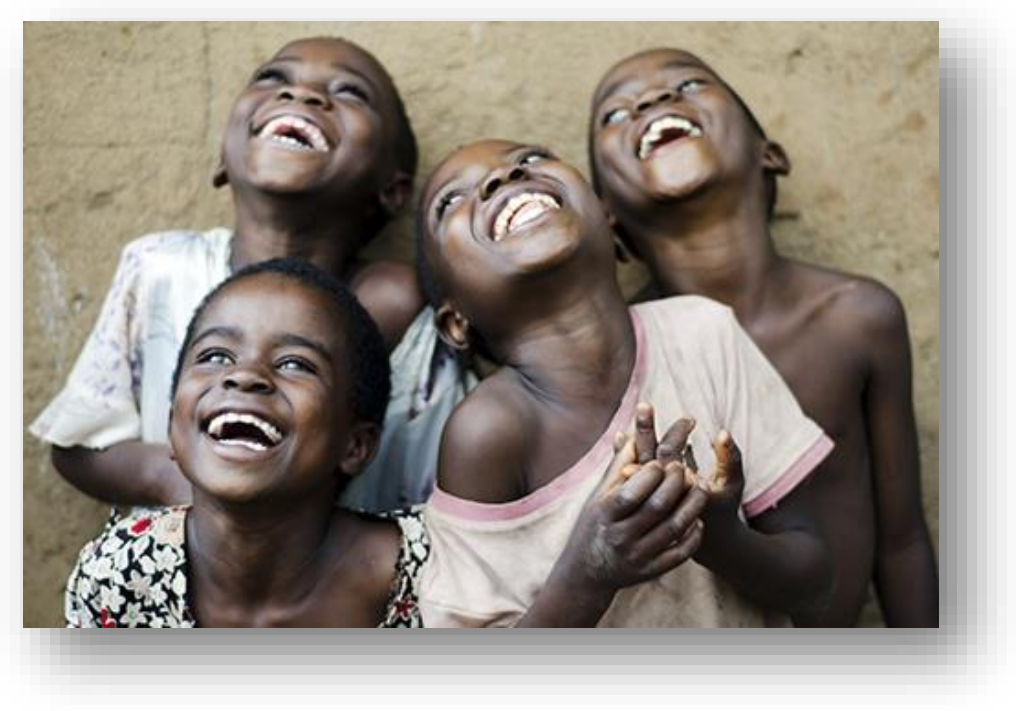

Fonte: Arquivo do trabalho desenvolvido em sala

No diálogo após a escolha da gravura, ao ser provocada pela pesquisadora, manifestou: 
A pesquisadora provoca: [ESCOLA HORRİVEL?] (Fazendo referência a resposta dada no ano anterior no complemento de frases. Vanessa repete o sinal, pensando haver dificuldade na compreensão da Libras por parte da pesquisadora). Antes disso, Vanessa questiona: [ESCOLA INCLUSÃO?] (Referindo-se a escola do ano anterior) Pesquisadora: [NÃO AQUI].

Vanessa continua: [HORRÍVEL, NÃO ALEGRIA]. (Repete o sinal de alegria, faz devagar para que a pesquisadora compreenda).

Pesquisadora (pede desculpas, como se realmente não houvesse entendido o sinal e dá continuidade): [ALEGRE PORQUÊ?].

Vanessa: [ESCOLA ALEGRE PORQUE ENCONTRA AMIGOS, BATE PAPO LIVRE].

Nessa ocasião - ainda que pensasse que a pesquisadora não tinha compreendido o termo - Vanessa, quando vê o sinal "horrível", imediatamente se reporta à escola anterior, o que indica que, de fato, a escola de inclusão era configurada como horrível. Atualmente, porém, a nova escola é considerada por ela como espaço de alegria e de encontro com os amigos. Esse olhar sobre a EB não apaga as produções vividas na escola anterior, que para ela continuam sendo significadas como como "horrível". Na realidade, Vanessa produz sentidos subjetivos nas vivências desse espaço e, em setembro de 2015, expressa que percebe e pontua os pontos negativos da EB, onde estuda atualmente.

Conforme manifesta em situação de conversa informal em que a pesquisadora levanta o tema escola e como se sentem por estar lá. Na ocasião, ao ser indagada se gostava da escola, ela responde:

\footnotetext{
Vanessa argumenta: [GOSTO MUITO, MARAVILHOSO].

Pesquisadora: [POR QUÊ?].

Vanessa continua: [PORQUE MATÉRIA MAIS CLARO, ENTENDE FÁCIL]. Vanessa vai andando em direção à porta e pondera: [TEM PROFESSOR AQUI QUE NÃO SABE MUITO LÍNGUA DE SINAIS, ALGUNS SABEM PROFUNDO, OUTROS APRENDENDO]. (Dirigindo olhar desanimado ao professor que está na sala no momento).
}

Vanessa leva em conta os pontos positivos da EB, porém não deixa de considerar as dificuldades e limitações da instituição. Percebe-se sua postura reflexiva diante da situação, portanto, a escola e as experiência vividas nesse contexto, como a relação com os novos colegas surdos, a busca por estratégias que contemplem os recursos visuais, o uso da língua de sinais e, principalmente, a intenção comunicativa dos professores com os estudantes podem ser consideradas como geradoras dessas produções.

Vanessa em suas produções revela ainda uma postura contraditória e reflexiva, quando escolheu a gravura citada anteriormente, manifestou que os surdos também são fofoqueiros e que isso a incomodava imensamente. $\mathrm{Na} \mathrm{EB}$, os surdos dialogam e se relacionam entre si e, no movimento dessas relações, muitas vezes, os surdos manifestam o desejo de não conviver com 
outros surdos, porque os consideram fofoqueiros. O número de interlocutores pode ser reduzido, já que poucos falam em língua de sinais.

Podemos interpretar que Vanessa configura a escola comum como lugar horrível pela ausência de intencionalidade comunicativa com os professores. A escola bilíngue, porém, é configurada por ela como espaço de alegria, lugar de encontro com os amigos, mas não deixa de pontuar os pontos negativos dessa escola, onde nem todos os professores sabem libras e como lugar favorável ao aprendizado de língua portuguesa.

\subsubsection{Família: lugar de segregacão}

Vanessa, em suas expressões pouco se refere à família, quando fala de momentos agradáveis remete-se a Berthier, a intérprete educacional, as vizinhas e às amigas da escola bilíngue. Na escolha livre de gravura, escolhe a seguinte para representar a irmã:

Figura 7 - Gravura escolhida por Vanessa para representar a irmã

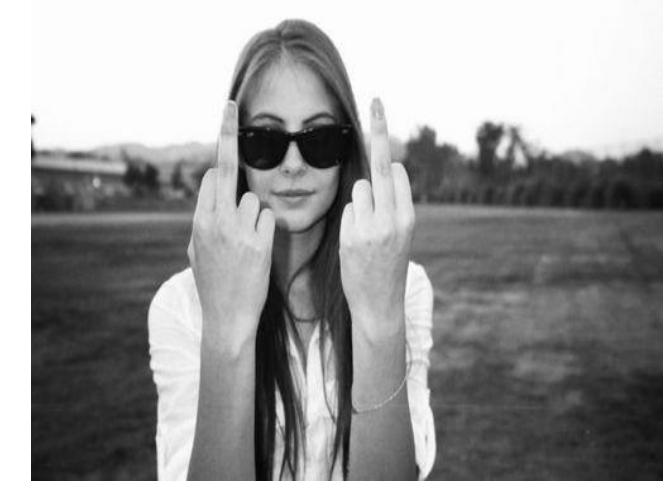

Fonte: Arquivo do trabalho desenvolvido em sala

Após essa escolha, durante diálogo, manifestou que em situações que deseja conversar com a irmã para compreender algum diálogo ocorrido na família, programa de televisão ou para tirar dúvida sobre vocabulário para escrever, a irmã não se importa e nem manifesta intenção de colaborar. Em função disso, Vanessa expressa em relação a irmã: “foda-se".

Importa pontuar, que Vanessa possui uma tatuagem no braço com a seguinte declaração: "Mãe, amor eterno". Em determinado momento, em conversa espontânea, a pesquisadora questionou o que havia escrito. Vanessa imediatamente manifestou que faltava fazer a tatuagem do pai. Quando falou o significado da tatuagem, a pesquisadora provocou: [QUE BOM AMOR ETERNO MAMÃE E PAPAI]. Vanessa sacudiu os ombros, fez uma expressão de 
descontentamento e esquivou-se iniciando diálogo com uma colega surda que passava no corredor.

Essas expressões e outras manifestações em diálogos permitiram à pesquisadora indicar que apesar da tatuagem, Vanessa configura a família como um grupo do qual ela não participa. A imagem que escolheu para sua família e as expressões acima relatadas explicam essa construção.

Figura 8 - Gravura escolhida por Vanessa para representar família

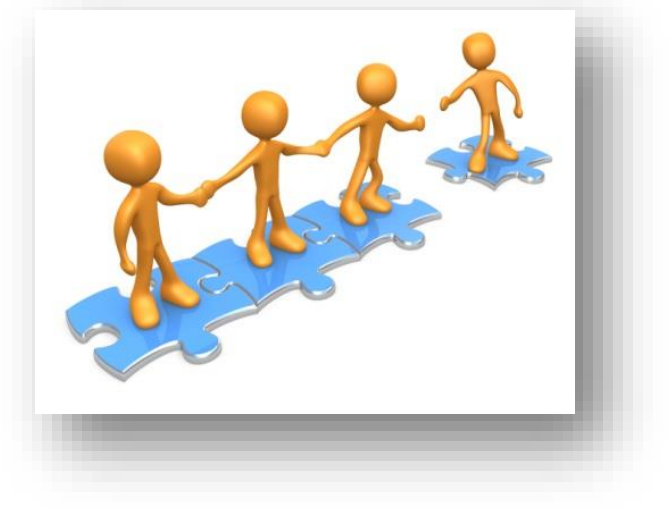

Fonte: Arquivo do trabalho desenvolvido em sala

Na escolha de gravuras, quando mostrou a ilustração à pesquisadora, essa falou que era uma boa gravura, porque mostrava uma pessoa separada das outras e todos tentando se aproximar novamente. Depois disso, Vanessa respondeu que havia escolhido o desenho errado, pois o desenho não representava a sua família. Vanessa disse: [DESCULPA, ESCOLHI DESENHO ERRADO]. Enquanto, apontava os bonecos que representavam os familiares, referindo-se ao fato de que apenas ela buscava aproximação com os familiares. A comunicação utilizada pelos familiares é subjetivada por ela como discurso de segregação e desvalorização, ela atribui ao fato de sua condição de surda. Quando compara seus direitos aos da irmã e ao ser questionada se não se trata de questão da idade, ela faz o sinal de surdez e escapa do assunto.

\subsubsection{Entrelacando fios e tramas}

As relações de Vanessa com os colegas ouvintes e familiares são superficiais e de pouca intimidade. As produções subjetivas de Vanessa apontam para a insegurança em relação aos vínculos afetivos, estendendo-se às relações familiares, às relações com colegas ouvintes e surdos e também em relação ao envolvimento com a pesquisa e com seus processos de aprendizagem. 
Ela mostra a necessidade de afeto, quando se interessa pela história de vida da pesquisadora, quando busca constantemente a intérprete para trocas dialógicas e na relação que estabelece com Berthier. Porém, essa necessidade é mascarada em uma postura de desânimo constante.

Outro ponto, porém, é que Vanessa parece não envolver-se emocionalmente com a aprendizagem e com as tarefas propostas pela escola, apesar de cumprir com todas as atividades. Vanessa não permanece na escola em tempo integral, sempre que possível vai embora no horário de almoço, ao ser arguida sobre o motivo de não permanecer na escola, manifesta que deseja ir para casa.

Considera-se que tal atitude, para além da falta de envolvimento emocional que estabelece com as pessoas da escola é também uma tentativa de estar por mais tempo no espaço familiar, como se o tempo que permanecesse em casa pudesse modificar a relação e seus familiares.

O sistema complexo de constituição dos surdos está para além da condição que a surdez impõe. No caso de Vanessa, os processos de comunicação vividos no espaço familiar e em outros espaços sociais historicamente vão constituindo sua subjetividade individual como uma jovem que pouco se expressa, pouco se dispõe a participar de diálogos.

Quando no complemento de frases adaptado em vídeo surge a seguinte frase: [SOU FELIZ], Vanessa demorou a dar resposta e repetiu o item como se não pudesse compreender. Depois que a pesquisadora explicou: [SOU FELIZ, SIGNIFICA QUAL MOMENTO, LUGAR VOCÊ É FELIZ?] Vanessa, não se inscreve como alguém feliz e afirma não ter compreendido. Mesmo nas situações que poderiam ser agradáveis, como no próprio relato sobre brincadeiras feitas pelo pai, ela configura como agressão porque ela é surda.

Vanessa se sente inferior à irmã que, segundo ela, goza de liberdade e privilégios dos quais ela não desfruta por ser surda. A condição da surdez é configurada por ela como menos valia para todos os contextos sociais nos quais ela está envolvida.

\subsection{A relação de Berthier e Vanessa}

A pesquisadora optou desde o início por manter os encontros em dupla e esse formato, durante um certo tempo, foi favorável por permitir considerar a relação entre Vanessa e Berthier.

Aos poucos foi perceptível a relação de poder exercida por Berthier em relação à Vanessa. Ele exerce uma autoridade sobre Vanessa, mesmo que posicione ser contra esse tipo 
de postura. Em seus relacionamentos com outros colegas e mesmo em suas publicações, Berthier chama os surdos à reflexão e se mostra solícito em contribuir com o desenvolvimento do outro. No texto do abaixo-assinado, já citado, e em outras publicações deixa claro o direito de escolha do outro, provocando sempre a reflexão.

Vanessa subjetiva a relação como se estivesse em postura inferior à Berthier. Possivelmente motivada pelo fato de que Berthier tem um irmão surdo, ainda que esse pareça ausente das relações familiares, possibilitou que Berthier adquirisse a língua de sinais. Além disso, Berthier tem liberdade para participar de festas e eventos com colegas surdos ou ouvintes. Ele participa de viagens e passeios com familiares, que permite a convivência com outros grupos sociais e a possibilidade de constituir-se subjetivamente nesses grupos. A família de Berthier possui um olhar para a potencialidade da pessoa surda, que se expressam nas ações da mãe e na relação constituída entre ela e o filho. Isso não impede que ocorram momentos em que Berthier se sinta excluído dos processos dialógicos estabelecidos pelos familiares, em festas ou em reuniões de família. Berthier adquiriu a primeira língua e sabe da importância da aquisição da língua portuguesa sendo portanto mais fluente que Vanessa nessa língua.

Todas essas condições parecem subjetivadas por Vanessa como situações de menos valia, exigindo proteção por parte do colega. A proteção exercida por ele, por outro lado, é discursada como aconselhamento. Deste modo, ele pode exercer a liderança e o papel de ensinar ao passo que ela pode desenvolver uma relação de intimidade e confiabilidade. Em alguns momentos da pesquisa, quando provocada a falar de seus próprios processos, Vanessa sempre se referia a ele dizendo que ele conhecia sua história, como que legitimando a ele a possibilidade de falar por ela, condição recusada pela pesquisadora. A relação entre os dois torna-se confortável por legitimar configurações subjetivas constituídas pelos dois sujeitos.

Durante as aulas e atividades observadas, Berthier e Vanessa sempre dirigiam olhar um ao outro, um diálogo ou provocação em uma relação de profundo afeto. Daí a explicação de que na ocasião da mudança de escola, os estudantes exigiram dos pais a decisão coletiva para que permanecessem juntos. Existe uma relação de cumplicidade entre os dois.

Porém na nova escola, a relação exposta passa por uma nova configuração. Durante anos, os dois estudantes eram os únicos surdos sinalizadores na mesma sala. Nesse caso, havia uma necessidade de proteção entre eles, mesmo quando houve mais uma estudante na sala, pois essa era oralizada. Na EB, porém, Vanessa ousa buscar outras relações com jovens de sua idade. Esse novo momento da relação pode ser favorável ao desenvolvimento de ambos, uma vez que atualmente a relação os coloca em situação confortável na qual cada uma assume papel previamente estabelecido. $\mathrm{O}$ fato de afastarem-se e permitirem a participação de outros atores 
pode fazer com que reconfigurem a relação de maneira favorável ao desenvolvimento de ambos com a produção de novos sentidos subjetivos, uma vez que irão assumir novos papéis que não estão cristalizados.

Além disso, a chegada da intérprete na vida escolar de Vanessa marcou o início de uma relação afetuosa bem como o enriquecimento de seu vocabulário em Libras. Até então, Vanessa possuía vocabulário restrito que impossibilitava o diálogo mais íntimo sobre questões que envolvem seus sentimentos. A aquisição de linguagem tardia e o escasso vocabulário disponível na língua gestual de seu país, a Libras, não permitia até então que Vanessa mantivesse um diálogo mais aprofundado. A intérprete educacional além de enriquecimento do vocabulário abriu para ela a possibilidade de falar de seus próprios processos e de questões relacionadas à como se sentia nas situações vividas.

Por sua vez, com Berthier, a intérprete construiu uma relação afetuosa e de possibilidade de expressões de suas vivências e, mesmo com a facilidade que Berthier tem de buscar interlocutores, a intérprete foi aquela com quem ele podia expressar-se no mesmo código linguístico. Portanto, as expressões foram mais fluídas que com outros interlocutores ouvintes. Naquele espaço de convivência que eles construíram, havia o diálogo franco e aberto. A intérprete construiu com os dois jovens uma comunicação desenvolvedora. A medida que cobrava postura reflexiva dos estudantes, a própria intérprete nutria-se do desejo de aprimorar seus conhecimentos, conforme pesquisa anterior (TAVARES-SANTOS e MADEIRACOELHO, 2015a).

A configuração subjetiva que Vanessa e Berthier possuíam de professor fluente em LS é embasada na vivência que construíram com a professora intérprete com quem estudaram durante três anos. Na dimensão idealizadora eles chegam à escola bilíngue compreendendo que encontrariam espaço para o diálogo e as discussões como tinham com essa intérprete. Porém se deparam com uma realidade diferente. Existem professores fluentes em Libras que não buscam uma relação interacional com os estudantes, existem professores e profissionais da educação que ainda não são fluentes em Libras, mas desejam se comunicar e estabelecer uma relação de afeto e confiabilidade, assim como existem professores que possuem fluência em LS e que desejam estabelecer relações e diálogos com os estudantes. Uma delas iniciou com Berthier uma relação dialógica para além do relacionamento profissional, conforme expressado por ele. Já com Vanessa, esse fato não foi observado.

Na EB os estudantes possuem bloquinhos de notas, como se fosse um pequeno glossário, para o registro de palavras em língua portuguesa. Outros fazem semelhante registro no aparelho celular. Entretanto, não foram observados tais comportamentos por parte de Berthier ou 
Vanessa, ele, quando se depara com um vocábulo novo ele digitaliza várias vezes, como se estivesse falando em voz alta para memorizar. 


\section{CONSIDERAÇÕES ATUAIS}

Rotomo o objetivo geral dessa investigação que foi compreender elementos das configurações subjetivas de dois jovens surdos e o modo como subjetivaram processos comunicativos vividos em diferentes contextos. Considero ter cumprido com o que me propus inicialmente.

Pretendia-se ainda, caracterizar e conhecer processos comunicativos utilizados pelos jovens Surdos colaboradores desta pesquisa e compreender aspectos da subjetividade individual desses jovens.

Em virtude do que foi mencionado ao longo desse estudo, considera-se que falar de relação entre pessoas surdas e ouvintes envolve pensar em aspectos históricos, sociais, biológicos, de comunicação e linguagem, em constituição individual e social. Todos esses aspectos são configurados como produções subjetivas. Portanto, considerar a constituição subjetiva da pessoa humana requer um olhar para complexidade.

No caso dos Surdos, compreende-se ainda, que os processos de comunicação vividos são produtores de sentidos subjetivos. Os Surdos são privados e desafiados linguisticamente constantemente. As situações de comunicação serão em algum ou em vários momentos situações de tensão para as pessoas surdas. Deste modo, Surdos oralizados, implantados, sinalizadores, filhos de pais surdos ou filhos de ouvintes, com fluência da língua escrita ou não, com fluência na língua oral de seu país ou não, participam de situações de tensão vividas em experiências comunicativas cotidianas. Essa peculiaridade é corriqueiramente enfrentada e assim, os processos comunicativos/dialógicos se organizam como momentos favoráveis à produção de diferentes sentidos subjetivos. Não se trata de uma produção homogênea, pois cada Surdo se constitui da subjetividade social dos espaços sociais que participa. Mesmo o termo comunidade surda deve ser utilizado no plural, pois cada comunidade é heterogênea. Existem comunidades surdas religiosas, acadêmicas, de lazer, de entretenimentos artísticos e outras. Por vezes, alguns surdos participam simultaneamente em mais de um desses grupos comunitários, para além dos grupos sociais, predominantemente ouvinte, com os quais convivem.

As configurações subjetivas de comunicação podem ser, e provavelmente serão, "configurações subjetivas dominantes" (GONZÁLEZ REY, 2007, p. 137) do Surdo, participando de outras configurações, uma vez que para González Rey (2005):

A linguagem precede o sujeito como estruturação simbólica do social, no entanto, o advento do sujeito assume essa linguagem de forma diferenciada e subjetivada: a linguagem encontra nesse advento do sujeito um novo momento de sua constituição subjetiva, que tem caráter singular (p. 228-229). 
Nesse trabalho compreendemos que ainda que a comunicação seja configuração subjetiva dominante nas configurações da ação das pessoas surdas, não se pode reduzir a pessoa surda à sua comunicação. A constituição da subjetividade individual dos sujeitos de pesquisa pôde ser percebida como uma constituição singular. Apesar de os dois participantes da pesquisa terem um percurso educacional compartilhado, cada um deles se constitui de modo diverso.

Entendo que, no contexto histórico atual, no modelo de inclusão proposto aos estudantes surdos na SEDF, há escolas que possuem apenas um ou dois estudantes surdos matriculados. Nesses casos, pode haver generalização do surdo em comparação com o ouvinte, o que Kelman e Buzar (2012) pontuam como a invisibilidade do estudante surdo na escola comum. Postura que dificulta observar a história e constituição de cada um deles. Nesses casos, o que pode ocorrer é a generalização de ações e constituição desses estudantes nomeados como comuns aos surdos. Mais recentemente o termo cultura surda tem sido utilizado no senso comum para homogeneização dos Surdos, muitos professores que atuam na educação de surdos utilizam em seu discurso o termo cultura surda para generalizar e homogeneizar, mostrando que o termo tem sido usado sem o aprofundamento do seu conceito.

Considero ainda, que as EB pode ser local de confronto, tensão e acomodação da diversidade dentro do grupo de Surdos. Talvez a convivência entre surdos oralizados, implantados e sinalizadores, com diferentes níveis de apropriação da língua de sinais e da língua portuguesa, possa contribuir para minimizar as divisões percebidas na comunidade surda no contexto geral. A EB é o espaço da diversidade de professores de surdos, com os mais variados níveis de aprendizado da língua de sinais e os mais variados olhares para com os surdos e suas potencialidades.

Nesse cenário, proponho que a EB por ter um quantitativo amplo de surdos matriculados, deva ser espaço para que os professores de outras escolas discutam a diversidade existente dentro do grupo de surdos. Sugiro, iniciar essa discussão no seio da Escola Bilíngue e que os professores da Secretaria se aproximem da EB para essa discussão. O compartilhamento dos próprios processos entre os estudantes e professores dessa escola e os da rede pode favorecer o desenvolvimento dos estudantes e profissionais.

Além disso, na EB, o currículo e o trabalho propostos seguem o modelo da escola tradicional. Portanto, apesar de ser uma escola inovadora do ponto de vista de sua proposta inicial e implementação, segue o modelo vigente de currículo e avaliação, com isso perde a 
possibilidade de avançar qualitativamente para a autonomia dos estudantes surdos ali matriculados.

$\mathrm{Na}$ atualidade, ocorrem mudanças estruturais na sociedade. Os contratos sociais são alterados a partir das reivindicações do que diferencia os grupos humanos, como os enfretamentos pelo respeito à diversidade sexual, de etnia, de gênero, de classe e de língua. A sociedade busca um novo paradigma, o da fluidez e da constituição singular das pessoas. Os trabalhos de Emerton, 1998; Coelho, Gomes, Cabral \& Coelho, 2006; Gomes, \& Cabral, 2007; Silva, 2010; Rocha, 2015 alertam para um novo tempo, uma virada nos discursos e ações para romper com as dicotomias e modelos hegemônicos surdos e ouvintes ou surdos sinalizadores e oralizados. A partir de Emerton (1998), sociólogo surdo, pode-se afirmar que o discurso e as ações de dominação de ouvintes sobre os surdos não tem mais espaço, tampouco a exigência de oralização. Neste cenário, cabe o olhar para a constituição singular da pessoa humana, para o percurso histórico, para um novo currículo que privilegie as diferenças e potencialidades.

Além disso, os Surdos vivenciam na escola problemas comuns, como os problemas de formação inicial e continuada do professor que não contemplam a diversidade. Como pudemos observar em situações da EB onde os professores esforçam-se para criar novas práticas e ainda se perdem nessas tentativas, talvez por falta de formação que contemple o diverso.

Em relação à formação de profissionais que pretendem atuar com esse alunado, considero a necessidade de contemplar nos cursos de formação os aspectos dialógicos e relacionais e a importância de interações direcionadas para o desenvolvimento dos estudantes surdos. De um modo geral, a formação desses profissionais tem privilegiado o aprendizado da língua de sinais, como se esse fosse a único fator importante para o desenvolvimento desses estudantes.

Estudantes surdos em situação de inclusão permanecem por muitos anos estudando com os mesmos colegas, como é o caso dos sujeitos dessa pesquisa. Além disso, a rotatividade entre professores no atendimento a eles também é minimizada, como no caso da intérprete educacional que permaneceu com os sujeitos de pesquisa durante quatro anos. Esse tipo de situação pode desfavorecer o desenvolvimento dos estudantes e dos profissionais.

A partir de González Rey (2011), considero que a discussão sobre a diversidade de surdos e dos respectivos desenvolvimentos pode contribuir para que os estudantes se constituam a partir do olhar da diferença (GOMES, CABRAL \& COELHO, 2006). Afinal, conforme González Rey (2011), as configurações subjetivas produzidas socialmente em torno da pessoa com desenvolvimento atípico são constituídas a partir do medo, da inferioridade e da 
insegurança em uma trama simbólica onde participam crenças, representações sociais e discursos socialmente produzidos.

Espera-se que esse trabalho seja um provocador de reflexões sobre as questões que envolvem a constituição singular dos estudantes Surdos e em relação à avaliação da EB e de sua atuação no cenário da educação de surdos do DF.

As construções sobre os valores e representações em torno da EB apresentadas de forma inicial nessa produção, suscitam o desejo de implementar outras investigações acerca da constituição subjetiva dos surdos. Assim, fazem parte de um conjunto de inquietações para futuras pesquisas, dentre elas: Como se dá a produção subjetiva de surdos em situação de isolamento linguístico e sem uma comunicação efetiva? Qual a relação entre a visualidade e os processos simbólicos?

Como ponto relevante dessa investigação indico a comunicação direta da pesquisadora e dos sujeitos de pesquisa. A comunicação é fundamental para a investigação na Epistemologia Qualitativa, é através do processo dialógico que o pesquisador pode se relacionar com o colaborador da pesquisa. Por isso mesmo, encontrei tensão no processo de comunicação com os jovens colaboradores, no movimento da pesquisa.

O pesquisador que se propõe a compreender pessoas falantes de LS, nesta perspectiva epistemológica que privilegia o contato direto e a dialogicidade deve fazer o contato direto com os sujeitos, sem a necessidade de intérprete que pode alterar a pergunta, uma vez que a subjetividade da intérprete está implicada no momento da ação interpretativa, por meio de suas escolhas lexicais (TAVARES-SANTOS, 2015a).

$\mathrm{Na}$ perspectiva epistemológica que busca um contato direto do pesquisador e colaborador é essencial uma comunicação que seja efetiva para os objetivos que se pretende alcançar. A participação de intérprete poderia comprometer a relação que se estabelece entre o pesquisador e o colaborador da pesquisa, como também ao interpretar a pergunta feita pelo pesquisador, a escolha de um sinal em detrimento de outro está constituída de aspectos de sua subjetividade. Pois para González Rey (2005) tanto a pergunta quanto a resposta estão carregadas pela subjetividade de quem questiona e de quem responde, e eu complementaria, também de quem interpreta.

Ainda que a interpretação fosse o mais próximo do proposto pelo pesquisador, uma comunicação direta entre o pesquisador e o colaborador permitiu compreender os aspectos subjetivos ali presentes e o contato "olho no olho" tornou a comunicação rica durante os encontros. 
Outro ponto a considerar em relação à peculiaridade da LS para a pesquisa em Epistemologia Qualitativa, diz respeito aos momentos informais de diálogo. Apesar de, na Epistemologia Qualitativa, os momentos informais serem considerados ricos para produção do conhecimento, com o uso das línguas de sinais isso pede um-certo cuidado. Como uma língua visual, por diversas vezes a pesquisadora ficou constrangida de, nesses momentos, explorar questões que pudessem ser entendidas por pessoas que estivessem distantes. No pátio da escola, sucessivos diálogos poderiam ter sido aprofundados, contudo a língua visual e a condição emocional da pesquisadora impediram essas intervenções. A professora surda, porém, parece não ter se intimidado com essas situações. Em uma ocasião, quando falávamos sobre assuntos femininos e abusos no ônibus e no metrô, rapidamente advertiu um estudante que, de longe, acompanhava a conversa. Lembrou as regras de educação estabelecidas quanto ao uso da língua de sinais e a participação em diálogos de outras pessoas ou grupos.

A adoção de um processo de comunicação em detrimento de outro ou mesmo o uso da língua oral ou da língua gesto-visual em momentos diferentes pelo Surdo ocorre a partir dos “espaços convivenciais cotidianos" (MADEIRA-COELHO, 2011, p.158), das oportunidades linguísticas e emocionais que ele vivencia no decorrer da sua vida, do modo como a família subjetiva a surdez, enfim, do modo como o próprio Surdo configura sentidos subjetivos produzidos em situações cotidianas de processos de comunicação tensionados, assim como, do modo que se constitui subjetivamente, uma vez que a comunicação é um processo complexo e sistêmico do qual participam aspectos subjetivos produzidos nos mais diversas situações e contextos.

Vigotsky postula que "a criança surda é, antes de tudo, uma criança e depois, um surdo. Isto significa que, em primeiro lugar, a criança deve crescer, desenvolver-se e educar-se seguindo os interesses, inclinações e leis comuns da infância, e no curso do desenvolvimento, ir assimilando a linguagem" (Vigotsky, 1997, p. 230), para além de sua constituição biológica que possui características peculiares ao modo de se relacionar socialmente. Pelo paradigma que orienta esse trabalho pode-se parafrasear o autor concluindo que a investigação contribuiu para compreender a pessoa surda como pessoa em seus aspectos históricos, emocionais e culturais, em seu caráter holístico em sua constituição complexa e integral.

Concluo ainda, que a pesquisa constitui-se como espaço relacional favorável ao desenvolvimento da pesquisadora e dos sujeitos colaboradores da pesquisa.

Considera-se esta pesquisa como relevante, pois: poderá contribuir para a reflexão sobre os processos de subjetivação de Surdos com possibilidade de reverberar em mudança no olhar sobre a aprendizagem desses estudantes e na organização criativa do trabalho docente; 
contribuir para minimizar uma lacuna na produção acadêmica que contemple os aspectos subjetivos dos Surdos; facilitar o enriquecimento de políticas públicas relacionados à pratica de educação bilíngue e permitir a reflexão sobre aspectos subjetivos de escolas para surdos. 


\section{REFERÊNCIAS}

AFONSO, C. Reflexões sobre a surdez: A Educação de Surdos. Vila Nova Gaia: Gailivros, 2007.

ALBRES, N. D. A.; LACERDA, C. B. F. D. A produção de conhecimento científico pela lente histórico-cultural e enunciativo-discursiva: contribuições contemporâneas. In: ANDREIS-WITKOSKI, S.; FILIETAZ, M. R. P. Educação de surdos em debate. Curitiba: UTFPR, 2014. Cap. 1.

BARROS, D. P. D. A comunicação humana. In: MUSSALIM, F.; BENTES, A. C. Instrodução à Linguística: domínios e fronteiras. São Paulo: Cortez, v. 02, 2001.

BARTHOLO, R. Alteridade e preconceito. In: TUNES, E.; BARTHOLO, R. Nos limites da ação: preconceito, inclusão e deficiência. São Carlos: Edufscar, 2007.

BAUMAN, H.- D. L.; MURRAY, J. J. Estudos surdos no século 21:"Deaf-gain" e o futuro da diversidade humana. In: ANDREIS-WITKOSKI, S.; FILIETAZ, M. R. P. Educação de Surdos em debate. Curitiba: UTFPR, 2014. p. 67-92. Disponivel em:

<http://www.utfpr.edu.br/editora/catalogo/educacao_surdos_em_debate.pdf>. Acesso em: 13 set. 2015.

BERTHIER. Abaixo-assinado Direito pode Libras ou falar! Direito meu! Brasília, DF: [s.n.], 2013.

BEZERRA, M. D. S. Dificuldades de aprendizagem e subjetividade: para além das representações hegemônicas do aprender. Brasília- DF: Dissertação de Mestrado (Faculdade de Educação), 2014.

BISOL, C.; SPERB, T. M. Discursos sobre a surdez: Deficiência, Diferença Singularidade e Construção de sentidos. Psicologia: Teoria e Pesquisa, Brasília, 2010.

BITTENCOURT, Z. Z. L. D. C. et al. Surdez, redes sociais e proteção social. Ciência Coletiva, 2011.

BLIKSTEIN, I. Técnicas de comunicação escrita. São Paulo: Contexto, 2016.

BRASIL. Subsídios para a Política Linguística de Educação Bilingue - Língua Brasileira de Sinais e Língua Portuguesa. Grupo de Trabalho, conforme portaria 1.060/2013 e 91/2013. Brasília, DF. 2014.

BRASIL, MINISTÉRIO DA EDUCAÇÃO. Principais Indicadores da Educação de Pessoas com Deficiência. MEC/INEP. Brasília. 2015.

BRASIL, MINISTÉRIO DA EDUCAÇÃO. Mapa de inovação e criatividade na educação básica. Brasília. 2016.

BUZAR, E. A. S. Da libras ao silêncio: implicações do olhar winnicottiano a sujeitos surdos em sofrimento psíquico grave. Brasília: UnB. Faculdade de Psicologia, 2015.

CHAMBERLAIN, C.; MAYBERRY, R. American Sing Lanaguage Syntactic e Narrative Comprehension in Skilled and Less Skilled Readers: Bilingual and Bimodal Evidence for the linguistic Basic of Reading. Applied Psycholinguistic, p. 367-388, 2008. 
COELHO, O. Um copo vazio está cheio de ar: Assim é a surdez. Porto: Livpsic, 2010.

COELHO, O.; CORTES, S. Surdos Isolados, Cidadania, Identidade e Iliteracia. In: COELHO, O.; KLEIN, M. Cartografias da surdez. Comunidades, Línguas, Práticas e Pedagogia. Porto, Portugal: Livpsic, 2013. p. 389-406.

COELHO, O.; GOMES, M. D. C. C. E. Surdos e ouvintes, mais que uma língua em cada língua. In: BIZARRO, R. Eu e o Outro: Estudos multidisciplinares sobre identidade(s), diversidade e práticas interculturais. Porto: Flup, 2007. p. 376-384.

COELHO, O.; GOMES, M. D. C.; CABRAL, E. Surdos e Ouvintes, mais que uma língua em cada língua. In: BIZARRO, R. Eu e o Outro. Estudos multidisciplinares sobre Identidade(s), Diversidade(s) e Práticas Culturais. Perafita: Areal Editores, 2007. p. 376384.

COLIN, D. Psicología del niño sordo. Barcelona: toray-masson, 1980.

CORDOVA, B. C.; TACCA, M. C. V. R. O Intérprete de Língua de Sinais e a Ação Pedagógica no Processo de Aprendizagem do sujeito Surdo. In: MITJÁNS MARTINEZ, A.; TACCA, M. C. V. R. Possibilidades de Aprendizagem: ações pédagógicas para alunos com dificuldade e deficiência. Campinas-SP: Alínea, 2011.

DISTRITO FEDERAL. Lei 4075 de dezembro de 2007, Brasília, 28 dezembro 2007.

DISTRITO FEDERAL. Plano de carreira dos professores da SEDF, Brasília, maio 2013.

DISTRITO FEDERAL. Projeto Político Pedagógico da Escola Pública integral Bilíngue Libras Português escrito. Brasília: SEDF, 2015.

DISTRITO FEDERAL. Lei 5.016 de 11 de janeiro de 2013, Brasília, 10 janeiro 2016. Disponivel em: <http://www.sinprodf.org.br/wp-content/uploads/2013/06/lei-n\%C2\%BA5016-de-11-de-janeiro-de-2013.pdf $>$.

DORZIAT, A. O outro da educação: Pensando a surdez com base nos temas Identidade/Diferença, Currículo e Inclusão. Petrópolis, RJ: Vozes, 2009.

EMERTON, G. Marginality, Biculturalism, and Social Identitaty of Deaf People. In:

PARANIS, I. Cultural and language diversity and the deaf experience. New York, USA: Cambridge University Press, 1998. p. 136-145.

ESTELITA, M. Escrita das Línguas de Sinais. In: QUADROS, R.; PERLIN, G. Estudos Surdos. Petrópolis, RJ: Arara Azul, 2007. p. 212-237.

FERNANDES, E. E. Q. R. M. Surdez e Bilinguismo. Porto Alegre: Mediação, 2005.

FERREIRA, A. B. D. H. Novo dicionário Aurélio da Língua Portuguesa. Curitiba: Positivo, 2009.

FRANCO, T. Bullying contra surdos: A manifestação silenciosa da resiliência. Curitiba: Appris, 2014.

FREIRE, P. Extensão ou comunicação. 8 $^{\text {a }}$. ed. Rio de Janeiro: Paz e Terra, 1983. 
GESSER, A. Libras: que língua é essa? Crenças e preconceitos em torno da língua de sinais e da realidade surda. São Paulo: Parábola, 2009.

GOLDFELD, M. A criança surda: linguagens e cognição numa perspectiva sociointeracionista. São Paulo: Plexus, 2002.

GOLDIN-MEADOW, $\mathrm{S}$. The resilience of language: what gesture creation in deaf children can tell us about how all children learn language. New York: Psychology Press, 2003.

GOMES, M. D. C. Lugares e Representações do Outro: a surdez como diferença. Porto: CIIE- Livpsic, 2010.

GOMES, M. D. C. F. A reconfiguração política da surdez: entre os discursos identitários e os discursos de regulação. Porto, Portugal: Universidade do Porto, Tese de doutorado, 2012.

GOMES, M. D. C.; CABRAL, E.; COELHO, O. Diferentes somos todos: A educação de surdos como mediação cultural. In: BIZARRO, R. A escola e a diversidade cultural, como abordar. Porto: Portugal: Areal Editores, 2006. p. 46-58.

GONZÁLEZ REY, F. Psicología: principios e categorías. La Habana: Editorial de Ciências Sociales, 1989.

GONZÁLEZ REY, F. O sujeito, a subjetividade e o outro na dialética complexa do desenvolvimento humano. In: SIMÃO, L. M.; MITJÁNS MARTINÉZ, A. O outro no desenvolvimento humano. São Paulo: Thomson, 2004a.

GONZÁLEZ REY, F. Subjectivity in comunication: Development of personality. In: BRANCO, Â. U.; VALSINER, J. Rede de comunication and metacommunication in human development. [S.1.]: Connectcut, 2004b.

GONZÁLEZ REY, F. O valor heurístico da Subjetividade na Investigação Psicológica. In: GONZÁlEZ REY, F. Subjetividade, Complexidade e Pesquisa em Psicologia. São Paulo: Pioneira Thomson, 2005a.

GONZÁLEZ REY, F. A violência: gênese, manipulação e ocultamento social. In: SPINK, M. A. J.; SPINK, P. Práticas cotidianas e a naturalização da desigualdade: uma semana de notícias nos jornais. [S.1.]: Cortez, 2006.

GONZÁLEZ REY, F. Psicoterapia, Subjetividade e Pós- Modernidade: Uma aproximação histórico-cultural. São Paulo: Thomson, 2007.

GONZÁLEZ REY, F. Os aspectos subjetivos no desenvolvimento de crianças com necessidades especiais: além dos limites concretos do defeito. In: MITJÁNS MARTINÉZ, A.; TACCA, C. V. R. Possibilidades de aprendizagem: ações pedagógicas para alunos com dificuldade e deficiência. Campinas, SP: Alínea, 2011a.

GONZÁLEZ REY, F. O pensamento de Vigotsky: contradições, desdobramentos e desenvolvimento. São Paulo: Hucitec, 2012a.

GONZÁLEZ REY, F. O social na psicologia e a psicologia social: a emergência do sujeito. $3^{\mathrm{a}}$ edição. ed. Petrópolis- RJ: Vozes, 2012b. 
GONZÁLEZ REY, F. O que oculta o silêncio epistemológico da Psicologia? Pesquisas e Práticas Psicossociais, São Jõao del-Rei, Rio de Janeiro, p. 20-34, 2013.

GONZÁLEZ REY, F. Idéias e modelos teóricos na pesquisa construtivo-interpretativa. In: MARTINEZ, A. M.; NEUBERN, M.; MORI, V. D. Subjetividade contemporânea: discussões epistemológicas e metodológicas. Campinas, SP: Alínea, 2014.

GONZÁLEZ REY, F. A vida e a obra de Boris Federovich Lomov: o "giro" da psicologia soviética nos anos setenta do século XX. In: PUENTES, R. V.; LONGAREZI, A. M. Ensino desenvolvimental: vida, pensamento e obra dos principais representantes russos. Uberlândia, MG: UDUFU, v. II, 2016. p. 239-266.

GONZÁLEZ REY, F. L. Comunicación, personalidad e desarrollo. Habana: Pueblo y Educación, 1995.

GONZÁLEZ REY, F. L. Psicologia y lenguaje el lugar de los significados en la vida psiquica. Saberes, 2001. ISSN 01.

GONZÁleZ REY, F. L. Pesquisa Qualitativa em Psicologia. São Paulo: Thomson, 2002.

GONZÁLEZ REY, F. L. Sujeito e subjetividade: uma aproximação histórico-cultural. São Paulo: Thomson, 2003.

GONZÁLEZ REY, F. L. Pesquisa Qualitativa e Subjetividade: os processos de construção da informação. São Paulo: Pioneira Thomson, 2005b.

GONZÁLEZ REY, F. L. Subjetividade e Saúde: superando a clínica da patologia. São Paulo: Cortez, 2011b.

GONZÁLEZ REY, F.; MITJÁNS MARTINEZ, A. La personalidad: su educación y desarrolo. Havana: Pueblo y Educaión , 1989.

GOZÁLEZ REY, F. Psocología; princípios y categorías. La Habana: Publo y Educación, 1985.

GUARINELLO, A. C. O papel do outro na escrita de sujeitos surdos. São Paulo: Plexus, 2007.

GURGEL, I. V. Letramento na escrita da luz: a vez e a voz do olhar surdo. Brasília, DF: Universidade de Brasília, 2015.

INES, I. N. D. E. D. S. Atas do Congresso de Milão- 1880. Rio de Janeiro: INES, 2011.

JAKOBSON, R. Linguística e Comunicação. São Paulo: Cultrix, 1969.

KELMAN, C. A. Significação e Aprendizagem do aluno surdo. In: MITJÁNS MARTINEZ, A.; TACCA, M. C. V. R. Possibilidades de Aprendizagem: ações pedagógicas para alunos com dificuldade e deficiência. Campinas, SP: Alínea, 2011. p. 175-207.

KELMAN, C. A.; BUZAR, E. A. S. A (in)visibiidade do aluno surdo em classes inclusivas: discussões e reflexões. Espaço aberto, 2012. 
KELMAN, C. A.; MARTINS. Peculiaridades da significação no letramento de adultos surdos. In: ORRÚ, S. E. Estudantes com necessidades especiais: singularidades e desafios na prática pedagógica inclusiva. Rio de Janeiro: Wak Editora, 2012.

KIRKPATRICK, D. O efeito Facebook: os bastidores da empresa que conecta o mundo. Tradução de Maria Lúcia de Oliveira. Rio de Janeiro: Intríseca, 2011.

LABORIT, E. O vôo da gaivota. Paris: E, 1994.

LACERDA, C. B. F. Um pouco da história das diferentes abordagens na educação de surdos. Caderno CEDES, 1998.

LADD, P. Em busca da surdidade1: Colonização dos surdos. Lisboa: Surd Universo, 2013.

LARROSA, J.; SKLIAR, C. Babilônios somos. a modo de apresentação. In: LARROSA, J.; SKLIAR, C. Habitantes de Babel: Política e poéticas da diferença. Belo Horizonte: Autêntica, 2011.p. 07-30.

LEBEDEFF, T. B.; ROSA, F. S. Quando eu era criança sinalizava assim: memórias e registros de um sistema de sinais caseiros convencionados na infância de um casal de irmãos surdos. In: COELHO, O.; KLEIN, M. Cartografias da surdez. Comunidades, línguas, práticas e pedagogia. Porto, Portugal: Livpsic, 2013. p. 99-113.

LOIZOS, P. Vídeo, filme e fotografias como documentos de pesquisa. In: BAUER, M. W.; GASKELL, G. Pesquisa Qualitativa com texto, imagem e som. Petrópolis- RJ: Vozes, 2002.

LOPES, C.; COELHO, O. Negando a incomunicabilidade surda:A importância das interações comunicacionais em contexto familiar. In: ORQUÍDEA, C.; KLEIN, M. Cartografias da Surdez. Comunidades, Línguas, Práticas e Pedagogia. Porto, Portugal: Livpsic, 2013. p. 451-466.

LULKIN, S. A. O discurso moderno na educação dos surdos: práticas de controle do corpo e expressão cultural amordaçada. In: SKLIAR, C. A surdez: um olhar sobre as diferenças. Porto Alegre: Mediação, 1998.

MACHADO, R. Depoimento pessoal, Brasília, DF, Junho 2015.

MADEIRA-COELHO, C. Linguagem, fala e audição nos processos de aprendizagem. In: MITJÁNS MARTINÉZ, A.; TACCA, C. V. R. Possibiliddades de Aprendizagem: Ações pedagógicas para alunos com dificuldade e deficiência. Campinas, SP: Alínea, 2011.

MADEIRA-COELHO, C. M. Um olhar sobre a relação sujeito-linguagem: a subjetividade e os transtornos de comunicação. Brasília, DF: Tese de Doutorado. Instituto de Psicologia. Universidade de Brasília, 2004.

MADEIRA-COELHO, C. M. Sujeito, Linguagem e Aprendizagem. In: MARTINÈZ, A. M.; TACCA, M. C. V. R. A complexidade da Aprendizagem: destaque ao Ensino Superior. Campinas, São Paulo: Alínea, 2009.

MARQUES DE MELO, J. Comunicação social: teoria e pesquisa. Petrópolis: Vozes, 1975. 
MARTINS, C. A. A cultura surda na escola. In: PERLIN, G.; STUMPF, M. Um olhar sobre nós surdos: leituras contemporâneas. Curitiba: CRV, 2012.

MARTINS, L. M. B. A significação no desenvolvimento de surdos adultos em processo de aquisição da primeira língua. Brasília: Universidade de Brasília, 2010.

MARTINS, L. M. B. A prática pedagógica no letramento bilíngue de jovens adultos surdos. Brasília: Tese de doutorado. Faculdade de Educação. Universidade de Brasília, 2015.

MITJÁNS MARTINEZ, A. O outro e sua significação para a criatividade: implicações educacionais. In: MITJÁNS MARTINEZ, A.; SIMÃO, L. M. O outro no desenvolvimento humano. São Paulo: Pioneira Thomson, 2004. p. 77-99.

MITJÁNS MARTINEZ, A. A Teoria da Subjetividade de González Rey: Uma expressão do Paradigma da Complexidade na Psicologia. In: GONZÁLEZ REY, F. Subjetividade, Complexidade e Pesquisa em Psicologia. São Paulo: Thomson, 2005. p. 1-26.

MITJÁNS MARTINEZ, A. Um dos desafios da Epistemologia Qualitativa: a criatividade do pesquisador. In: MITJÁNS MARTÍNEZ, A.; NEUBERN, M.; MORI, V. D. Subjetividade Contemporânea: discussões epistemológicas e metodológicas. Campinas-SP: Alínea, 2014. Cap. 3, p. 61-86.

MITJÁNS MARTINEZ, A. L.I. Bozhovich: vida, pensamento e obra. In: PUENTES, R. V.; LOGARENZI, A. M. Ensino desenvolvimental: vida, pensamento e obra dos principais autores russos. Uberlândia, MG: [s.n.], v. II, 2016. p. 165-196.

MITJÁNS MARTINEZ, A.; NEUBERN, M.; MORI, V. D. Subjetividade Contemporânea: discussões epistemológicas e metodológicas. Campinas- SP: Alínea, 2014.

OLIVEIRA, M. M. Como fazer pesquisa qualitativa. $3^{\text {a }}$ Edição revista e ampliada. ed. Petrópolis, RJ: Vozes, 2010.

ORSONI, L. C. A. M. A produção de sentidos da surdez e de filhos surdos. Goiânia: Universidade Católica de Góias, 2007.

PADDEN, C.; HUMPHRIES, T. Deaf in américa: voices from a culture. Cambridge: Harvad University, 2000.

PERES, V. L. A. O estudo da subjetividade na família: Desafios Metodológicos. In: GONZÀLEZ REY, F. L. Subjetividade, Complexidade e Pesquisa em Pscologia. [S.l.]: Pioneira Thomson, 2005.

PERLIN, G. Cultura e educação bilíngue no pulsar das identidades surdas contemporâneas. In: ANDREIS-WITKOSKI, S.; FILIETAZ, M. R. P. Educação de surdos em debate. Curitiba: UTFPR, 2014.

PETITTO, L. A.; MARENTETTE, P. Babbling in the manual mode: Evidence for the ontogeny of the language. [S.1.]: Science, 1991.

QUADROS, R. M. D.; KARNOPP, L. B. Língua de Sinais brasileira: Estudos linguísticos. Porto Alegre, RS: Artmed, 2004. 
RINALDI, G. Etiologia (causas) e prevenção da surdez. In: BRASIL, S. D. E. E. M. D. E. Deficiência Auditiva. Brasília: MEC/SEESP, v. I, 1997.

ROCHA, S. M. D. Libras no contexto da educação dos surdos e na interpretação de Língua de sinais- CONALIBRAS, Uberlândia, MG, 2015.

ROSA, G. A. M. Facebook: negociações de identidades: medo de expor e subjetividade. Brasília: Dissertação de Mestrado. Universidade Católica de Brasília, 2012.

ROSSATO, M.; MARTINS, L. R. R.; MITJÁNS-MARTINEZ, A. A construção do cenário social da pesquisa no contexto da Epistemologia Qualitativa. In: MITJÁNS-MARTINEZ, A.; NEUBERN, M.; MORI, V. Subjetividade Contemporânea: discussões epistemológicas e metodológicas. Campinas- SP: Alínea, 2014.

ROSSATO, M.; MITJÁNS MARTINEZ, A. A superação das dificuldades de aprendizagem e as mudanças na subjetividade. In: MITJÁNS MARTINEZ, A.; TACCA, M. C. V.

Possibilidades de aprendizagem: ações pedagógicas para alunos com dificuldades e deficiência. Campinas, SP: Alínea, 2011.

SACKS, O. Vendo Vozes. São Paulo: Companhia das Letras, 1998.

SANTANA, A. P. Surdez e linguagem: Aspectos e implicações neurolinguísticas. São Paulo: Plexus, 2007.

SAUSSURE, F. Curso de Linguística geral. São Paulo: Cultrix, 1969.

SCHALLENBERGER, A. Comunidades surdas nas redes sociais: pela resistência e perpetuação da diferença através do humor. In: PERLIN, G.; STUMPF, M. Um olhar sobre nós surdos: leituras contemporânea. Curitiba: CRV, 2012.

SEDF. Orientação Pedagógica: educação especial. Brasília, DF: [s.n.], 2010.

SEDF. Estratégia de Matrículas. Brasília: Rede Pública de Ensino do Distrito Federal, 2016.

SILVA, N. L. P.; DESSEN, M. A. Deficiência Mental e Família: Implicações para o Desenvolvimento da Criança. Psicologia: Teoria e Pesquisa, p. 133-141, 2001.

SILVA, R. Língua Gestual e Bilínguismo na Educação da Criança Surda. In: COELHO, O. Um copo vazio está cheio de ar: Assim é a surdez. Porto: Livpsic, 2010. p. 101-143.

SKLIAR, C. Abordagens sócio-antropológicas em Educação Especial. In: SKLIAR, C.

Educação e Exclusão: Abordagens Socio-antopológicas em Educação Especial. Porto alegre: Mediação, 1997a. p. 8-20.

SKLIAR, C. Uma perspectiva sócio-histórica sobre a psicologia e a educação dos surdos. In: SKLIAR, C. Educação e exclusão: Abordagens socioantropológicas em Educação Especial. Porto Alegre: Mediação, 1997b. p. 97-140.

SKLIAR, C. A surdez: um olhar sobre as diferenças. In: SKLIAR, C. A surdez: um olhar sobre as diferenças. Porto Alegre: Mediação, 1998a. p. 7-32. 
SKLIAR, C. Os estudos surdos em educação problematizando a normalidade. In: SKLIAR, C. A surdez: um olhar sobre as diferenças. Porto Alegre: Mediação, 1998b.

SKLIAR, C. Pedagogia (improvável) da diferença e se o outro não estivesse aí? Rio de Janeiro: DP\&A, 2003.

SKLIAR, C. Experiências com a palavra: Notas sobre linguagem e diferença. Rio de Janeiro: Wak editora, 2012.

STROBEL, K. As imagens do outro sobre a cultura surda. Florianópolis: Ed da UFSC, 2009.

STROBEL, K. L. Os sobreviventes das políticas surdas: opressão da cultura e de seus valores linguísticos na educação. In: PERLIN, G.; STUMPF, M. Um olhar sobre nós surdos: Leituras contemporâneas. Curitiba, PR: CRV, 2012. p. 97-107.

STUMPF, M. R. Sistema Sign Writing: por uma escrita funcional para o surdo. In: THOMA, A. D. S.; LOPES, M. C. A invensão da surdez: Cultura, alteridade, identidade e diferença no campo da educação. Santa Crus do Sul: EDUNISC, 2004. p. 143-159.

STUMPF, M. R. Aprendizagem de Escrita de Língua de Sinais pelo Sistema Sign Writing: Língua de Sinais no papel e no computador. Porto Alegre: Tese de doutorado UFRGS, 2005.

TACCA, M. C. V. R. Além de professor e de aluno: a alteridade nos processos de aprendizagem. In: SIMÃO, L. M.; MITJÁNS MARTÍNEZ, A. O outro no desenvolvimento humano: diálogos para a pesquisa e a prática profissional em psicologia. São Paulo: Pioneira Thomson, 2004.

TACCA, M. C. V. R. Relações sociais na escola e desenvolvimento da subjetividade. In: MALUF, M. H. Aprendizagem: Tramas do conhecimento, do saber e da subjetividade. Petrópolis, Rj: Vozes, 2006.

TAVARES-SANTOS, V. Pais ouvintes X Filhos surdos. Existe vínculo afetivo? Brasília, DF: Faculdade de Selviria - FAS. Especialização Lato Sensu Psicopedagogia Institucional, 2004.

TAVARES-SANTOS, V.; MADEIRA-COELHO, C. M. Significados e sentidos sobre a formação de uma cidade: o olhar de estudantes surdos e seus familiares. ISCAR - Brasil. São Paulo: [s.n.]. 2014.

TAVARES-SANTOS, V.; MADEIRA-COELHO, C. M. Sentidos subjetivos da relação entre um intérprete educacional e estudantes surdos em constextos escolares. Anais do XII Congresso Nacional de Educação - EDUCERE, 2015a.

TAVARES-SANTOS, V.; MADEIRA-COELHO, C. M. A singularidade do aluno surdo subjetivação dos usos da linguagem e escola. CD dos anais do Congresso Nacional de Libras, Uberlândia, novembro 2015b.

VIADER, M. D. P. F. La comunicación de los niños sordos: interacción comunicativa padres-hijos. Barcelona: Confederación Nacional de Sordos de España, 1996. 
VIGOTSKY, L. Pensamiento y habla. Buenos Aires: Colihue, 2007.

VIGOTSKY, L. S. Obras Ecogidas: Fundamentos da Defectologia. Madrid: Visor Dis, 1997.

VILHALVA, S. Índios surdos: mapeamento das línguas de sinais do Mato Grosso do Sul. Petrópolis: Arara Azul, 2012.

WATZLAWICK, P.; BEAVIN, J. H.; JACKSON, D. D. Pragmática da Comunicação: um estudo dos padrões, patologias e paradoxos da interação. Tradução de Álvaro Cabral. São Paulo: Cultrix, 1973.

ZILIO, V. M. A língua surda. In: LOPES, M. C. Cultura surda e Libras. Rio Grande do Sul: UNISINOS, 2012. Disponivel em:

<https://www.passeidireto.com/arquivo/10982080/335_livro_da_disciplina_cultura_surda_ e_libraspdf $>$. 


\section{APÊNDICE I - COMPLEMENTO DE FRASES PARA O ALUNO:}

1) Eu sou:

2) Na escola me sinto:

3) Os professores podem:

4) Gosto quando:

5) Não gosto:

6) Me comunico melhor:

7) Aprendo melhor:

8) Encontro meus amigos:

9) Oralismo para mim:

10) Os meus professores:

11) Sinto falta:

12) O que eu gostaria:

13) Para mim estudar é:

14) Minha família:

15) No futuro eu:

16) Eu desejo:

17) Ser feliz é:

18) Na minha casa: 
APÊNDICE II - ATIVIDADES
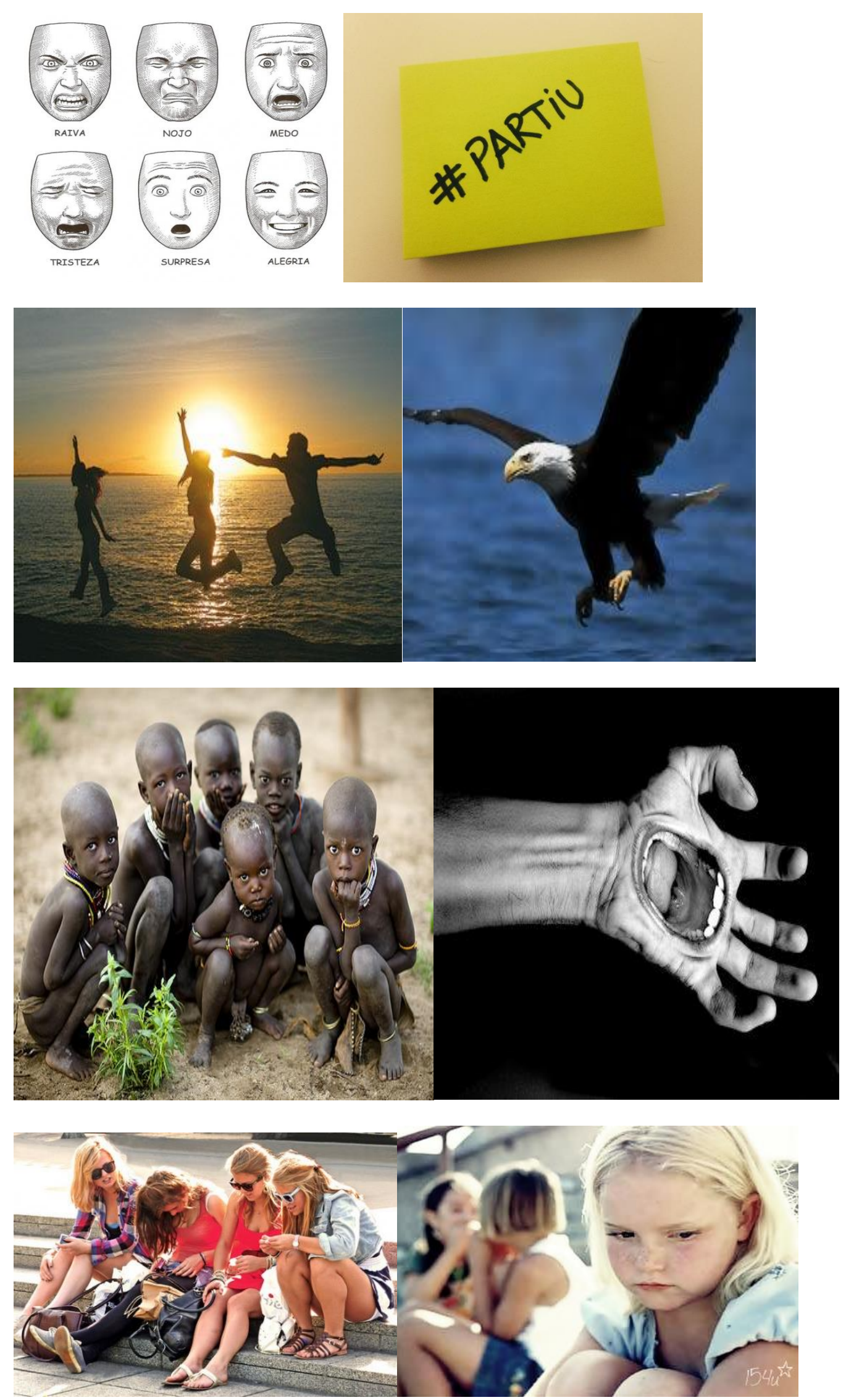

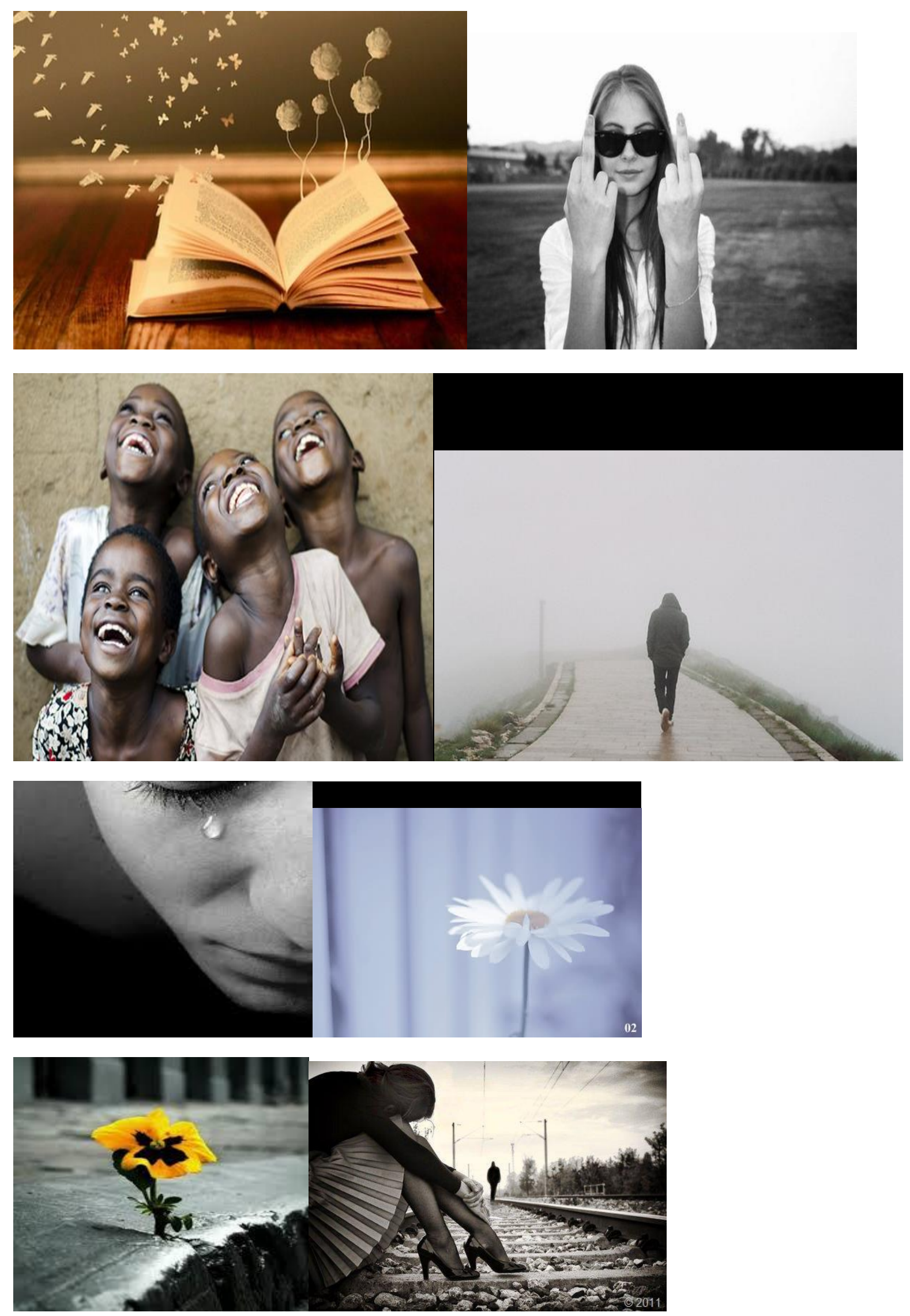

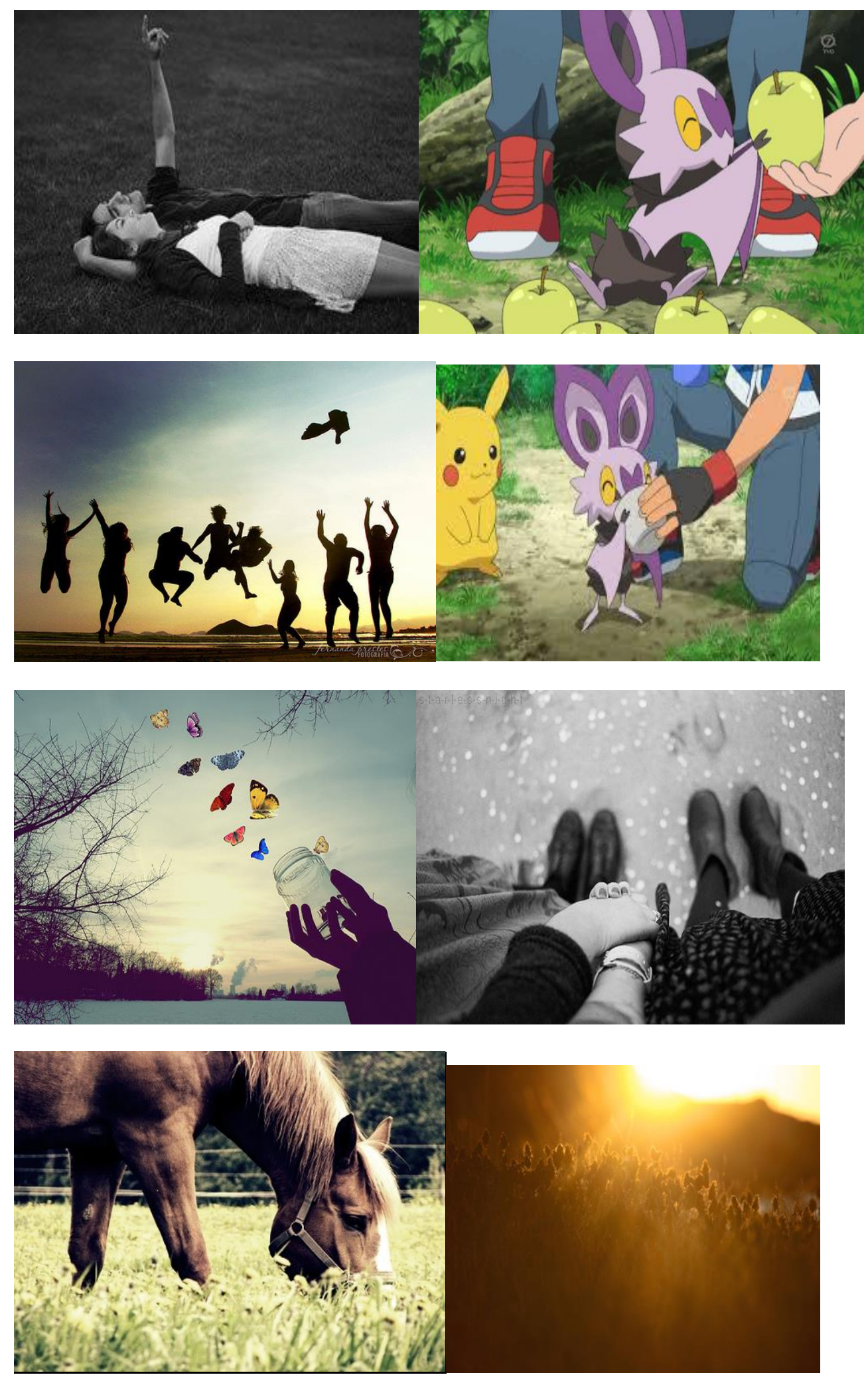

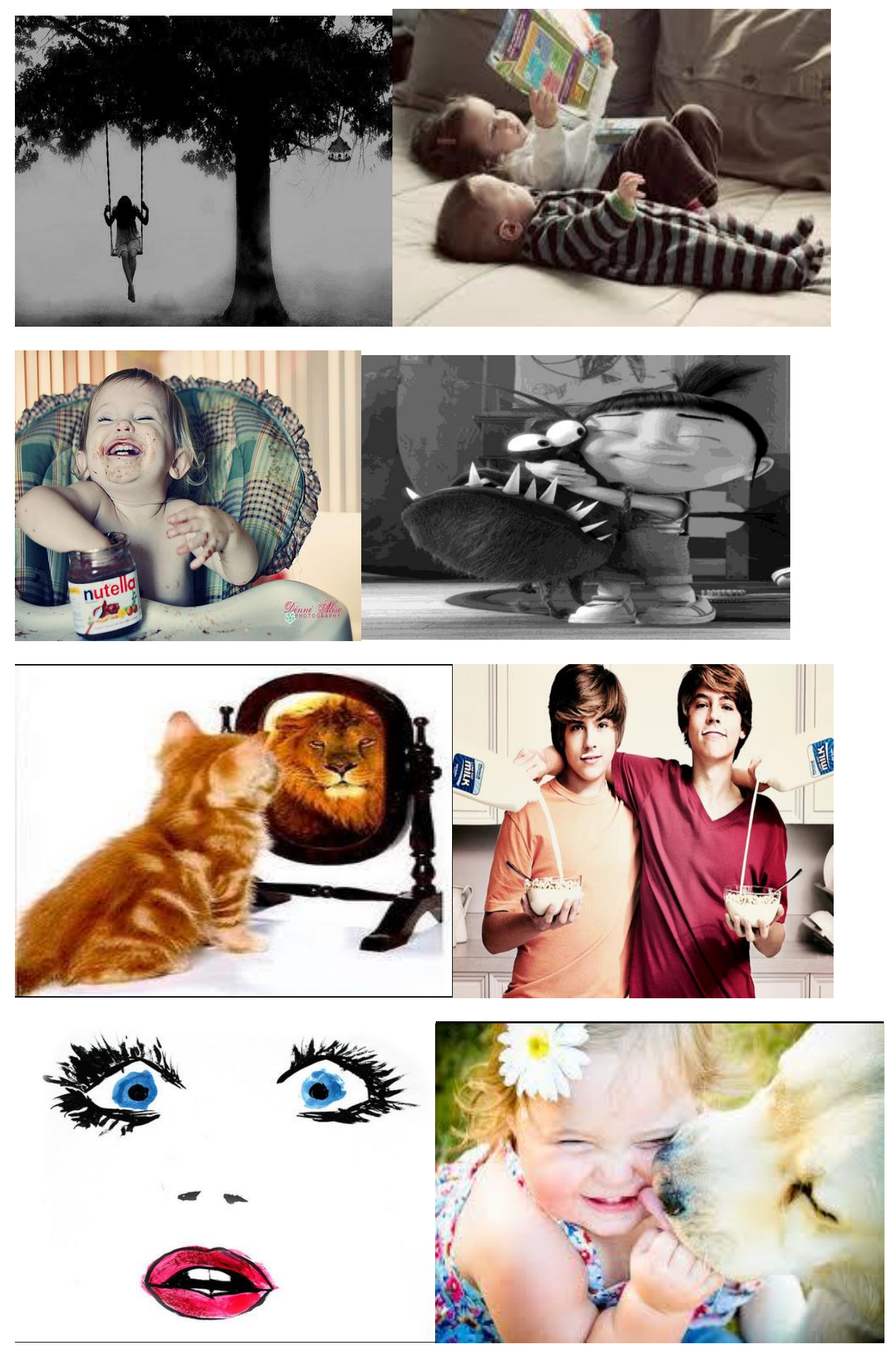

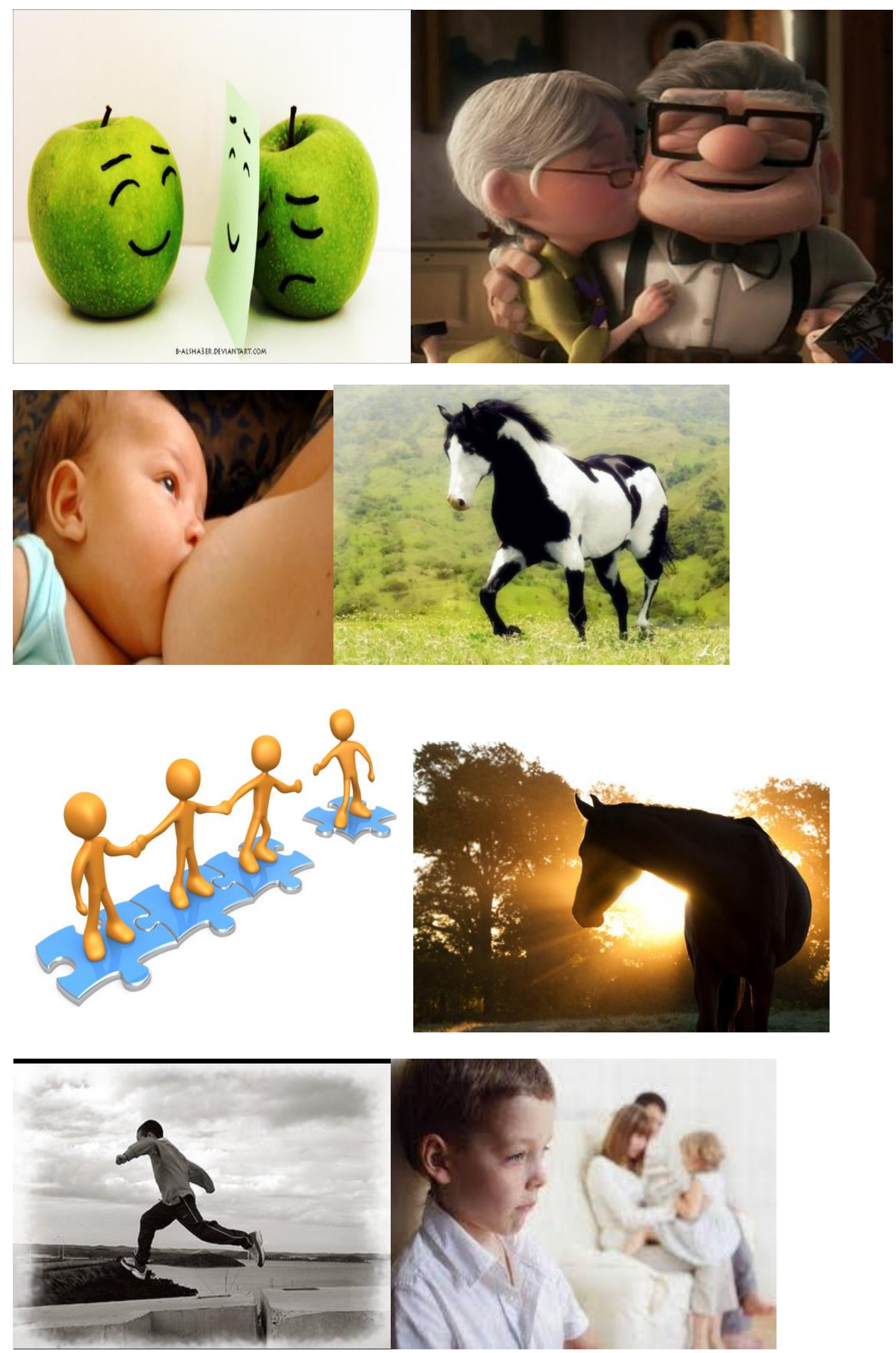

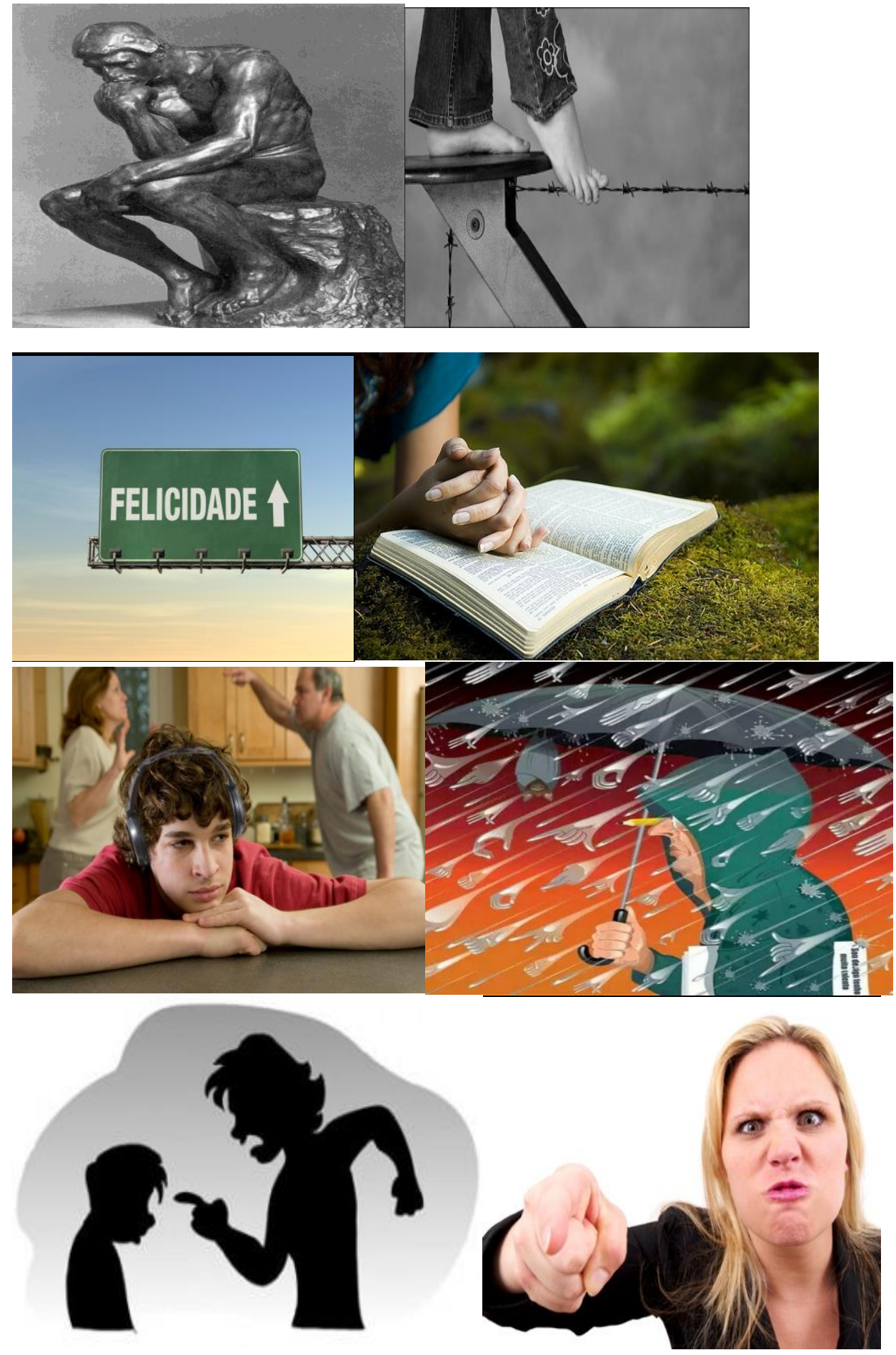

Utilize as gravuras para representar:

(1) [VOCÊ HOJE]:

(2) [FAMÍLIA]:

(3) $[\operatorname{IRMÃO}(\tilde{\mathrm{A}})]$ :

(4) $[\mathrm{CASA}]$ :

(5) [ESCOLA]:

(6) [COMUNICAÇÃO]:

(7) [AMIZADE]: 
(8) [CONVERSAR]: 


\section{APÊNDICE IV - SESSÕES DE OBSERVAÇÃO}

Quadro 1 - Sessões de observação ou encontro com os sujeitos da pesquisa

\begin{tabular}{|c|c|c|c|c|}
\hline \multirow{6}{*}{2014} & Data & Horário & Subtotal & Observação \\
\hline & $17 / 10$ & $7: 15$ ás 8:55 & $1: 40 \mathrm{~h}$ & \multirow{6}{*}{$\begin{array}{l}\text { Os encontros foram todos } \\
\text { realizados em escola } \\
\text { pública onde os estudantes } \\
\text { cursavam o } 9^{\circ} \text { ano. }\end{array}$} \\
\hline & $24 / 10$ & $7: 15$ ás 8:55 & $1: 40 \mathrm{~h}$ & \\
\hline & $31 / 10$ & $7: 15$ ás 8:55 & $1: 40 \mathrm{~h}$ & \\
\hline & $14 / 11$ & $7: 15$ ás 8:55 & $1: 40 \mathrm{~h}$ & \\
\hline & $28 / 11$ & 7:15 ás 8:55 & $1: 40 \mathrm{~h}$ & \\
\hline Subtotal & 5 encontros & & $8: 30 \mathrm{~h}$ & \\
\hline \multirow{14}{*}{2015} & Data & $\begin{array}{l}\text { Horário da } \\
\text { observação }\end{array}$ & Subtotal & Observação \\
\hline & $16 / 06$ & 14h ás $16 \mathrm{~h}$ & $2 \mathrm{~h}$ & Turno vespertino \\
\hline & $18 / 06$ & $\begin{array}{l}14 \mathrm{~h} \text { ás } \\
16 \mathrm{~h} 20\end{array}$ & $2 \mathrm{~h} 20$ & Turno vespertino \\
\hline & $25 / 06$ & $\begin{array}{l}13 \mathrm{~h} \text { ás } \\
16 \mathrm{~h} 20\end{array}$ & $3 \mathrm{~h}$ & Turno vespertino \\
\hline & $02 / 07$ & $14 \mathrm{~h}$ ás $16 \mathrm{~h}$ & $2 \mathrm{~h}$ & Turno vespertino \\
\hline & $09 / 07$ & 14h ás $16 \mathrm{~h}$ & $2 \mathrm{~h}$ & Turno vespertino \\
\hline & $16 / 07$ & $8 \mathrm{~h}$ ás $12 \mathrm{~h}$ & $4 \mathrm{~h}$ & Observação de aula \\
\hline & $04 / 08$ & $8 \mathrm{~h}$ ás $12 \mathrm{~h}$ & $4 \mathrm{~h}$ & Observação de aula \\
\hline & $11 / 08$ & $\begin{array}{c}\text { 7h30 ás } \\
12 h 30\end{array}$ & $5 \mathrm{~h}$ & Observação de aula \\
\hline & $18 / 08$ & 7h30 ás $12 \mathrm{~h}$ & $4 \mathrm{~h} 50$ & Observação de aula \\
\hline & $20 / 08$ & $\begin{array}{c}\text { 7h30 ás } \\
14 h 30\end{array}$ & $7 \mathrm{~h}$ & $\begin{array}{c}\text { Observação de aula, } \\
\text { almoço e atividade } \\
\text { diversificada no vespertino }\end{array}$ \\
\hline & $25 / 08$ & $\begin{array}{l}\text { 7h30 ás } \\
11 \text { h30 }\end{array}$ & $4 \mathrm{~h}$ & Observação de aula \\
\hline & $01 / 09$ & $\begin{array}{l}\text { 7h30 ás } \\
12 \mathrm{~h} 30\end{array}$ & $5 \mathrm{~h}$ & Observação de aula \\
\hline & $03 / 09$ & $\begin{array}{c}7 \mathrm{~h} 30 \text { ás } \\
12 \mathrm{~h} 30\end{array}$ & $5 \mathrm{~h}$ & Observação de aula \\
\hline
\end{tabular}




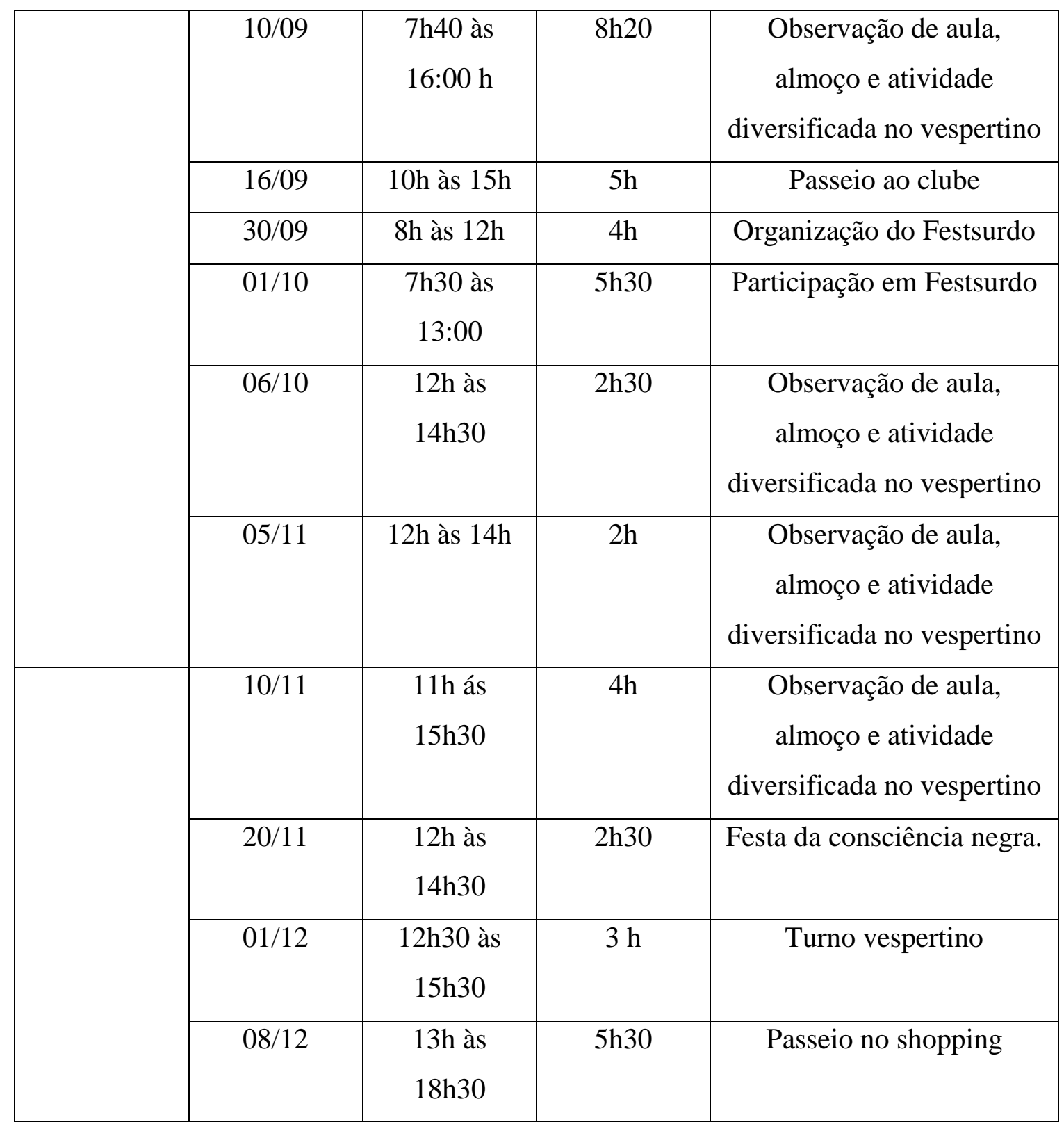

Fonte: Autora 